BNL 51189

\title{
$0,18,3$
}

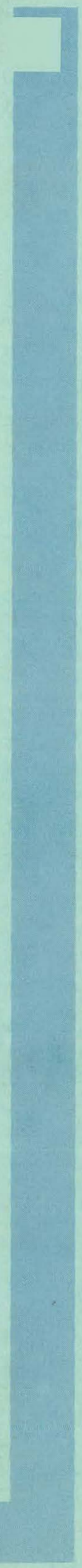

\section{GEOLOGICAL AND HYDROCHEMICAL SENSITIVITY OF THE EASTERN UNITED STATES TO ACID PRECIPITATION}

George R. Hendrey, James N. Galloway, Stephen A. Norton, Carl L. Schofield, Paul W. Shaffer, and Douglas A. Burns

March 1980

Prepared for the

UNITED STATES ENVIRONMENTAL PROTECTION AGENCY

ECOLOGICAL EFFECTS DIVISION

CORVALLIS ENVIRONMENTAL RESEARCH LABORATORY

UNDER EPA-DOE INTERAGENCY AGREEMENT 79-D-X0672

INITIATED $3 / 30 / 79$.

DEPARTMENT OF ENERGY AND ENVIRONMENT

BROOKHAVEN NATIONAL LABORATORY

UPTON, NEW YORK 11973

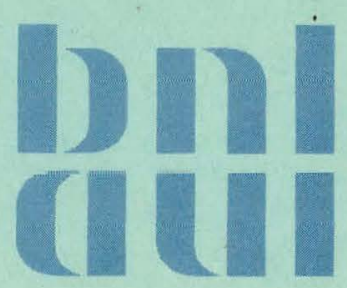




\section{DISCLAIMER}

This report was prepared as an account of work sponsored by an agency of the United States Government. Neither the United States Government nor any agency Thereof, nor any of their employees, makes any warranty, express or implied, or assumes any legal liability or responsibility for the accuracy, completeness, or usefulness of any information, apparatus, product, or process disclosed, or represents that its use would not infringe privately owned rights. Reference herein to any specific commercial product, process, or service by trade name, trademark, manufacturer, or otherwise does not necessarily constitute or imply its endorsement, recommendation, or favoring by the United States Government or any agency thereof. The views and opinions of authors expressed herein do not necessarily state or reflect those of the United States Government or any agency thereof. 


\section{DISCLAIMER}

Portions of this document may be illegible in electronic image products. Images are produced from the best available original document. 


\section{GEOLOGICAL AND HYDROCHEMICAL SENSITIVITY \\ OF THE EASTERN UNITED STATES \\ TO ACID PRECIPITATION}

by

George R. Hendrey, James N. Galloway,' Stephen A. Norton,"

Carl L. Schofield, Paul W. Shaffer,' and Douglas A. Burns,'

PREPARED FOR THE ECOLOGICAL EFFECTS DIVISION CORVALLIS ENVIRONMENTAL RESEARCH LABORATORY UNITED STATES ENVIRONMENTAL PROTECTION AGENCY UNDER EPA-DOE INTERAGENCY AGREEMENT 79-D-X0672 INITIATED 3/30/79 AND PUBLISHED AS EPA-600/3-80-024.

\footnotetext{
'Depurlimeiil of Eimvironmental Sciences, Univ. of Virginia, Charlottcsvillc, VI 22903

'Univ. of Maine, Orono, ME 04473

'Department of Natural Resources, Cornell Univ., Ithaca, NY 14854
}

\section{LAND AND FRESHWATER ENVIRONMENTAL SCIENCES GROUP DEPARTMENT OF ENERGY AND ENVIRONMENT BROOKHAVEN NATIONAL LABORATORY ASSOCIATED UNIVERSITIES, INC.}

UNDER CONTRACT NO. DE-ACO2-76CH00016 WITH THE UNITED STATES DEPARTMENT OF ENERGY 


\section{DISCLAIMER}

This book was prepared as an account of work sponsored by an agency of the United States Government. Neither the United States Government nor any agency therefof, nor any of thcir cmployces, makes any warranty, express ur implied, or assumes any legal liability or responsibility for the accuracy, completeness, or usefulness of any information, apparatue, produot, or proceos dioclosed, or represents that its use would not infringe privately owned rights. Reference herein to any specific commercial product, prucess, ur ser vice by trade name, trademark, manufacturer, or otherwisè, doès not necessarily constitute or imply its endorsement, recommendation, or favoring by the United States Government or any agency thereof. The views and opinions of authors expressed herein do not necessarily state or reflect those of the United States Guvernment or any ägency thereof.

Printed in the United States of America Available from

National Technical Information Service

U.S: Department of Commerce 5285 Port Royal Road Springfield, VA 22161

Price: Printed Copy $\$ 6.00$; Microfiche $\$ 3.00$ 
A new analysis of bedrock geology maps of the eastern U.S. constitutes a simple model for predicting areas which might be impacted by acid precipitation and it allows much greater resolution for detecting sensitivity than has previously been available for the region. Map accuracy has been verifled by examining current alkalinities and $\mathrm{pH}^{\prime} \mathrm{s}$ of waters in several test states, including Maine, New Hampshire, New York, Virginia and North Carolina. In regions predicted to be highly sensitive, alkalinities in upstream sites were generally low, <200 Heq/l. Many areas of the eastern U.S. are pinpointed in which some of the surface waters, especially upstream reaches, may be sensitive to acidification. Pre-1970 data were compared to post-1975 data, revealing marked declines in both alkalinity and $\mathrm{pH}$ of sensitive waters of two states tested, North Carolina, where $\mathrm{pH}$ and alkalinity have decreased in $80 \%$ of 38 streams $(\rho<.001)$ and New Hampshire, where $\mathrm{pH}$ in $90 \%$ of 49 streams and lakes has decreased $(\rho<.001)$ since 1949. These sites are predicted to be sensitive by the geological map on the basis of their earlier alkalinity values. Thus this mapping of sensitive areas is validated by the observed temporal trends. The map is to be improved by the addition of a soils component.

\section{ACKNOWLEDGMENTS}

The authors wish to thank Avis Newell for technical work in the field and laboratory; Fred Llotta, Susan Hall, Lisa Thurlow, Roland Dupuis and Marilyn Morrison for assistance in map preparation; and Ronnie Evans and Charlie Bores for data base management, data reduction, and computer graphics. We appreciate the generous cooperation and assistance by personnel of the Shenandoah National Park, the North Carolina Department of Inland Fisheries, and the New Hampshire Department of Fish and Game. 


\section{THIS PAGE \\ WAS INTENTIONALLY \\ LEFT BLANK}




\section{CONTENTS}

Acknowledgments . . . . . . . . . . . . . . . . . . ili Abstract ......................... . . . . . . . . . . .

I. Introduction ........................ 1

II. Preparation of Sensitive Areas Map . . . . . . . . . . . . 5

III. Verification of the Sensitive Areas Map . . . . . . . . . . . . . 24

IV. Temporal Trends in $\mathrm{pH}$ and Alkalinity:

Validation of the Sensitive Areas Map . . . . . . . . . 52

v. Impacts of Acidification on Aquatic Biota . . . . . . . . . 63

VI. Regional Assessment of Acidification Impacts

of Fish Population . . . . . . . . . . . . . . . 72

VII. References . . . . . . . . . . . . . . . . . 78

Appendix-I . . . . . . . . . . . . . . . . . . . 85

Appendix-II . . . . . . . . . . . . . . . . . . 86 


\section{LIST OF FIGURES}

Figure

II-la Unmodified tracing of all boundries of geologic formations shown on a portion of the North Carolina state geological map. Numbers refer to buffering classification.....

II-1b Boundaries of rock formations in North Carolina having comparable acid-neutralizing capacities. Numbers refer to buffering classification......................

III-1c Smoothing of geological contacts among areas of differing acid-neutralizing capacities shown in Figure II - $1 \mathrm{~b}$.

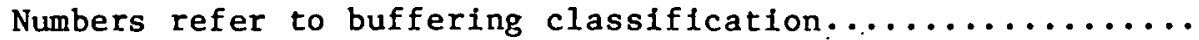

II-2a

Unmodified tracing of all boundaries of geologic formations shown on a portion of the New York state geological

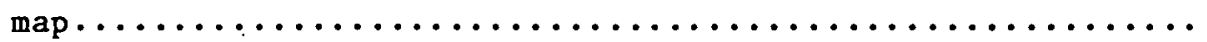

II-2b Boundaries of rock formations in New York having compar-

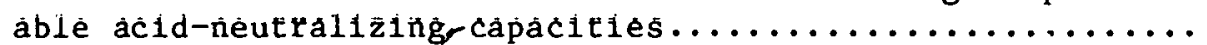

II-2c Swoothing of geologic contacts among areas of differing acid-neutralizing capacities in New York State. Areas of the Adirondack Mountains, shown in Figure II - $2 b$, are located in the center of the northeastern third of the state. Numbers refer to buffering classification..........

II-3a Unmodified tracing of all boundaries of geologic formations shown on a portion of the Tennessee state geologic map in a region of deridritic dralnage in flat-lyying rocks and trcllia drainage in the vollcy and ridge provincc.......

II-3b Boundaries of rock formations in Tennessee, having comparahle arid-neutralizing raparities, in the same region as Figure II - 3a. Numbers refer to buffering classi-

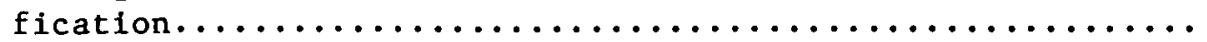


Smoothing of geologic contacts among areas of differing acid-neutralizing capacities in Tennessee, shown in Figure II - $3 \mathrm{~b}$. Numbers refer to buffering classi-

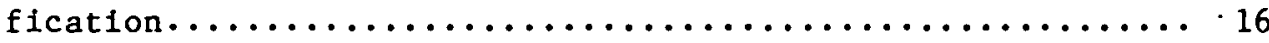

II-4 Predicted susceptibility of surface waters to acidification as determined by bedrock type. Data are organized on a county-by-county basis. The first character of the 2-digit code represents the decade-percent of Type-I rock ( $0=0-9 \%, 1=10-19 \%, 2=20-29 \%$, etc.) and the second character represents the decade-percent of rock type II. The states included are (a) Maine, New Hampshire, Vermont, Massachusetts, Rhode Island, Connecticut, and New York; (b) Pennsylvania, New Jersey, Delaware, Maryland, West Virginia, Virginia, and North Carolina; (c) Minnesota (excluding Western-most counties), Wisconsin, Michigan, and Iowa; (d) Missour1, Illinois, Indiana, Ohio, and Kentucky; (e) Arkansas, Mississippi, Alabama, and Tennessee; and (f) South Carolina, Georgia and Florida...................................

II-5 High altitude lakes (elevation $>600 \mathrm{~m}$ ) in the Adirondack Mountains of New York which have lost their fish populations (A) are shown superimposed on a map of rock-type I. Lakes which still have fish are also indicated (P) .... 23

III-1 Location map of Virginia showing the Shenandoah National Park, the original survey area (large, lightly stippled area), and the smaller study area (darkely shaded). The small study area is the same area as shown in Figure

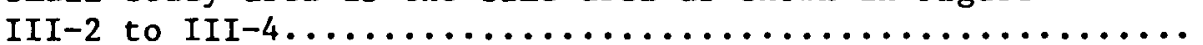

III-2 (a,b) Bedrock geology in the study area in and adjacent to the Shenandoah Natlunal Park...................... 38

III-3 $(a, b) \quad p H$ of streams in the survey area. Shaded areas represent watershed areas upstream from sampling locations......... 39 
$\operatorname{III}-4(a, b)$ Alkalinity of streams in the survey area. Shaded areas represent watershed areas upstream from sampling

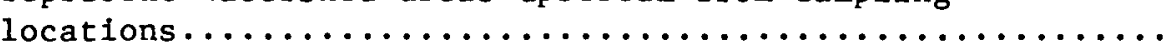
storm of July 16, 1979. Rainfall occurred between 1300

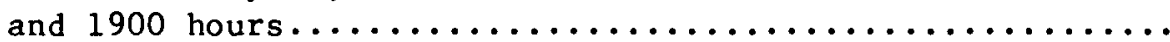

III-6 Geologically based sensitive areas map of New Hampshire. Highest sensitivity (Type-I) is indicated by 1 on the map with 2,3 , and 4 indicating progressively less sensticlve areas. Dashed lines are county boundaries............ 42

III-7 Geologically based sensitive areas map of North Carolina. Highest sensitivity (Type-1) is indicated by 1 on the map with 2,3 , and 4 indicating progressively less sensitive areas. Dashed lines are county boundaries...... 43

III-8 Average hydrogen ion concentrations expressed at $\mathrm{pH}$, of New Hampshire sites included in ACID $(09 / 28 / 79) \ldots \ldots \ldots . \ldots 44$

III-9 Average hydrogen ion concentrations expressed as $\mathrm{pH}$, of the North Carolina sites included in ACID.............. 45

III-10 New Hampshire counties shaded according to the minimum time-averaged alkalinfty observed in each county........ 46

III-11 North Carolina counties shaded according to the minimum time-averaged alkalinity observed in each county.........

III-12 New Hampshire counties shaded according to the average of all alkalinity observations in each county............ 48 


\section{LIST OF FIGURES (cont)}

Figure

$\underline{\text { Page }}$

III-13 North Carolina counties shaded according to the average of all alkalinity observations in each county.............

III-14 Average alkalinity of counties in New Hampshire for the

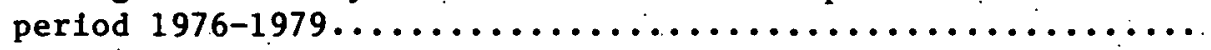

III-15 Average alkalinity of counties in North Carolina for the

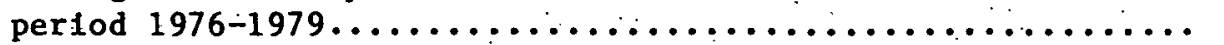

IV-1 North Carolina fisheries data (June, July or August

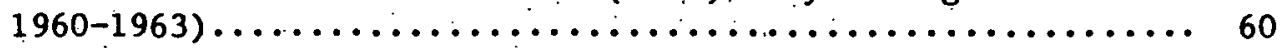

IV-2

North Carolina field trip $(6 / 29 / 79--7 / 4 / 79) \ldots \ldots \ldots \ldots \ldots \ldots 60$

IV-3 North Carolina fisheries data (June, July or August

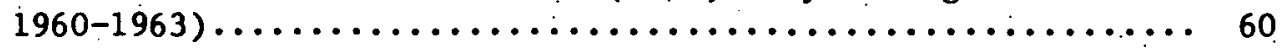

IV-4 North Carolina field trip $(6 / 29 / 79--7 / 4 / 79) \ldots \ldots \ldots \ldots \ldots$

IV-5 Alkalinity vs. alkalinity for North Carolina streams...... 61

IV-6 $\quad$ pH vs. pH for North Carolina streams............... 61

IV-7 New Hampshire fisheries data (summers of 1937, 1938,

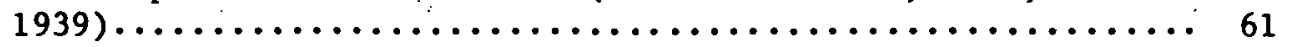

IV-8 New Hampshire field trip $(7-26-79--8-2-79) \ldots \ldots \ldots \ldots \ldots$ 
IV-10 Calcium vs. pH for headwater streams in North Carolina

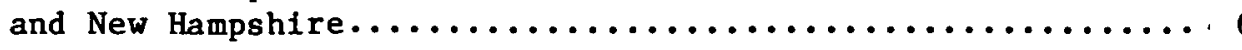

V1-1 Aciditication of Adirondack lakes in relation to $\mathrm{pH}$ measured in 1975 (2.15 lakrs). Mran aridifiration $=99.6$ leqle, $\mathrm{SU} \equiv 30.6$, where acidification $\mu \mathrm{eq} / \ell \equiv 1.42$ (Ca $\mu$ eq $/ \ell$ )

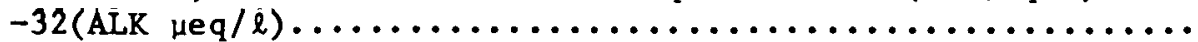

VI-2 Acidification of Adirondack lakes in relation to $\mathrm{SO}_{4}$ measured in 1975 (215 lakes). Regression:

(a) acidification $=0.676\left(\mathrm{SO}_{4} \mu \mathrm{eq} / \mathrm{\ell}\right)$ +10 (data) $(r=0.62, p<.01)$;

(b) acidification $=0.89$ (exs. $\mathrm{SO}_{4} \mu \mathrm{\mu q} / \ell$ ) -12 . Henriksen $197951 \ldots \ldots \ldots \ldots \ldots \ldots \ldots \ldots \ldots \ldots \ldots \ldots \ldots$

VI-3 Nomograph for predicting lake $\mathrm{pH}$ and fish population otatus from lake $C a$ levelo and either regional acidifi cation or precipitation $\mathrm{pH}$. Regression lines for the boundary between $\mathrm{HCO}_{3}$ - and transition lakes, and for the acid lakes boundary with transition lakes, are given in the text as equations (4) and (5) respectively.............

VI-4 Changes in $\mathrm{H}^{+}$concentration in 36 Adirondack lakes from the 1930 's to 1975 , in relation to $\mathrm{Ca}$ levels measured in 1975. The arrow designates the critical Ca level for loss of $\mathrm{HCO}_{3}$ buffering, as predicted from Henriksen's 53 modcl for a region cxposed to prccipitation with a

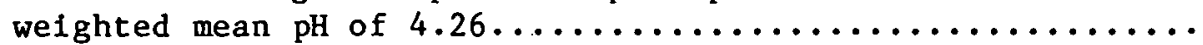




\section{INTRODUCTION}

In recent decades, man's activities have led to significant changes in atmospheric and precipitation chemistry. Among these activities, metal smelting and combustion of fossil fuels have resulted in atmospheric emissions of sulfur and nitrogen oxides. The effect of these emissions has been a dramatic increase in the acidity of rainfall, particularly in areas downwind of major industrial areas. Although the phenomenon of acidic precipitation has been developing on a hemispheric scale, only recently have workers tried to identify those areas in the United States recelving acidic precipitation 16,71 and associated heavy metals.67 While a reasonably good understanding of the sources and distribution of acid precipitation has been developed, 16, 18, $19,27,71,72,77$ our understanding of the effects of acidic precipitation on terrestrial and aquatic systems is still fragmentary. Reductions of $\mathrm{pH}$ and alkalinity of lakes affected by acidic precipitation have been well documented, particularly in the northeastern United States, southeastern Canada, and Scandanavia. In these same areas, declines in fish populations and adverse effects on other aquatic fauna have been widely observed.1,23,37,38, $41,42,49,57,68,86,91,92,103,104$

Studies of the hydroblological problems caused by acidic precipitation have been primarily qualitative. Biological aspects of the synoptic lake surveys in Sweden, 1 Norway, ${ }^{49}$ Canada, 18 and the United States 90 have concentrated on changes in presence or absence of $\mathrm{fish}$ and in the kinds and numbers of species. Very little quantitative information is avallable concerning the effects of acidification on blomass. This is especially true for the bacterla, and other microorganisms. There is strong evidence indicating that processes such as phytoplankton production and microbial decomposition are inhibited, but quantitative data are scarce. Changes in the availability of Inorganic nutrients and in nutrient recycling are hypothesized but have not been demonstrated; effects on food chains or webs are not well known, and no quantitative data are available concerning the effects on energy processing in natural aquatic ecosystems.

The overall objective of the sensitive areas project has been to evaluate the eastern United States and determine and map which areas are vulnerable to adverse impacts from acid precipitation. In addition, a review of the biolog1cal consequences of freshwater acidification is presented and a regional assessment of effects on fish, which provides a basis for predicting such 1mpacts, is described.

\section{A. Geologic Controls}

Impact to aquatic ecosystems is largely based on the chemical characteristics of the bedrock. Limestone terrains yield "Infinite" acid-neutralizing (buffering) capacity to acidic precipitation whereas granites (and related lgneous rocks), their metamorphic equivalent, and noncalcareous sandstones yield minimal buffering. Several hundred common minerals comprise the huge varlety of rocks which comprise the crust of the earth, the surficial overburden, and soils. Of interest in terms of susceptibility of a landscape to 
acidification from precipitation is the total capacity of the minerals, no matter what their configuration, to assimilate protons $\left(\mathrm{H}^{+}\right.$aq $)$. Specific considerations are solubility of the phases and the kinetics of solution.

Certain minerals are soluble and rapidly dissolved but yield no buffering capacity, e.g.:

$$
\mathrm{NaCl}_{\mathrm{xl}}=\mathrm{Na}^{+}{ }_{\mathrm{aq}}+\mathrm{Cl}^{-} \mathrm{aq} \quad \mathrm{K}_{\mathrm{sp}}=10^{+1} \cdot 58=\left[\mathrm{Na}^{+}\right]\left[\mathrm{Cl}^{-}\right]
$$

Others are relatively insoluble and yield no buffering capacity, e.g.

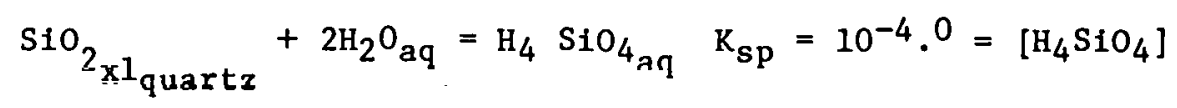

Common rock forming minerals, when placed in water, yiel, $\mathrm{pH}^{\mathrm{s}} \mathrm{s}$ in excess of 7 (commonly in excess of 8 ) but the kinetics are sufticiently slow so that the total potential $\mathrm{H}^{+}$consuming capacity of these minerals is not realized, e.g.:

$$
\begin{aligned}
& 2 \mathrm{NaAlSi}_{3} \mathrm{O}_{8} \mathrm{x}_{\mathrm{albite}}+2 \mathrm{II}_{\mathrm{aq}}^{+}+9 \mathrm{H}_{2} \mathrm{O}_{\mathrm{aq}}= \\
& =2 \mathrm{Na}_{\mathrm{aq}}^{+}+\mathrm{Al}_{2} \mathrm{Si}_{2} \mathrm{O}_{5}(\mathrm{OH})_{4 \times 1_{\text {kaolinite }}}+4 \mathrm{H}_{4} \mathrm{SiO}_{4} \mathrm{aq}^{\circ} \\
& \mathrm{K}_{\mathrm{sp}}: 10:\left[\left[\mathrm{Na}^{+}\right]^{2} /\left[\mathrm{H}^{+}\right]^{2}\right]\left[\mathrm{H}_{4} \mathrm{SiO}_{4}\right]
\end{aligned}
$$

Assuming an initial $\mathrm{pH}$ of 4.0 and buffering from the $\mathrm{CO}_{2}-\mathrm{H}_{2} \mathrm{O}$ system $\left(\mathrm{HCO}_{3}^{-}=10^{-5.7}\right)$, the expected $\mathrm{pH}$ after complete reaction would be approximately 12. This is never achleved.

Additional $\mathrm{H}^{+}$sinks available in soils include $\mathrm{Al}$ and $\mathrm{Fe}$ hydroxides and silicates, e.g.:

$$
\begin{aligned}
& \mathrm{Al}_{2} \mathrm{Si}_{2} \mathrm{O}_{5}(\mathrm{OH})_{4 \times l_{\mathrm{kaO}} \text { inite }}+6 \mathrm{H}^{+} \mathrm{aq}=2 \mathrm{Al}_{\mathrm{aq}}+3+2 \mathrm{H}_{4} \mathrm{SiO}_{4} \mathrm{aq}+\mathrm{H}_{2} \mathrm{O}_{\mathrm{aq}}
\end{aligned}
$$

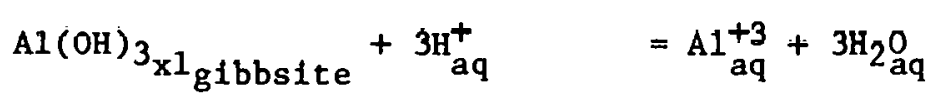

$$
\begin{aligned}
& \mathrm{FeO}(\mathrm{OH})_{\mathrm{XI}} \text { geothite }+3 \mathrm{Haq}^{+}+\mathrm{e}^{-}=\mathrm{Fe}_{\mathrm{aq}}^{+3}+2 \mathrm{H}_{2} \mathrm{O} \text { aq }
\end{aligned}
$$

These minerals are either developed in sub-solls (B-horizon) in young soils (and thus not necessarily available to overland flow) or dominate in mature/old solls where they may provide extensive acid neutralizing capacity.

The most important mineral for neutralizing acidic waters is calcite (or nearly any other carbonate mineral). The solution at low and at intermediate $\mathrm{pH}$ of this mineral is given by: 


$$
\begin{aligned}
& \mathrm{CaCO}_{3}+2 \mathrm{H}_{\mathrm{aq}}^{+}=\mathrm{Ca}+\mathrm{aq} \\
& 2 \mathrm{CaCO}_{3}+2 \mathrm{H}_{2}^{+} \mathrm{CO}_{3 \mathrm{aq}}=2 \mathrm{Ca}_{\mathrm{aq}}^{++}+2 \mathrm{HCO}_{3}^{-} \text {at low } \mathrm{pH} \text { and }
\end{aligned}
$$

Further addition of acid to the resulting (7b) solution $\left(2 \mathrm{Ca}^{++}+2 \mathrm{HCO}_{3}^{-}\right)$will result in the protenation of the $\mathrm{HCO}_{3}{ }^{-}$:

$$
\mathrm{HCO}_{3}^{-}+\mathrm{H}_{\text {aq }}^{+} \quad \mathrm{H}_{2} \mathrm{CO}_{3} \text { aq }
$$

These reactions ( 7 and 8 ) are rapid and for each mole of $\mathrm{CaCO}_{3}$ consumed, 2 moles of $\mathrm{H}^{+}$are consumed before the $\mathrm{pH}$ is reduced significantly below 5 . Reactions, 4, 5, and 6 or similar reactions consume large amounts of $\mathrm{H}^{+}$ions at $\mathrm{pH}$ 's below 5 and may be the primary acid-consuming mechanism for very acidic solutions. They do not contribute $\mathrm{HCO}_{3}{ }^{-}$for buffering except by virtue of the dissoctation of $\mathrm{H}_{2} \mathrm{CO}_{3}$ as the $\mathrm{pH}$ is raised by the reactions:

$$
\mathrm{H}_{2} \mathrm{CO}_{3 \mathrm{aq}} \rightarrow \mathrm{H}_{\mathrm{aq}}^{+}+\mathrm{HCO}_{3 \mathrm{aq}^{-}}^{-}
$$

The amount of $\mathrm{HCO}_{3}{ }^{-}$produced will be a function of the total $\mathrm{CO}_{2}$ in the system. It should be noted that the gain or loss of molecular $\mathrm{CO}_{2}$ to the water, by itself with no addition of cations to balance $\mathrm{HCO}_{3}^{-}$production, will not change alkalinity although $\mathrm{pH}$ does change.

Thus we have a spectrum of response of minerals (and rocks) to the changing acidity of atmospheric precipitation. Accordingly, rocks may be classified by the buffering capacity or acid-neutralizing capacity which they render to surface waters.

Additional controls on acidification of aquatic ecosystems include: hydrologic characteristics of the terrain. (1.e. overland flow versus groundwater flow, soll pórosity/permeability, residence time of water in the soil, distribution of precipitation through time, type of precipitation, thickness of sol1), types of soils (residual, glacial [t1l1, ice-contact stratifled, etc.], aeolian, larjustrine, alluvial, etc.), minerology and age of soil.

Any prediction about the vulnerability of a terrain to acidification from precipitation based solely on bedrock geology must be tempered with consideration of these other factors. For example, Florida is underlain by highly calcareous and phosphatic rocks suggesting that acidification of lakes and streams is highly unlikely. However, many of the solls (particularly in northern Florida) are very mature, highly leached of $\mathrm{CaCO}_{3}$ and as a result, acidification of some lakes with minimal deep groundwater influx has occurred (P. Brezonik, pers. comm. 1979). Conversely, there are areas in Maine underlain by granite and receiving precipltation with an average $\mathrm{pH}$ of about $4.3^{78}$ where lakes have not been acidified because of lime-bearing till and marine clay in the drainage basins of the lakes. 
B. Mapping of Areas Sensitive to Acid Precipitation.

Other investigations $33,64,71$ have defined areas of the United. States and Canada as susceptible to impacts from acidic precipitation, from interpretations of large-scale geologic maps. These areas were largely concentrated in Precambrian terrains (the Canadian shield, the Adirondack Massif), the Precambrian core of the Appalachian Mountains, and in younger igneous rocks of the Northwest and Rocky Mountains.

In the United States surface waters acidified from atmospheric deposition have now been identified from New England and New York to Florida, and in the Boundary Waters Canoe Area, Minnesota. Acidic precipitation exists (with pH (5.6) in all states contiguous to the Mississippi River and east to the Atlantic 0cean 78 as well as in California ${ }^{72}$ and in Washington. 6 Because of this widespread aspect of acidic precipitation, it is important to understand the natural characteristics of the landscape which render an area's aquatic ecosystems susceptible to impact. Three major factors can be identified as important. They are: meteorology, pedology, and geology. This report stresses the geological control of sensitivity.

\section{Water Quality Data Collection.}

The utflity of the geologically-based maps of sensitive areas is limited by the accuracy with which they identify areas in which surface waters are actually sensitive. We define sensitive waters as those with alkalinity values less than 500 ueq (micro equivalents) of alkalinity per liter. The accuracy of the maps was checked against actual measurements of lake and stream water chemistry.

Data from existing records in many states of the eastern U.S., from the STORET system, and from field measurements conducted in New Hampshire and North Carolina in 1979 are combined in the Acidification Chemistry Information Database (ACIU) at Brookhaven Narfonal Laboratory. Data is registered by state, county, scation code, station name, dala suulce cude, latitude, longitude, and sample date. Data sets include $\mathrm{pH}$, alkalinity $(\mu$ eq/1), Ca $(\mu \mathrm{eq} / 1)$, conductivity (microSiemens), color (mgPt) and fish status. Information on methods used for chemical determinations is also stored in ACID. 
An analysis of the vulnerability of aquatic ecosystems to acidification from precipitation must start with the bedrock geology. The scale of variability of rock types is such that one must literally look at the geology on a drainage basin basis to make predictions about individual lakes and streams. Igneous rocks normally have maximum dimensions less than $10 \mathrm{~km}$. Folded/ faulted metasedimentary/sedimentary rocks may have essentially 1-dimensional distribution. Flat lying sedimentary rocks may be widely distributed but topographic relief commonly intersects many rock types over short distances.

Small amounts of limestone in a drainage basin exert an overwhelming influence on water quality in terrains which otherwise would be very vulnerable to acidification. Consequently, in the regional analysis of vulnerability, areas with intimate mixtures of rocks of varying acid neutralizing capacity have been classifled according to the more influential rock types. Analysis of geologic terrain has been undertaken on the scale of the most recent state geologic maps (Table II-1). Rock formations have been classified according to their potential buffering capacity. This judgment was based on map explanations, various stratigraphic lexicons 61,62 and $S$. Norton's personal knowledge of the geology of areas.

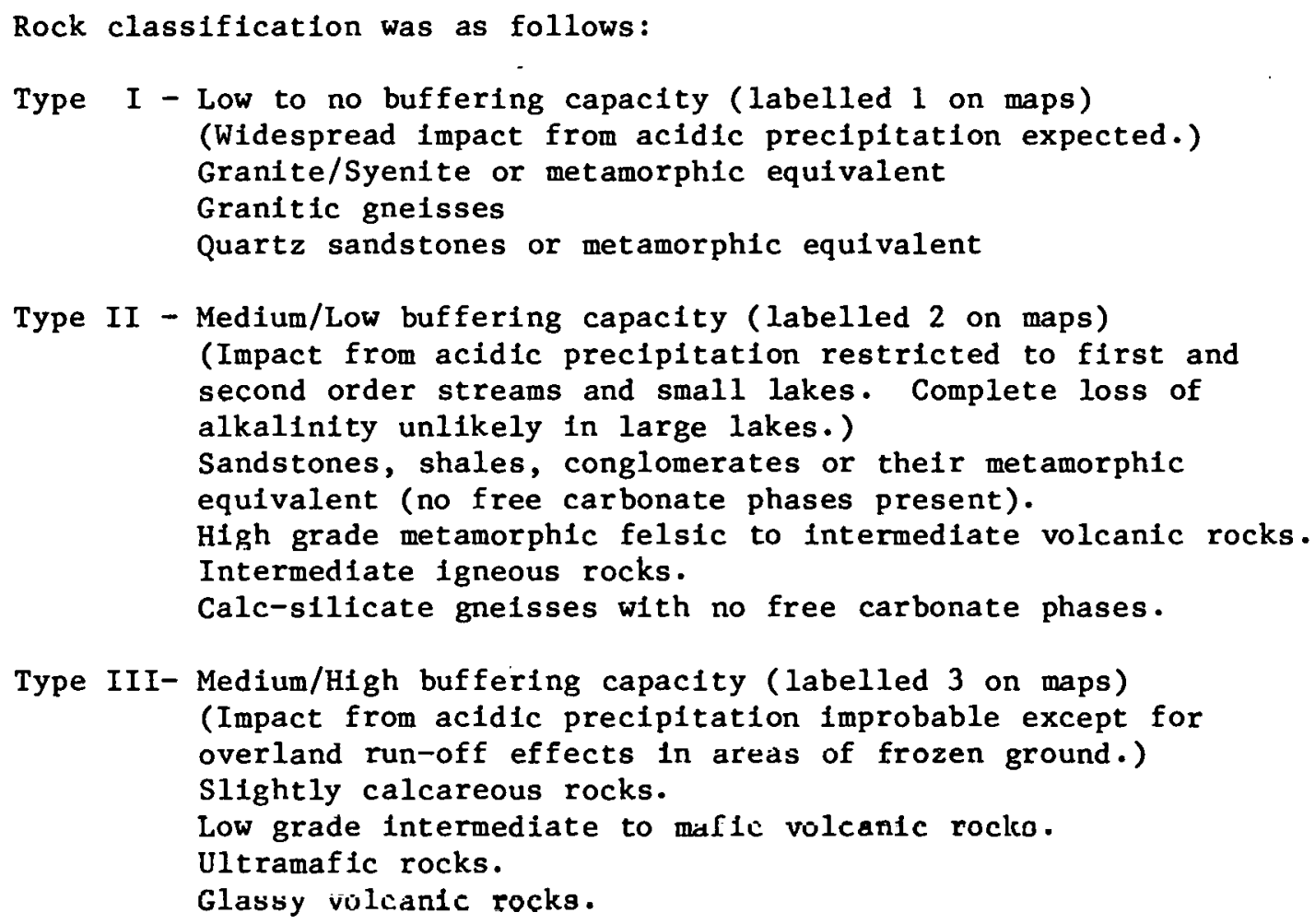




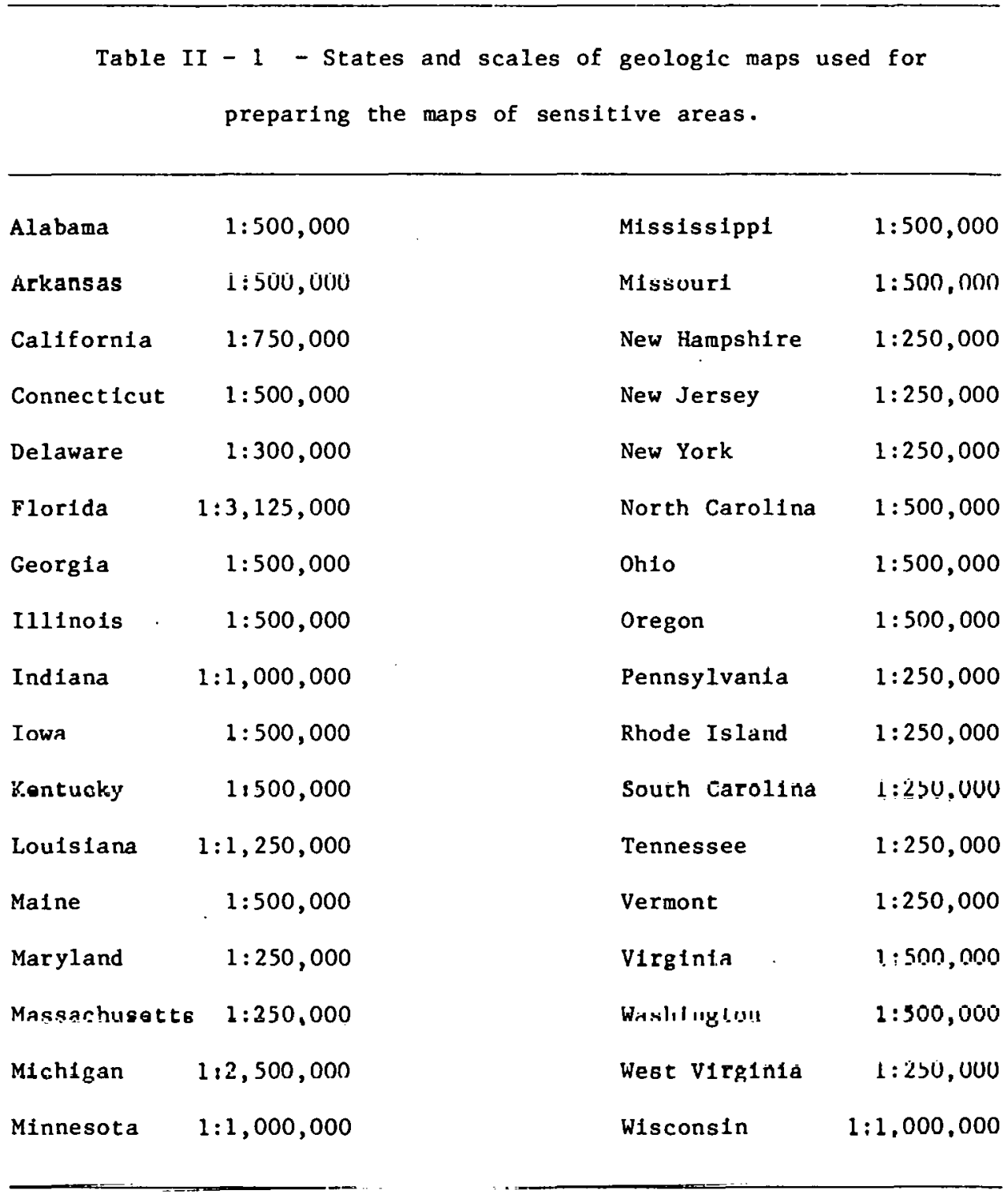


The development of vulnerability maps for 3 types of terrains are illustrated in scveral steps. Figure II-la represents, unmodified, a tracing of all boundarles of geologic formations shown on part of the North Carolina state geologic map. This area is underlain by precambrian and possibly lower palezoic rocks which are highly folded, faulted and metamorphosed in the core of the Appalachian Mountains. Figure II-lb differs from II-la in that boundaries between contiguous formations with comparable acid-neutralizing capacities are not shown. Figure II-lc is modified from II-lb by the smoothing of contacts, favoring rocks with higher buffering capacity, and the deletion of small areas or linear outcroppings of low buffer capacity rocks.

Figure II-2a represents, unmodified, a tracing of all boundaries of geologic formations shown on part of the New York state geologic map. This Precambrian terrain is characterized by high grade metamorphic rocks intruded by many igneous rocks, largely granitic. Figures II-2b and II-2c are developed by the same techniques as Figures II-1b and II-lc.

Figures II-3a, b and c represent similar development for a portion of the state of Tennessee in an area of dendritic drafnage in flat-lying sedimentary rocks (western half) and valley and ridge topography in the highly folded paleozoic section (eastern half).

The state geologic maps already represent a smoothing and generalization of geologic boundarles. Most state maps utilized in this synthesis have been drawn at a scale of $1: 250,000$ or $1: 500,000$ from maps at a scale of $1: 24,000$ or $1: 62,500$ with the loss of much small detail. At a scale of $1: 250,000$ the largest geologic unit that is commonly deleted is approximately 0.2 miles in dlameter or width.

"Zero"-dimensional rocks of this size (generally intrusions or erosional remnants of flat lying strata) will not normally affect the chemistry of a large number of streams or lakes. However, one-dimensional rock map units (generally the intersection of moderately to steeply dipping strata or dikes or metamorphic equivalents) commonly affect large numbers of primary and secondary streams and lakes which lie in topographic lows occupied by certain strata. Thus, thin limestones in the Valley and Ridge topographic province (Figure II-3a) may not be shown on a scale of 1:500,000 (and thus not on these maps) but may dominate the area's water chemistry and vulnerability to acidic precipitation.

The geologically based sensitivity maps have also been organized on a county basis to make these data compatible with existing data bases for soils, agriculture, forestry, and other land uses. (A new solls map, being prepared by a separate project $\$ 4$ will also be organized on a county basis so analyses of county susceptiblitity to acidification of surface waters may be undertaken.) Each county in the study area states (Table II-1) was analyzed by planimetry for percentage of area underlain by rock types I and II. These data are shown for the Eastern United States in Figure II-4. Although individual drainage systems or lakes cannot be analyzed in this fashion, regions of high vulnerability can be identified. The first digit of the binary number for each county represents the percentage $(0-9 \%=0,10-19 \%=1$ etc.) of rock type $I$ in the county. The second digit represents a similar 
decade value for rock type II. For example the number 23 indicates that $20-29 \%$ and $30-39 \%$ of the county is underlain by rock types I and II, respectively. Rock types III and IV are not represented in these maps.

The predictiveness of the maps can be established by comparing the geology-based maps against surface water chemical data in areas receiving acidic precipitation as discussed in section III of this report or by looking at the biological response of aquatic ecosystem to acidic precipitation. A number of lakes in the Adirondack Mountains have been examined in terms of lake $\mathrm{pH}$ and fish populations, 92 as discussed in Section VI of this report, and a close correlation between the two was found. Figure II-5 depicts those lakes which have lost their fish populations and the rock type underlying the area. A geographic correlation exists between fish absence and the existence of rock types $I$ and II in this region. Topography and orographic precipitation are factors contributing to the distribution of lakes in which fish dre present or absent.

Correlations also exist between acidification of surface waters and bedlock geology (Ecction III) in a number of states and areas which have thin soils, including New England. 22 'Ih1s suggests that bediuck geology excrto a very strong influence on the regional extent of acidification of aquatic ecosystems in response to atmospheric loading of acid. Regionally, soils and vegetative types are of secondary importance. However, locally, soils may overwhelm bedrock influences. 


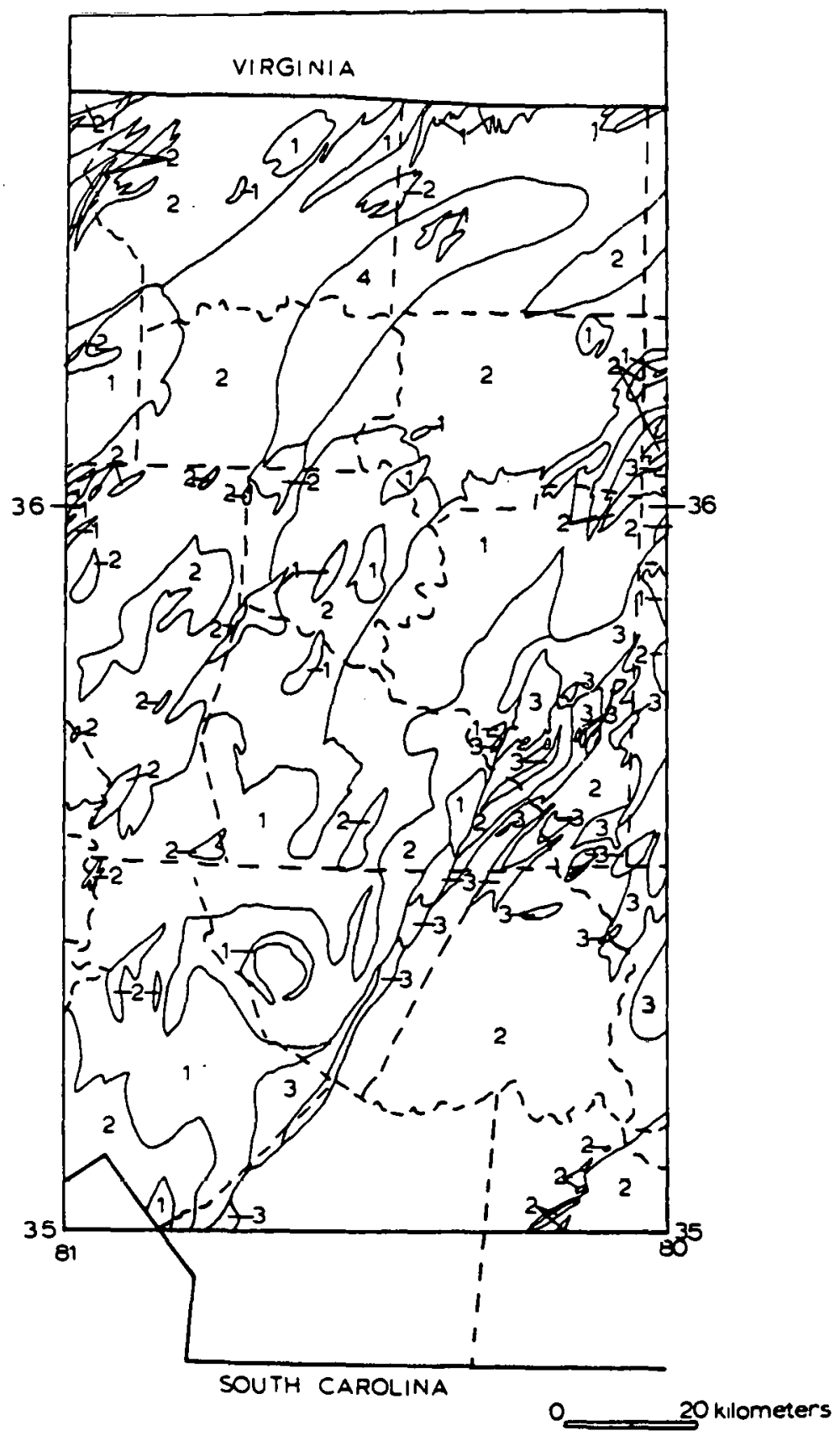

Figure II-la. Unmodified Tracing of All Boundartes of Geologic Formations Shown on a Portion of the North Carolina State Geological

Map. Numbers Refer to Buffering Classification 


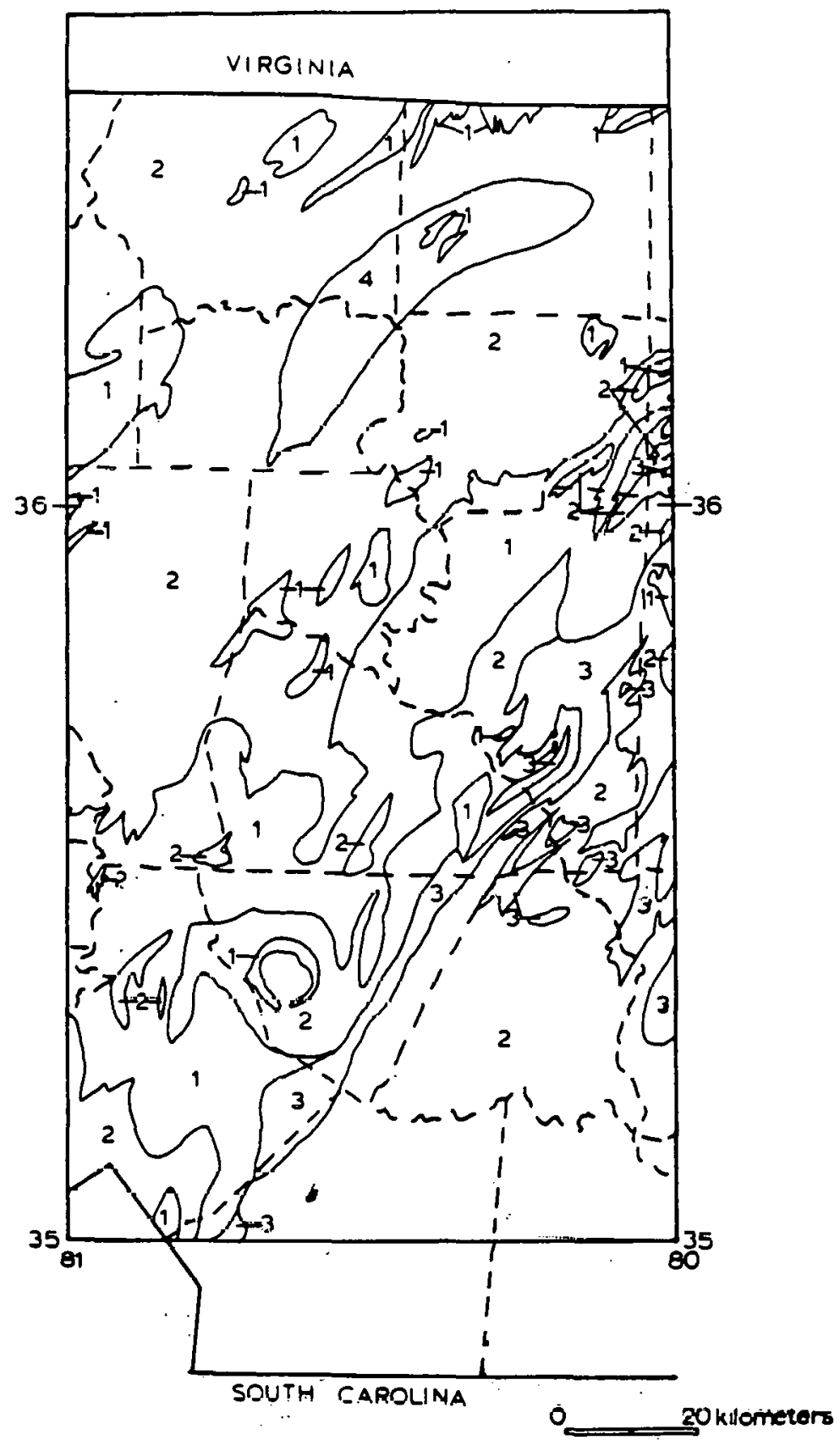

Figure II-1b. Boundaries of Rock Formations in North Carolina Having Comparable Acid-Neutralizing Capacities. Numbers Refer to Buffertng Classification 


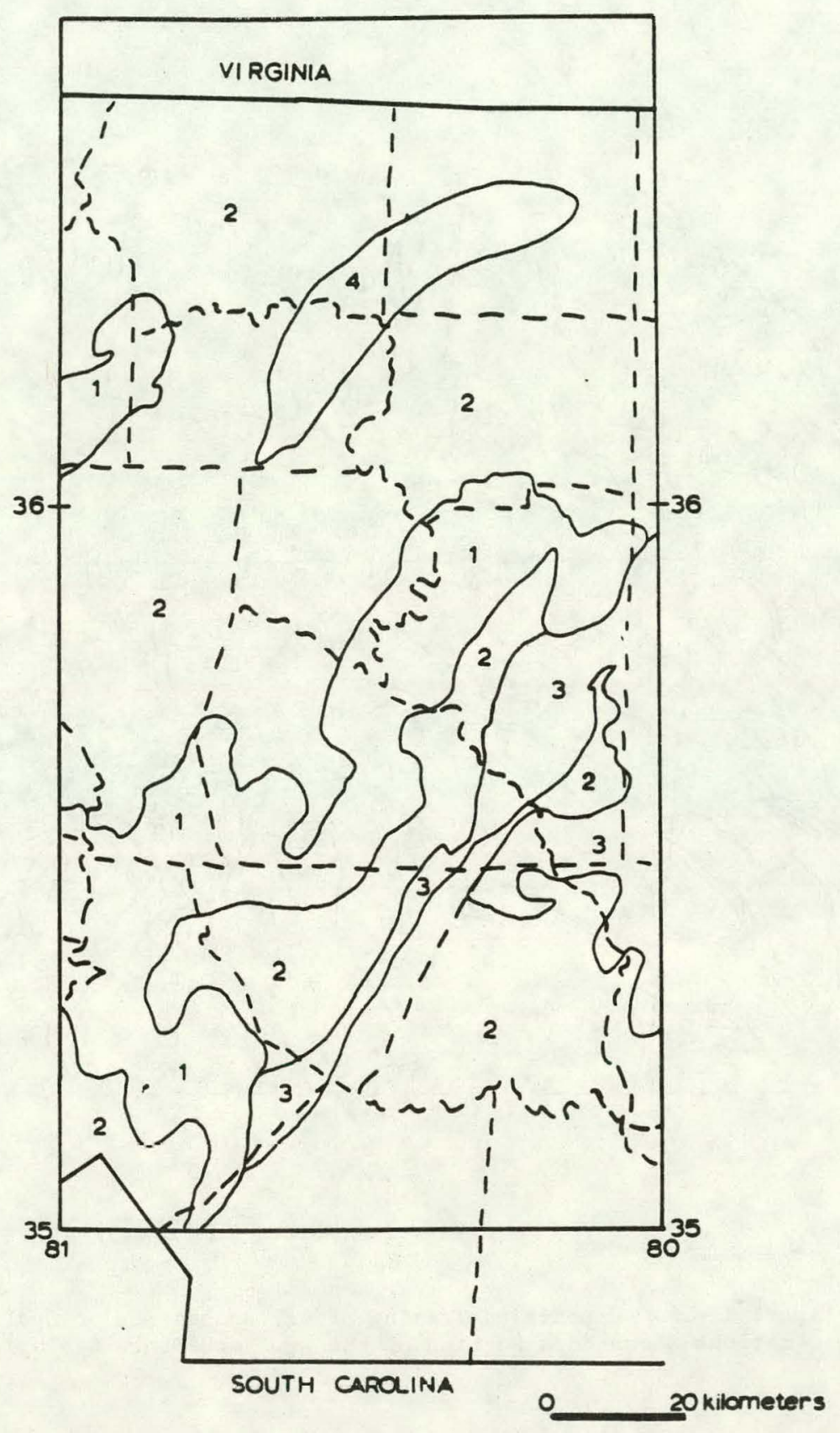

Figure II-1c. Smoothing of Geological Contacts Among Areas of Differing Acid-Neutralizing Capacities Shown in Figure II-1b. Numbers Refer to Buffering Classification 


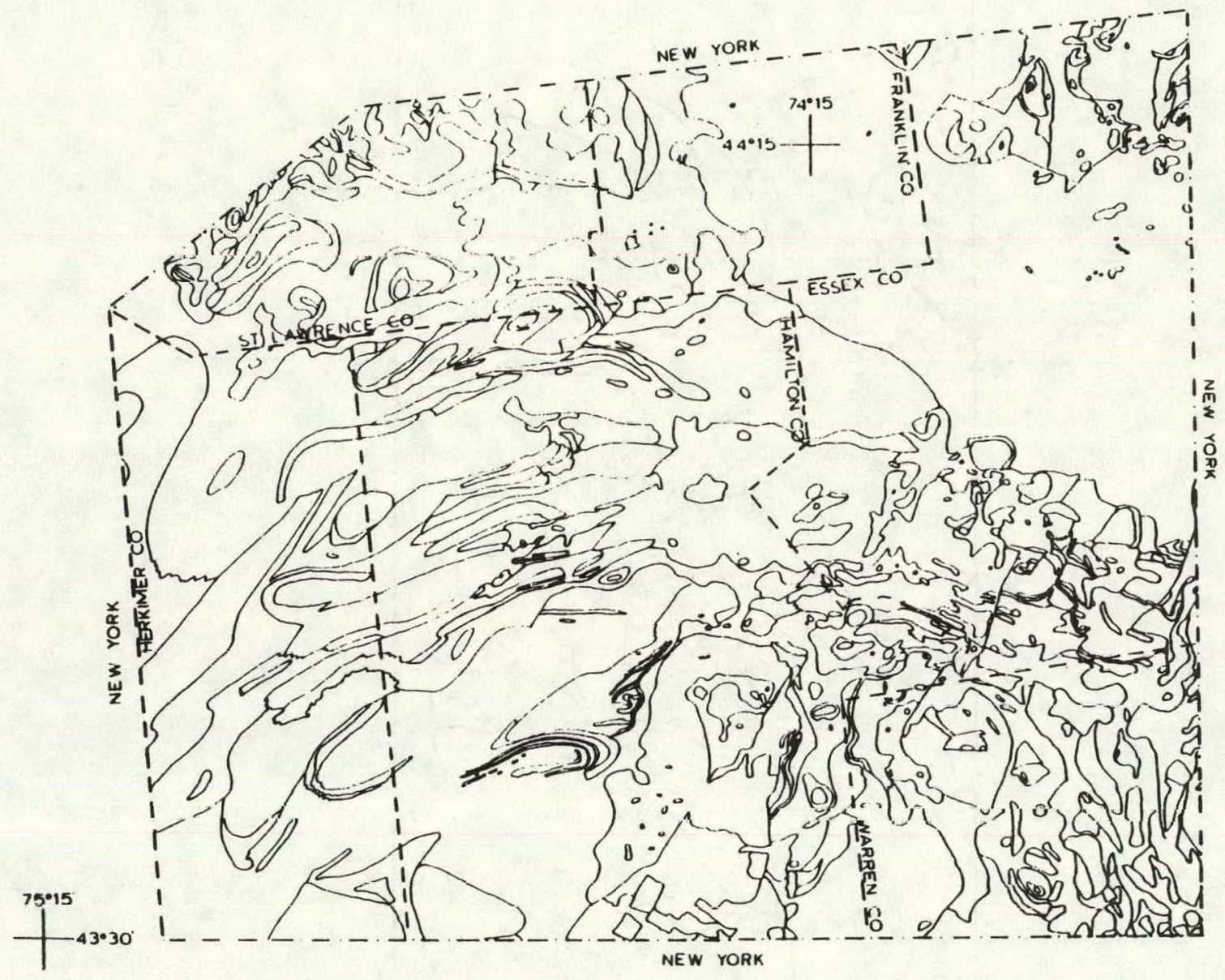

\footnotetext{
o jokilometers

Figure II-2a. Unmodified Tracing of All Buundas les of Geulugic Fui-mations Shown on a Portion of the New York State Geological Map
} 

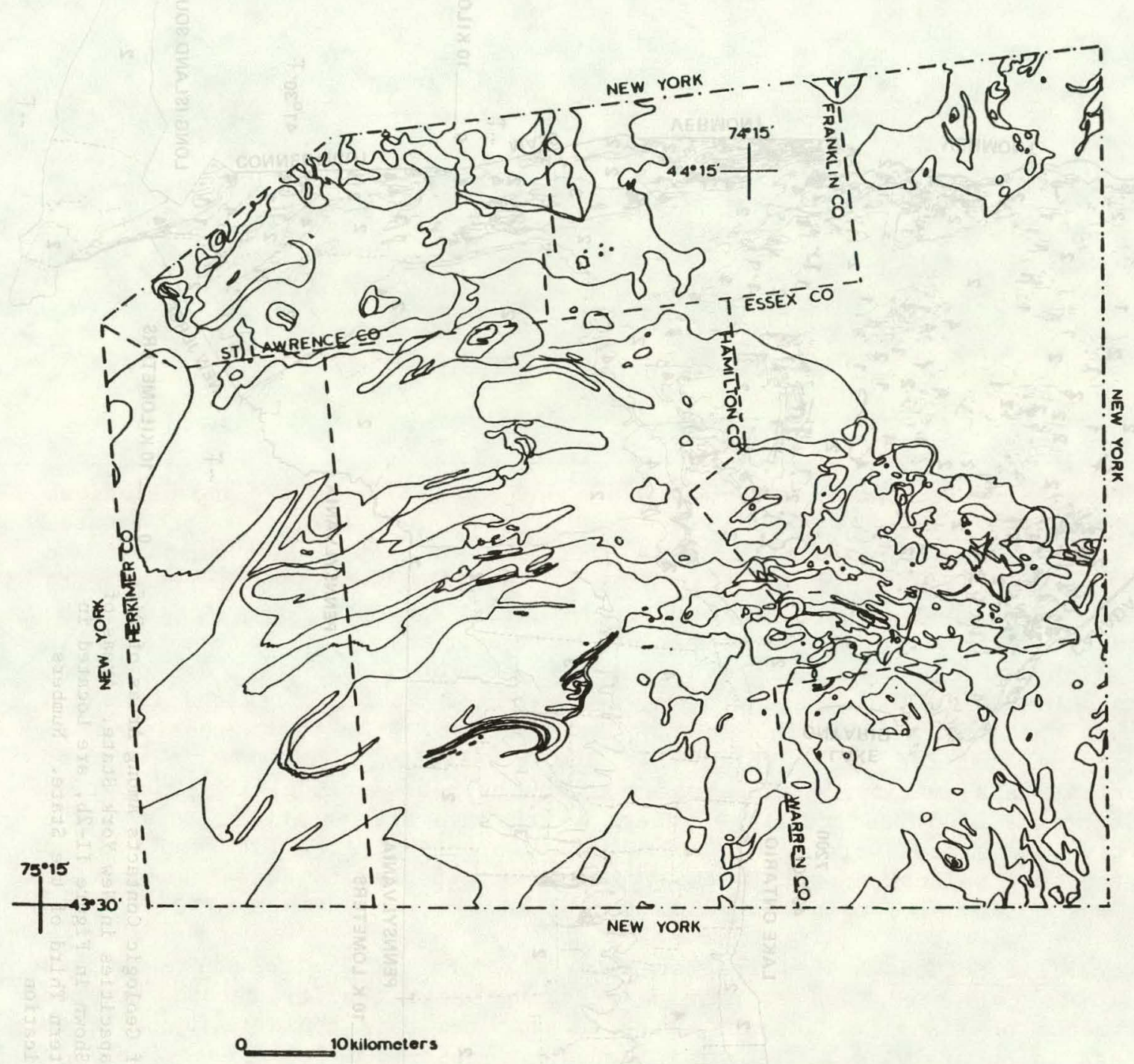

Figure II-2b. Boundaries of Rock Formations in New York Having Comparable Acid-Neutralizing Capacities 


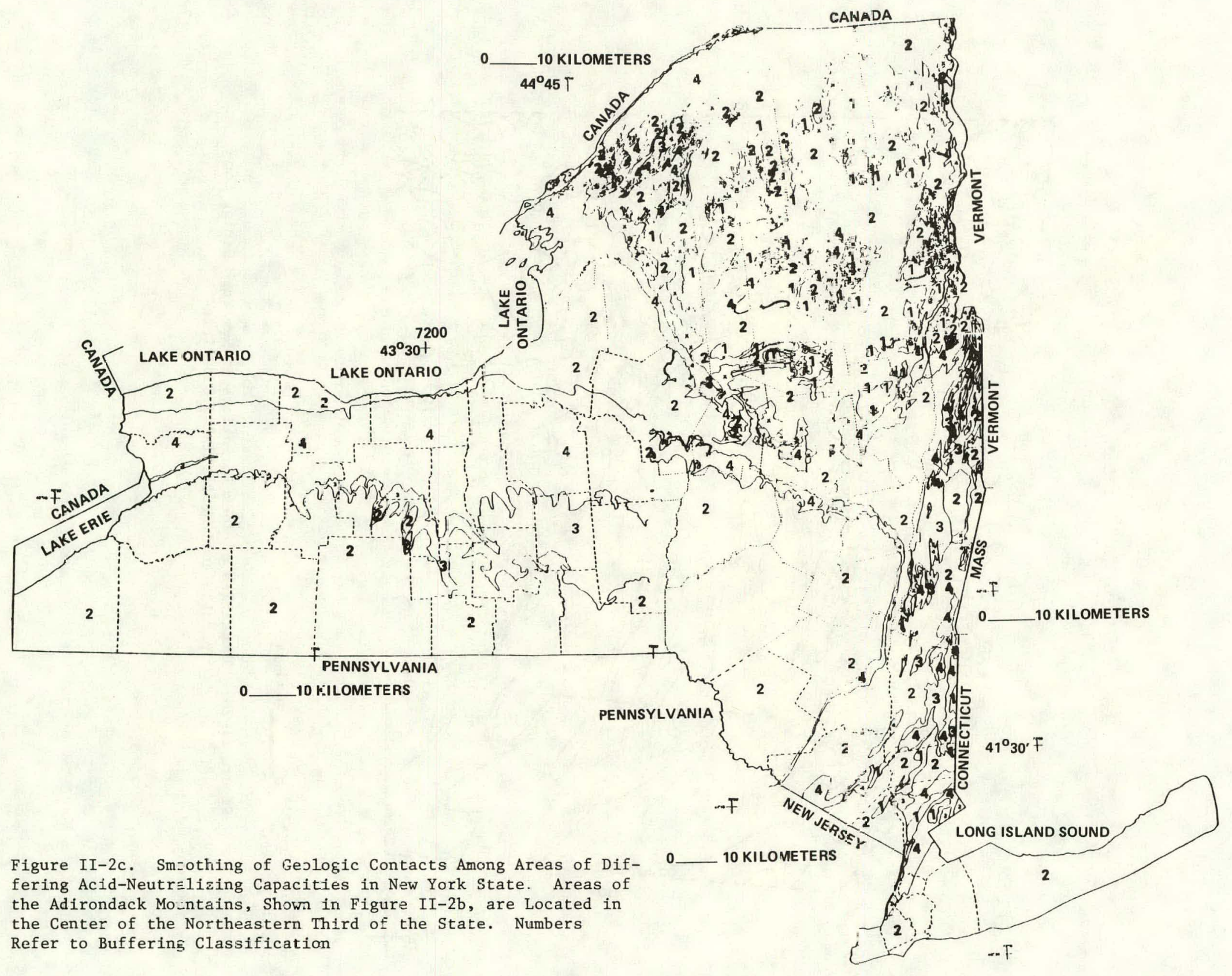




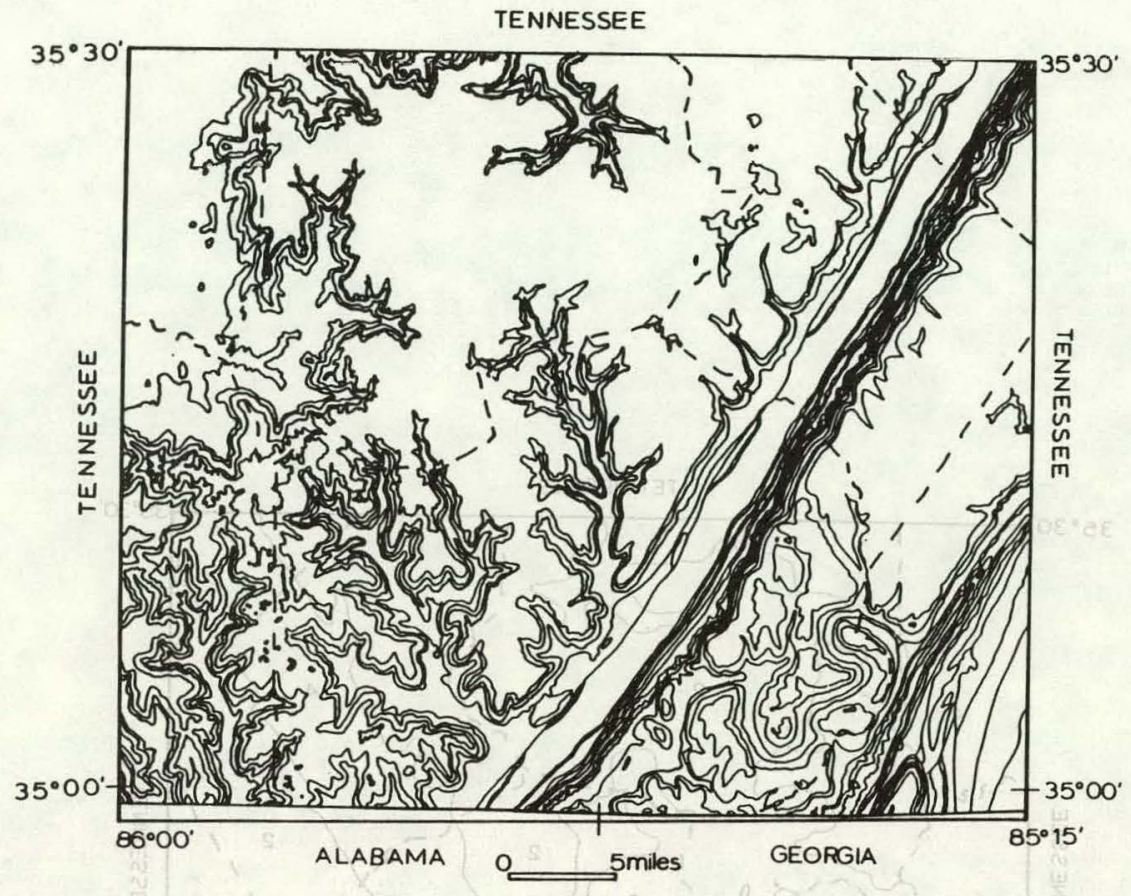

Figure II-3a. Unmodified Tracing of A11 Boundaries of Geologic Formations Shown on a Portion of the Tennessee State Geologic Map in a Region of Dendritic Drainage in Flat-Lying Rocks and Trellis Drainage in the Valley and Ridge Province.

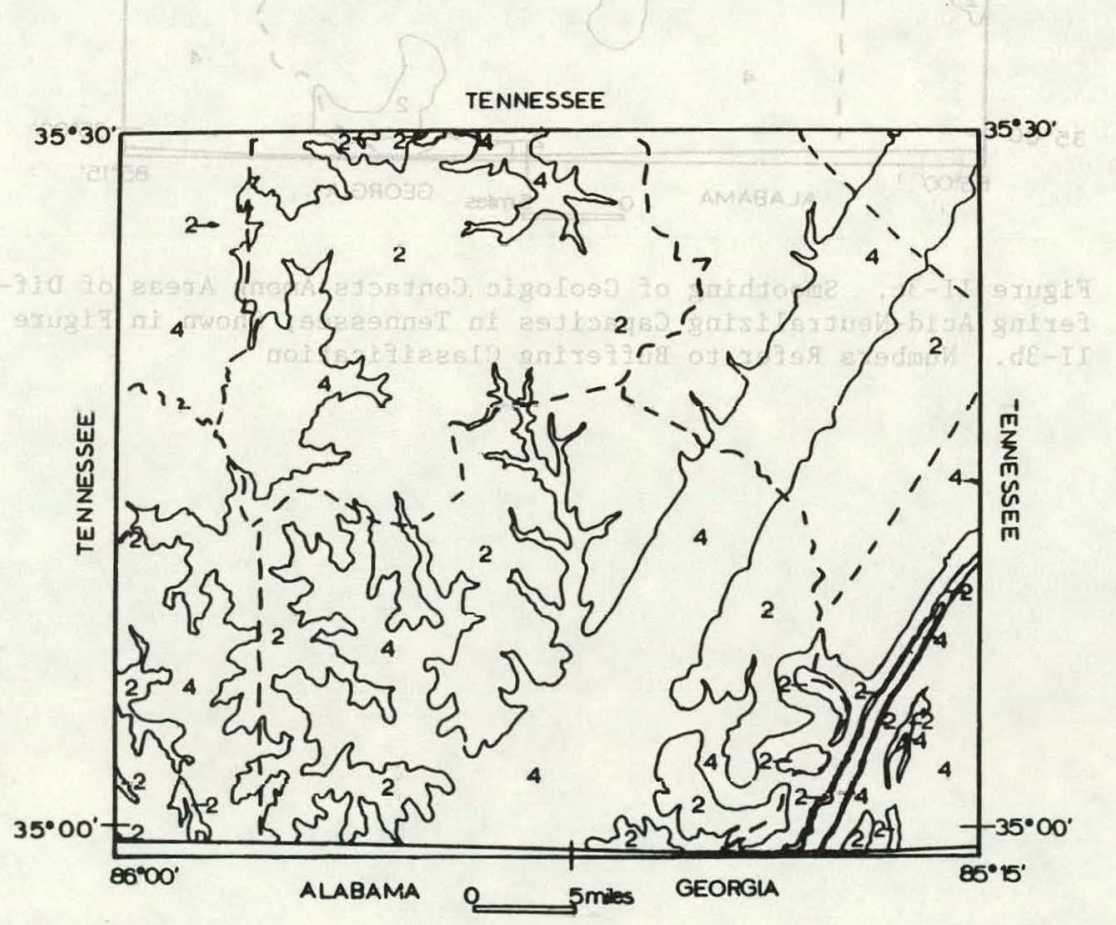

Figure II-3b. Boundaries of Rock Formations in Tennessee, Having Comparable Acid-Neutralizing Capacities, in the Same Region as Figure II-3a, Numbers Refer to Buffering Classification 


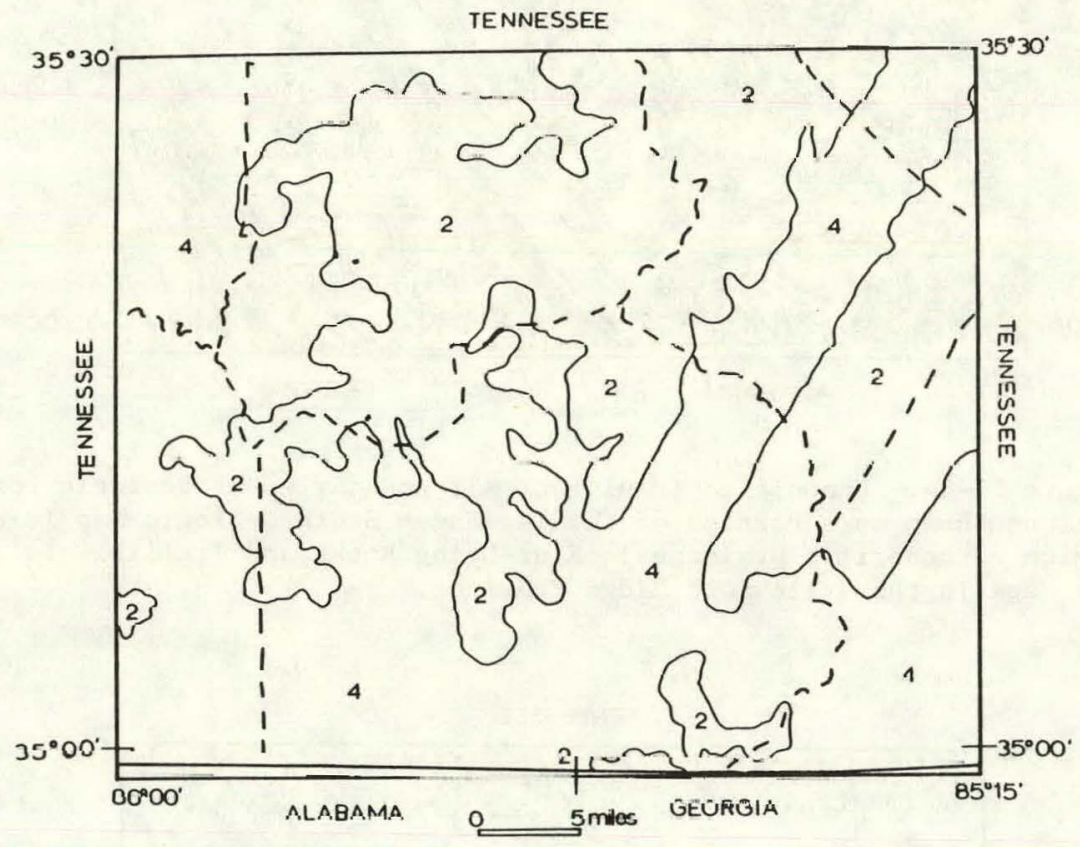

Figure II-3c. Smoothing of Geologic Contacts Among Areas of Differing Acid-Neutralizing Capacites in Tennessee, Shown in Figure II-3b. Numbers Refer to Buffering Classification 
F-gure II-4-(a). Predicted Susceptibility of Surface Waters to Acidification as Determined by Bedrock Type. Data are

arganized on a County-by-Jounty Basis. The First Character of the 2-Digit Code Represents the Decade-Percent of Type-I Eock ( $0=0-9 \%, 1=10-19 \%, 2=20-29 \%$, etc. $)$ and the Second

Character Represents the Jecade-Percent of Rock Type II.

The States Included are Maine, New Hampshire, Vermont,

Massachusetts, Rhode Island, Connecticut and New York

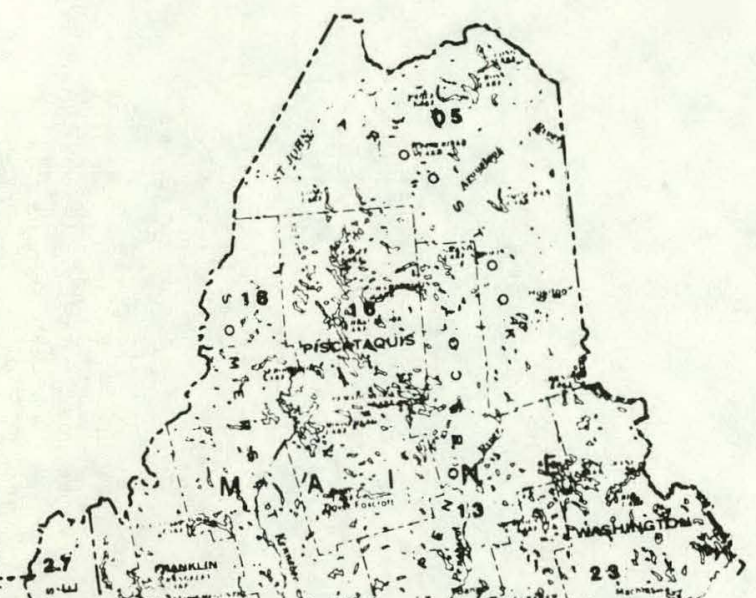

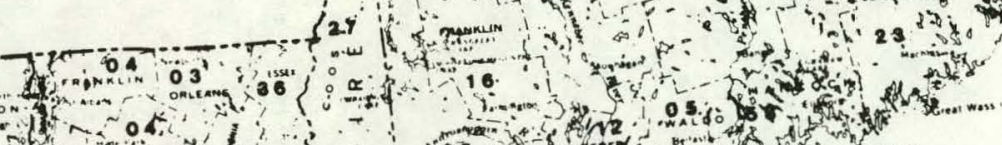

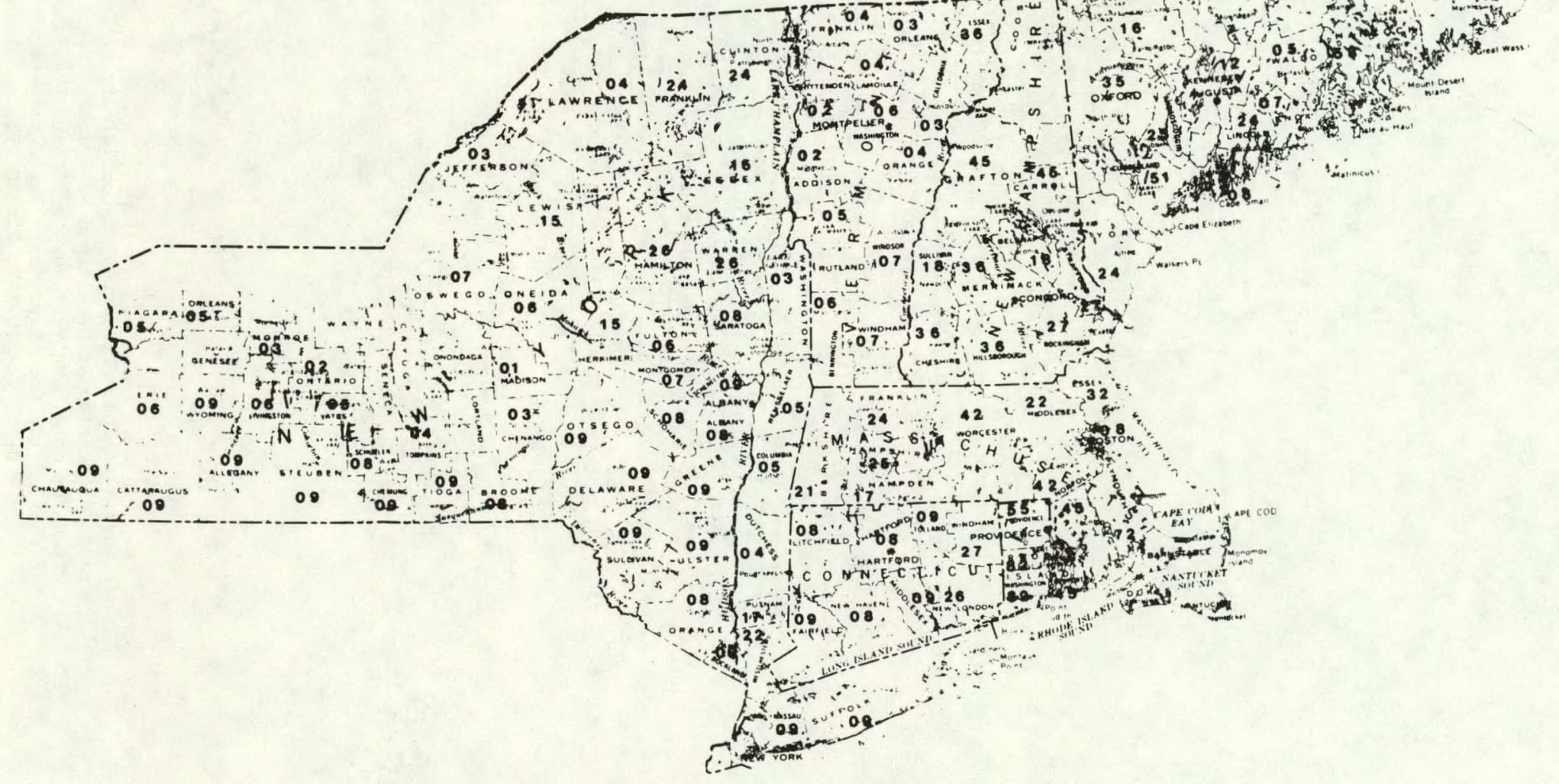




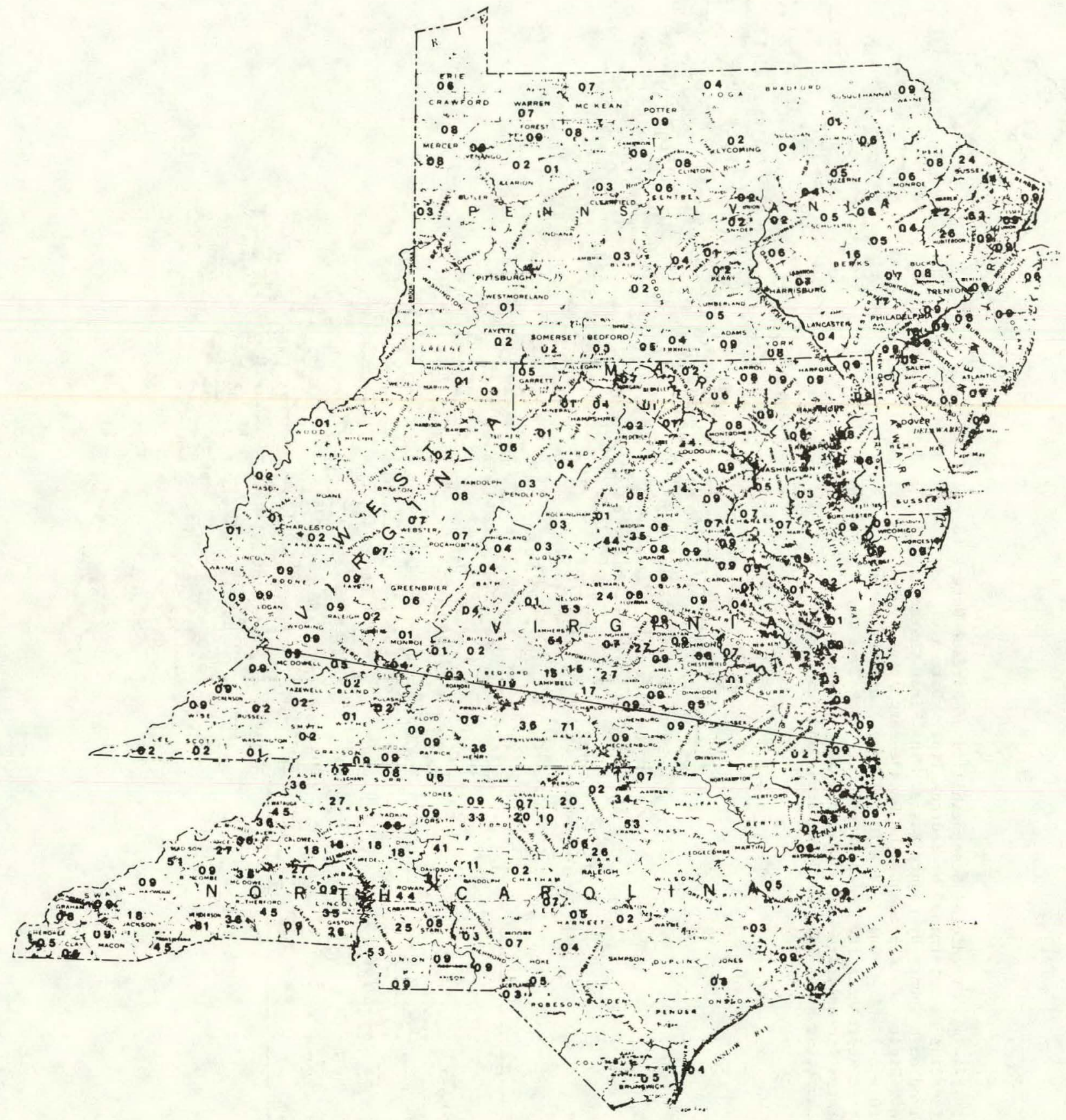

Figure II-4-(b). Predicled Susceptibility of Surface Waters to Acidification as Determined by Bedrock Type. Data are Organized on a County-by-County Basis. The First Character of the 2-Digit Code Represents the Decade-Percent of Type-I Rock ( $0=0-9 \%, 1=10-19 \%, 2=20-29 \%$, etc.) and the Second Character Represents the Decade Percent of Rock Type II. The States Included are Pennsylvania, New Jersey, Delaware, Maryland, West Virginia, Virginia, and North Carolina 


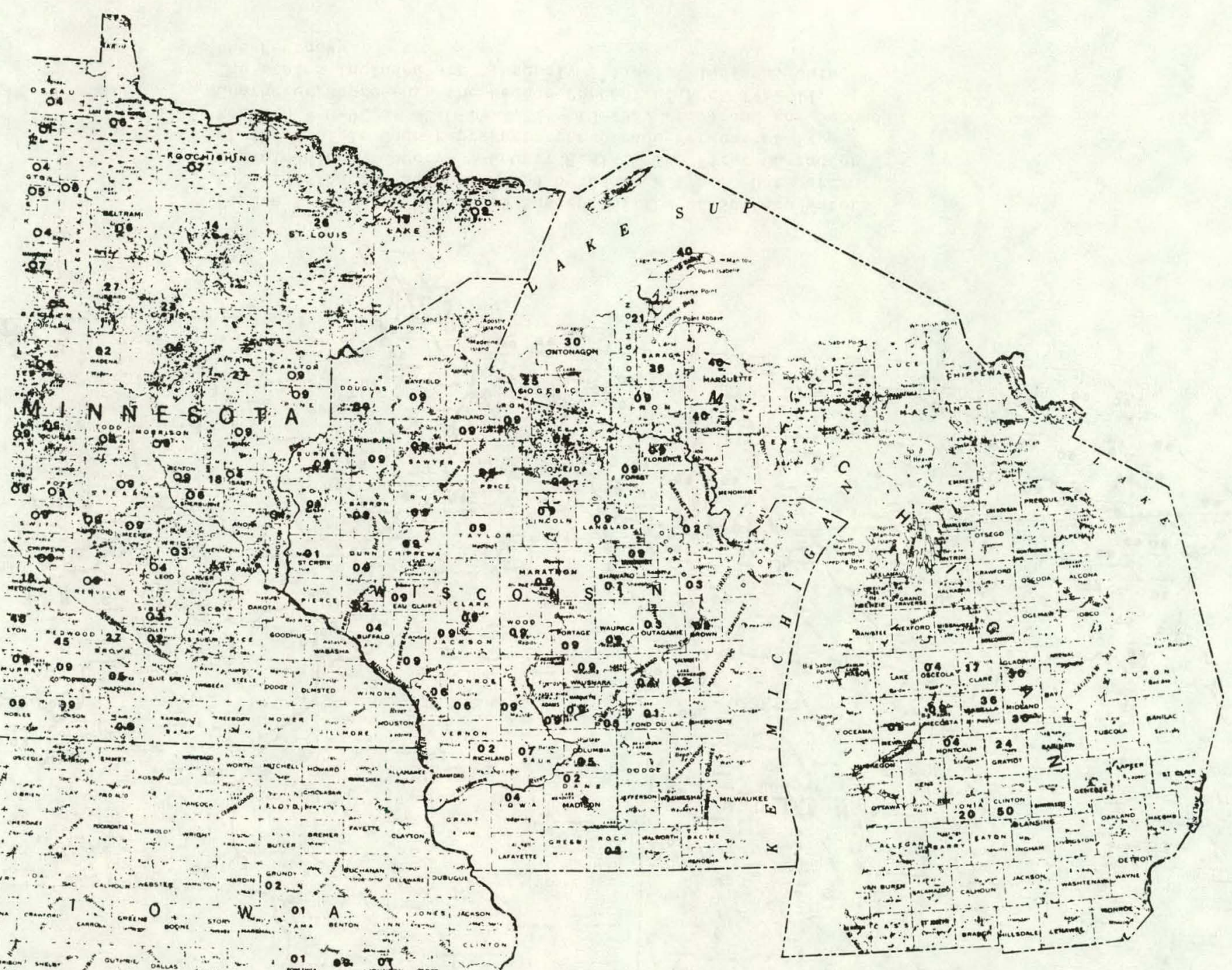

Figure II-4-(c). Predicted Susceptibility of Surface Waters to Acidification as Determined by Bedrock Type. Data are Organized on a County-by-County Basis. The First Character of the 2-Digit Code Represents the Decade-Percent of Type-I Rock ( $0=0-9 \%, 1=10-19 \%, 2=20-29 \%$, etc.) and the Second Character Represents the Decade-Percent of Rock Type II. The States Included are Minnesota (Excluding Western-most Counties), Wisconsin, Michigan, and Iowa 


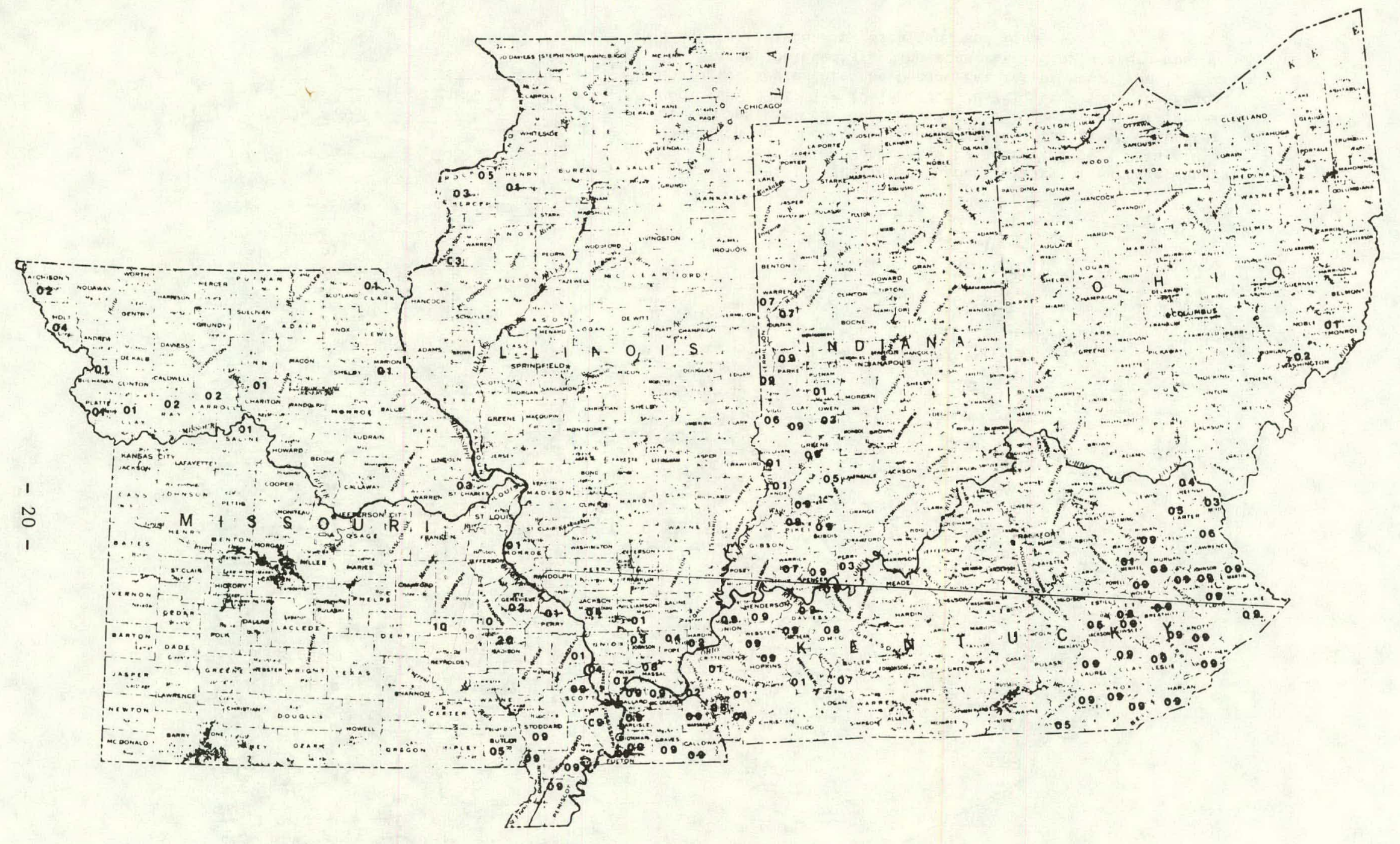

Figure II-4-(d). Predizted Susceptibility of Surface Waters tc Acidifization as Detərmined jy Bedrock Type. Data are Organized on a County-by-County Basis. The First Character of the 2-Digit Code Represents the Decade-Percent of TypeR.cck $(0=5-9 \%, 1=10-1 \mathrm{c} \%, 2=20-29 \%$, etc.) and the Secord Craracter Represents the Decade-Percent of Rock Type II. The States Included are Missouri, Illinois, Indiana, Ohio, ard Kentucky. 


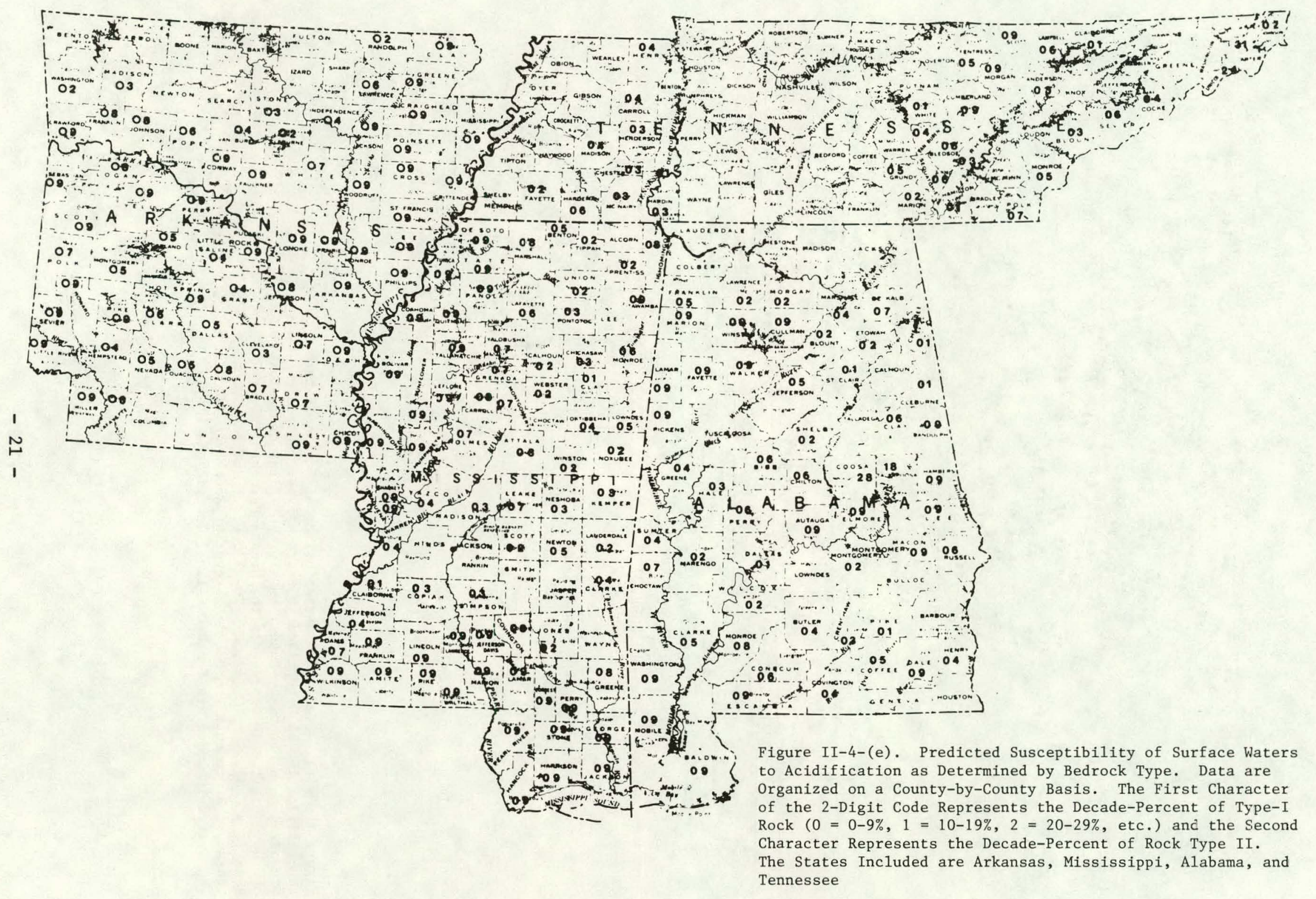




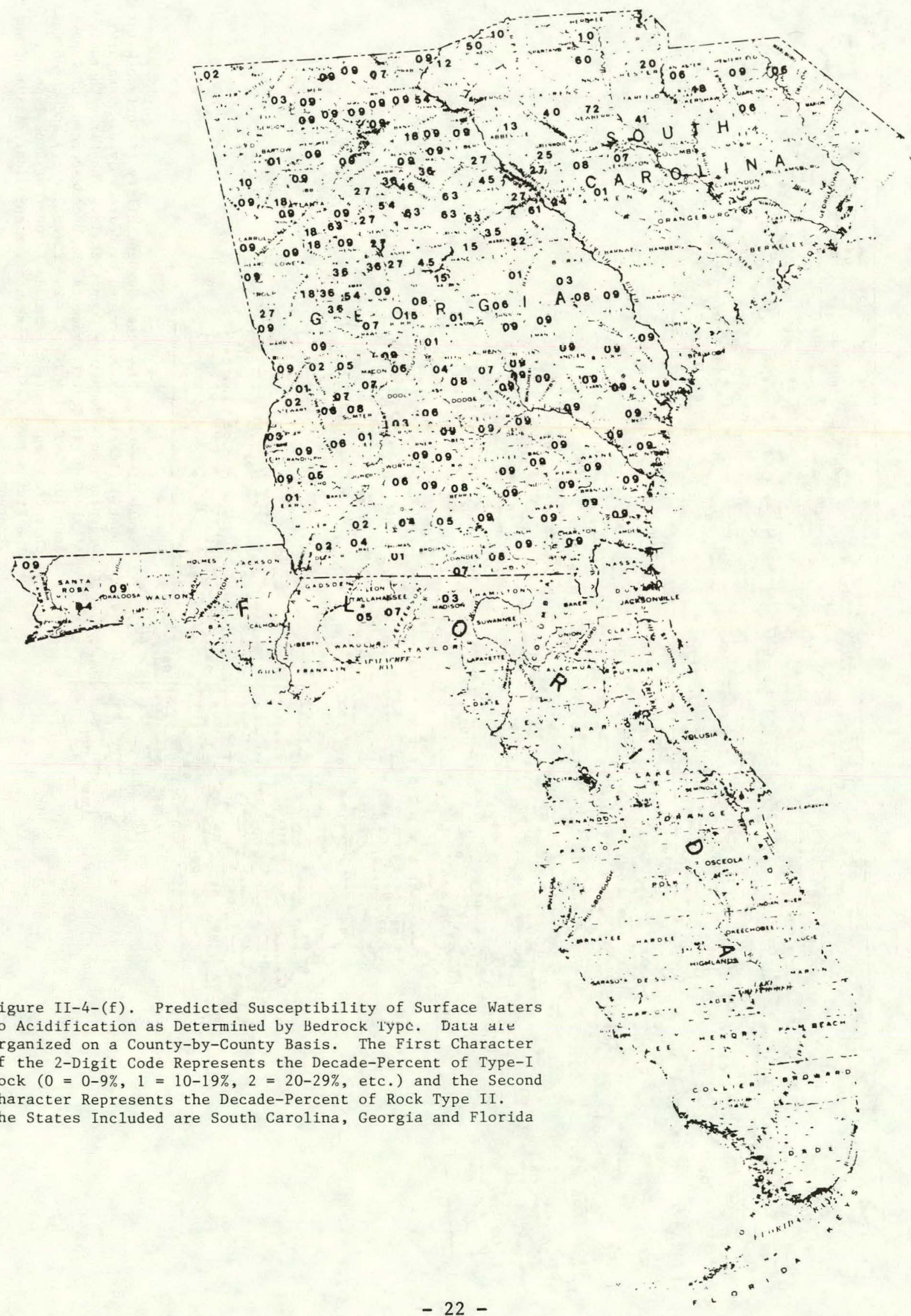




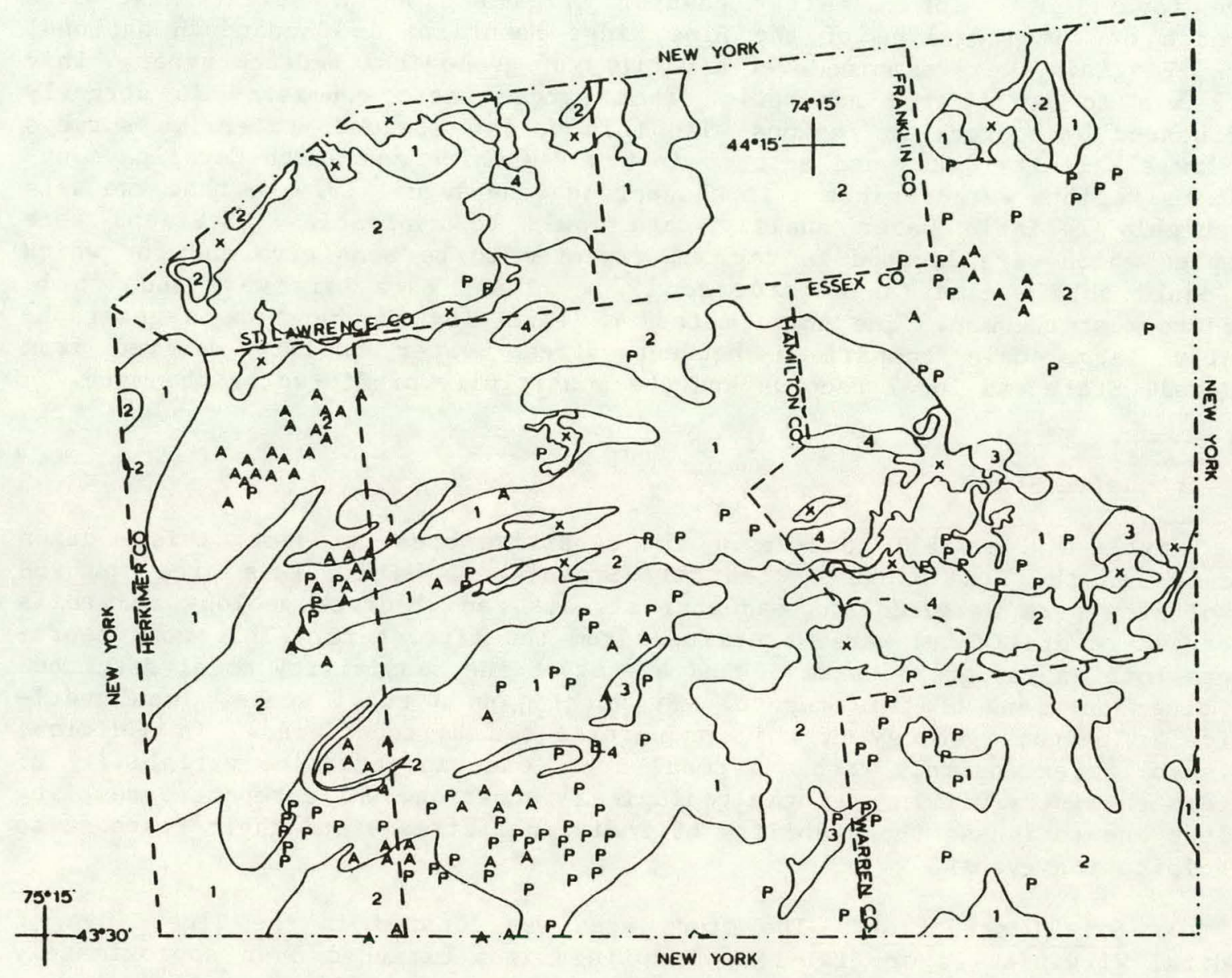

\section{10kulometers}

Figure II-5. High Altitude Lakes (Elevation $>600 \mathrm{~m}$ ) in the Adirondack Mountains of New York Which Have Lust Their Fish Populations (A) Are Shown Superimposed on a Map of Rock-Type I. Lakes Which Still Have Fish are Also Indicated (P) 


\section{VERIFICATION OF THE SENSITIVE AREAS MAP}

The usefulness of the geological delineation of sensitive areas is wholly dependent upon the accuracy with which the geological mapping identifies those areas correctly. To verify the accuracy of the maps, three types of studies were conducted covering geographic regions on three scales. First, an intensive investigation of small headwater streams along a seventy-five mile stretch of the ridgeline of the Blue Ridge Mountains in Shenandoah National Park, Virginia, were sampled over a variety of geological bedrock types. This work was to verify the assumption that stream water chemistry is strongly influenced by bedrock in regions with thin soils. Second, extensive surveys of low alkalinity lakes and streams in New Hampshire and North Carolina mountainous regions were conducted in the period June-August 1979 so that two sets of highly reliable water quality data would be available. Stations were sampled which wcre located in regions expected to be sensitive and for which we could obtain data taken prior to 1970. These data sets were then lu le used to test the map. The third method of verifylng Llie maps was a gengraph1 cally largc-scale comparison between stream water quality derived from Federal, State and local records and Llie sensitivity predicter hy the maps.

\section{A. Intensive Study}

Within the overall context of the sensitive areas project, this section focuses on the Blue Ridge of central Virginia.93 Within this area, $\mathrm{pH}$ and alkalinity were measured on headwater streams, and bedrock geology and soils data (where available) were determined from the literature. This work represents both an integrated example and a test of the sensitivity model described in nther portions of this report. By working on a small scale, local variation in bedrock geology or soil propertles can be considered. Tn addition, by sampling extensively within a small area, one can determine variability of stream chemistry within a single geological formation, while repeated sampling allows one to assess the stability of individual streams and their response to precipitation events.

1. Site Description. The study area was located in the Blue Ridge of central Virginia (Figure III-1). Sampling sites extended over approximately 75 miles along both sides of the ridgeline, with major effort centered along a $20 \mathrm{milp}$ section at the southern end of the Shenandoah National Park. With the exception of data presented in Table III 1, discussiun will be limited tn work carricd out within the smaller area (hereafter referred to as the study area). Chemistry/bedrock trends observed within the large area were consistent with those occurring in the study area. Within the study area, the Blue Ridge occurs as a single major ridge line 2500-4000 feet above sea leve1, with smaller discontinuuus ridges to the east and west. The western slopes are drained by numerous small streams which feed the south fork of the Shenandoah River, while the eastern side is drained by three river systems, the north and south forks of the Moorman's River and Doyles River. Oak-hickory forest covers most of the study area, with pine and hemlock occurring in many of the deeper stream valleys. Nearly all of the sampling stations are in or adjacent to the Shenandoah National Park, and much of the area is designated as wilderness; thus human impact on stream chemistry is negligible. 
Table III-1 pH and alkalinity of streams in major bedrock formations of the Blue Ridge in Central Virginia

\begin{tabular}{|c|c|c|c|c|c|c|c|c|c|}
\hline \multirow{3}{*}{ Format1on } & \multirow{3}{*}{$\frac{\text { Major Rock }}{\frac{\text { Type }}{\text { granodiorite }}}$} & \multirow{3}{*}{$\frac{\mathrm{Age}}{\mathrm{pC}}$} & \multirow{3}{*}{$\frac{\frac{\text { Number of }}{\text { Samples }}}{22}$} & \multicolumn{3}{|c|}{$\mathrm{pH}$} & \multicolumn{3}{|c|}{ Alkalinity $(\mu \mathrm{eq} / \ell)^{\mathrm{d}}$} \\
\hline & & & & \multirow{2}{*}{$\begin{array}{l}\text { mean } \\
6.9\end{array}$} & \multicolumn{2}{|c|}{ range } & mean & & range \\
\hline & & & & & 5.8 & -7.7 & 188 & 40 & -380 \\
\hline Catoctin & meta-basa1t & pC & 18 & 7.0 & 6.5 & -7.65 & 265 & 115 & -655 \\
\hline Lovingston & $\begin{array}{l}\text { biotite quartz } \\
\text { monzonite gneiss }\end{array}$ & $\mathrm{pC}$ & 6 & 6.8 & 6.25 & -7.15 & 227 & 198 & -270 \\
\hline Marshall & $\begin{array}{l}\text { biotite quartz } \\
\text { monzonite gneiss }\end{array}$ & $\mathrm{pC}$ & 3 & 7.0 & 6.8 & -7.0 & 254 & 205 & -305 \\
\hline 01d Rag & granite & $\mathrm{pC}$ & 9 & 6.5 & 5.7 & -6.8 & 96 & 39 & -195 \\
\hline Antietam & quartzite & C & 10 & 5.7 & 5.25 & -6.1 & 7 & -10 & -17.5 \\
\hline $\begin{array}{l}\text { Hampton + } \\
\text { Antietam }\end{array}$ & $\begin{array}{l}\text { quartzite, } \\
\text { shale }\end{array}$ & $\mathrm{C}$ & 19 & 5.7 & 5.1 & -6.3 & 11 & -5 & -35 \\
\hline various & $\begin{array}{l}\text { limestone, } \\
\text { dolomite }\end{array}$ & 0 & 5 & 8.1 & 7.65 & -8.3 & 3600 & 3360 & -3950 \\
\hline
\end{tabular}

a) for a better description, refer to text

b) $\mathrm{pC}=$ Precambrian, $\mathrm{C}=$ Cambrian, $\mathrm{O}=$ Ordivician

c) number refers to number of sampling locations. Where samples were taken at one location on more than one date, an average pll and alkalinity for that location are used. Streams passing through more than one bedrock formation are not included in these calculations, except for streams passing through both the Hampton and Antietam formations,

d) $1 \mathrm{eq} /=.05 \mathrm{ppm} \mathrm{CaCO}_{3}$ 
Soils within the study area fall into two groups; western slopes have coarse thin soils formed from weathering of sedimentary bedrock, while kaolinitic clays are present in large quantities in soils of the eastern slopes. In both cases, soil $\mathrm{pH}$ is low (4.5-5.5), and cation exchange capacity, percent base saturation, and organic content are low in all cases.5,75,87

Bedrock geology in the study area (Figure III-2a, 2b) and other areas of the Shenandoah National Park is based on the work of Gathright, 36 while bedrock in other parts of the survey area are based on Werner ${ }^{97}$ and Bartholomew. ${ }^{7}$ Within the study area, five major bedrock formations occur, these are 1 isted below starting with the oldest and easternmost formation:

1. Pedlar Fm - Massive or layered granodiorite or quartz monzonite. Usually fine to medium-gralned, composed largely of plagioclase and plagioclasemefidspars and quartz.

2. Catoctin Fm - Thick (2000 ft) beds or flows of metamorphosed basalt, composed primarily of feldspar in a matrix of chlorite, actinolite, epidote and pyroxene. Cumuunily includes savifles cuntaining quartz and calcite.

3. Weverton Fm - Thin formation (100-500 ft). Pebbly quartzite beds cemented locally by iron oxides. Interlayered with phyllites.

4. Hampton Fm (Harpers) - Thick beds $(1800-2200 \mathrm{ft}$ ) uf metamorphosed sandstones and shale regularly interbedded, locally iron-cemented.

5. Antletam Fm - (Erwin) Thick (700-1000 ft) bedded, very resistant quartzite.

In general, the Pedlar and Catoctin formations occur in the eastern slopes of the Blue Ridge, while the three clastic rock formations are found on the western slopes. Except.Luns occur at Madison Run and at the southern end of the otudy aren; the significance of these will be discussed later.

In addition to these five formations, several others are found in the initial survey area:

1. Lovingston Formation - augen gncios, in gradational contact with the Marshall Formation. Cowposed primarily of potassic feldspar, quartz, olignclase-andesine, and biotite.

2. Marshall Formation - gray to green, medium grained gneissic granite, in gradational contact with the Pedlar Formation. Major constituents are potassic feldopar, quartz, oligoclase-andesine, and biotite.

3. Old Rag Granite - massive plutonic granite, in gradational or fault contact with the Pedlar Formation. Light gray in color, composed mainly of blue quartz and perthitic microcline.

4. Various Limestone and Dolomite Formations - light gray, mostly fine grained limestone and dolomite. Beds are a few inches to ten feet thick. Occurrence is at the base of the Blue Ridge in the Shenandoah Valley. 
2. Methods and materials. Field samples were collected in $250 \mathrm{ml}$ polyethylene bottles and stored on ice unt1l returned to the laboratory, then refrigerated until analysis. $\mathrm{pH}$ was measured potentiometrically in the field, temperature and conductivity were also measured in the field for each sample. For sequential sampling, samples were collected using an automatic sampler (model S-4040, Manning Environmental Corp.). These samples were stored on 1ce for return to the laboratory, and $\mathrm{pH}$ and conductivity were measured in the laboratory.

Alkalinity and acidity were determined using a double endpoint titration for alkalinity (to $\mathrm{pH}=4.5$ and 4.2 ) and single endpoint ( $\mathrm{pH}=8.3$ ) for acidity. ${ }^{3}$ Titrants were $.005 \mathrm{~N} \mathrm{HCl}$ and $.005 \mathrm{~N}$ NaOH for the respective procedures. Major cations were analyzed by atomic absorption spectrophotometry using an Instrumentation Laboratories 751 spectrophotometer. Major anions and silica were analyzed using standard procedures adopted for Technicon II Autoanalyzer. 32

3. Results and Discussion. Alkalinity and $\mathrm{pH}$ data for the large survey area are summarized in Table III-1, while data for the smaller study area around Shenandoah National Park are presented in Figures III-3 and III-4. Soil chemistry and vegetation are generally similar throughout the survey area, and precipitation chemistry does not vary significantly in the survey area; mean annual $\mathrm{pH}$ is approximately 4.2 .34 Consequently, bedrock geology is interpreted to be the primary factor determining stream chemistry in Virginia Blue Ridge; this conclusion is carried through the remainder of this discussion.

Data presented in Table III-1 indicate a wide range of $\mathrm{pH}$ and alkalinity regimes for the Virginia Blue Ridge. As should be expected, $\mathrm{pH}$ and buffer capacity are highest in those streams originating in limestone and dolomite bedrock. These carbonate rocks react readily with both weak and strong acids, resulting in high bicarbonate concentrations in solution and thus the high $\mathrm{pH}$ and alkalinity observed. Only a few such streams were included in this survey, their purpose belng to put the relatively low buffer capacity of other systems into perspective.

Streams from the four Precambrian, metamorphic formations (Pedlar, Catoctin, Lovingston, and Marsha11) have simllar pH and alkalinity ranges, with near neutral $\mathrm{pH}$ and alkalinities of about $200 \mu \mathrm{eq} / \mathrm{l}\left(10 \mathrm{PPM}\right.$ as $\left.\mathrm{CaCO}_{3}\right)$. While these levels are far below those of the carbonate streams, buffer capacities in this range are sufficient to maintain a stream in good condition except during extreme episodes of acid input. Even in such cases, the changes should be short-lived and relatively minor. Old Rag granite, while quite similar to the Pedlar and Lovingston formations, imparts a significantly lower buffer capacity to streams flowing from it. Long term acidification appears unlikely, but buffer capacity is sufficiently low that these streams probably undergo moderate to oubstantial $\mathrm{pH}$ shifts during acid precipitation events such as those observed in Madison Run (discussed below).

Streams in the clastic bedrock formations (Antietam and Hampton and to a lesser. extent, Weverton) are clearly the most vulnerable to both short and long term acidification. The $\mathrm{pH}$ of these streams is well above that of inctdent precipitation, indicating that some neutralization occurs in the watershed, but the buffer capac1ty of streamwater is minuscule, at best. 
Figures III-3 and III-4 show trends similar to those discussed above, and clearly show the effects of different bedrock formations on the eastern and western slopes of the Blue Ridge in the study area. These figures also show the consequence of a stream passing through several bedrock formations; the $\mathrm{pH}$ and alkalinity of such streams reflect the most reactive bedrock in their watersheds. Madison Run (upper left corner) and several streams at the bottom left side of the figures have much higher $\mathrm{pH}$ and alkalinity than other streams on the western slopes, these differences are presumably attributable to the presence of Catoctin bedrock in their watersheds.

Many of the streams in the survey area were sampled several times during the summer to determine whether there were substantial changes in $\mathrm{pH}$ and alkalinity as a result of seasonal variability or changes in stream discharge. With the exception of Madison Run (see below) there seemed to be relatively little change in chemistry of the streams luvulved.

Tt. should be noted that in all slicedus studicd the carhnnice acid-bicatbonate system was the dominant buffer system. Alkallully titrations showed $\mathrm{pH}$ hehavior indicative of bicarbonate as the principal buffer, and there were no data to suggest the presence of any other buffer.

Following the Initlal survey work in the Blue Ridge, Madison Rum was chosen for more intensive study during the remainder of the study period. This stream has major tributaries flowing out of the Catoctin formation and from clastic bedrock (Weverton and Hampton formations). During initial sampling these tributaries had $\mathrm{pH}$ and alkalinity values typical of the respective bedrock formations. Two kinds of sampling were done; regular (at least biweekly) sampling at several stations on the main stream and tributaries, and also sequential samples (usually 2 hour intervals) taken at various stations diring both dry perfods and during and following individual rainstorms. Sequential sampling during storms has alluwed us to observe the response of these streams to acid precipitation episodes.

Madison Kun is a typlcal waterohed on the western slope of the Blue Ridge, covering about six square miles. Vegetation cover is virtually complete, consisting mostly of oak forest and extensive blueberry coverings, Soils are coarse, thin, and characterized by low $\mathrm{pH}$, cation exchange capacity, and organic matter. The stream system is not gauged, so no budgets can be determined for individual ions.

Total dissolved solids are low in all of the streams of the watershed, typically around $20-30 \mathrm{mg} / \mathrm{l}$. Silica is the major substance in solution, ranging from 7 to $15 \mathrm{mg} / \mathrm{e}$ as $\mathrm{SiO}_{2}$. Bicarbonate is the dominant anton under most conditions, with chloride and sulfate present in lower concentrations on an equivalent basis. Magnesium is the mafor cation in solution with lower concentrations (equivalents per liter) of calctum, sodium, and potassium. Magnesium is a major constituent of the bedrock formations in the watershed, partizularly in the Catoctin formation; so 1 ts abundance in comparison to other cations is not unexpected.

Unlike other streams in the survey area, pronounced changes occurred in both Madison Run (Catoctin bedrock), and its major tributary, White Oak Run (clastic bedrock) during the study period. From early June until mid-August, 
$\mathrm{pH}$ increased in both streams, from 6.05 to 6.5 in Madison Run, and from 5.7 to 6.45 in White Oak Run. Alkalinity showed corresponding increases, from 70 to $150 \mu \mathrm{eq} / \ell$ and 18 to $80 \mu \mathrm{eq} / \ell$ for Madison and White Oak Run's respectively. We are uncertain of the cause of these changes, but changes in stream discharge/ groundwater flow and primary production by mosses and algae growing on bedrock probably both play a role.

In the absence of precipitation, no significant diurnal changes occur in any of the measured parameters on either Madison or White Oak Run. Alkalinity and $\mathrm{pH}$ may undergo very small diurnal cycles on White Oak Run in response to photosynthesis. During major precipitation events, however, substantial changes occur, particularly on White Oak Run. On July 16, slightly less than one inch of rain fell during a thunderstorm over the watershed, resulting in major, but brief changes in water chemistry on White Oak Run (Figure III-5) Both $\mathrm{pH}$ and alkalinity fell substantially, with a corresponding increase in acidity. Nitrate and sulfate levels showed a sharp increase, presumably caused by precipitation input and washoff from leaf surfaces during the storm, while silicon levels declined, probably from dilution of stream water by precipitation. The concentrations returned to previous levels over about an eight hour period.

A second storm, on August 11 and 12, was observed on Madison Run. About 2.5 inches of rain fell over a 24 hour period during this storm, resulting from passage of a frontal system. Major ion analysis for this storm indicate that its effects were minimal, despite the much larger amount of precipitation (rainwater was not collected for chemical analysis during either storm). Slight increases were observed in nitrate and sulfate concentration, and silicon levels declined slightly during the storm, but no change was observed In $\mathrm{pH}$, alkalinity or acidity. Apparently the higher buffer capacity of the stream, combined with more gradual input of acid (inferred from sulfate and nitrate values) allowed the stream chemistry to remain relatively constant throughout the storm.

A third storm, the remnant of Hurricane David, passed through the watershed on September 3, resulting in about 6 inches of rain over a twelve to sixteen hour period. Although the $\mathrm{pH}$ of rain from this storm was rather high (4.9), stream chemistry changed tremendously. Sequential samples on white Oak Run showed a severe depression of $\mathrm{pH}$ to 5.1 , alkalinity decreased to zero, and acidity showed a major increase as bicarbonate was converted to carbonic acid. Thirty-81x hours after the storm, $\mathrm{pH}$ was still well below normal (5.6), and alkalinity was only 12 meq/l, about 20 percent of the pre-storm buffer capac1ty. Madison Run was also sampled following the storm and it too showed much lower $\mathrm{pH}$ and alkalintty $(5.85$ and $60 \mu \mathrm{eq} / \ell)$ than normal.

Data on precipitation events is presented here only to indicate the type of response one might observe in stream chemistry. Clearly, the specific response will depend upon both the pre-storm chemistry of the stream and groundwater in the watershed, and on the composition and magnitude of the precipitation events. In retrospect, Madison Run was probably not an Ideal watershed to choose for concentrated study; the $\mathrm{pH}$ and alkalinity of Madison and White Oak Run seem to show more seasonal variability than occur on other streams. White Oak Run is clearly. not typical of streams flowing from clastic bedrock; by late summer its $\mathrm{pH}$ and alkalinity were well above those of other streams originating in clastic rocks. 
4. Summary of Intensive Study. Within the Blue Ridge of central Virginia, the $\mathrm{pH}$ and buffer capacity of streams varies greatly, with bedrock geology the major factor controlling stream chemistry. With the exception of streams in areas with carbonate-bearing bedrock, buffer capacity is generally low, and virtually nonexistent in streams originating in clastic bedrock. Sensitivity to acidification is presumably greatest in those streams with the lowest buffer capacity, but we have no historical data available to determine whether significant changes in the chemistry of these streams has occurred during recent years. Thus, these data are valuable as baseline data to determine ongoing long-term changes in stream chemistry.

Storm data from the Madison Run watershed clearly demonstrate short-term effects of acid rain on stream chemistry, particularly on White Oak Run. Many streams in the survey area have $\mathrm{pH}$ and buffer capacities significantly lower than occur on white Oak Run; episodic changes in the cliemistry of such streams are probably more pronounced. The effects of such changes on stream fauna may be substantial, 45 but ariè beyond the scupe of this study.

\section{B. Extensive Surveys of Mountalnous Areas of New Halnpslilie and North Carolina}

The states of New Hampshire and North Carolina, separated by over $800 \mathrm{~km}$, recelve acid precipitation with volume weighted mean annual $\mathrm{H}^{+}$concentrations of approximately $114 \mu \mathrm{eq} / \ell(\mathrm{pH} 3.94)$ and $50 \mu \mathrm{eq} / \mathrm{l}(\mathrm{pH} 4.2) .71$ Both states have variable topography with the White Mountains of central New Hampshire and the Blue Ridge mountains of western North Carolina providing terrain with exposed bedrock, grading to reglons of thin soll, then to deep solls. The bedrock also is variable with respect to sensitivity, as can be seen in Fig. III-6 and III-7 with abundant outcrops of slow-weathering, igneous and metamorphic rock. Thus these states were selected as ideal regions in which to test the accuracy of the sensitive areas map. The test consisted of identifying specific sites which have low alkalinity $\left(<200\right.$ Heq $\left.\ell^{-1}\right)$ from historical data, verifying these observations by new sampling, then comparing the locations of these sensitive waters to the map of sensitive areas. The sensitive areas maps were not consulted when selecting sites for sampling, so that the site selection, within the two regions expected to contain sensitive areas was not coupled to the map-making process.

1. Field Methods. The first step in selecting field sites where samples were to be collected, was to examine existing water quality records of the departments of fisheries in each state so that new data could be compared to old data in an analysis of temporal trends, as described below (section IV). Stations which had been previously sampled were then identified on county road maps. Wherever possible, samples were collected at about the same time of year and at the same sites used previously. Sites with alkalindty values greater than $200 \mu \in \mathrm{e}^{-1}$ or pll greater than 7.0 were exrluded, If recent cultural activities such as farming, timber harvest, residential or recreational housing were significant on site or upstream, the site was not included in the sampling. At each location, two samples were taken in $250 \mathrm{~m}$ acid washed polyethylene bottles, rinsed three times in sample water before filling. One sample was acidifled for metal analygis to $a \mathrm{pH}$ of 2 by the addition of lml of $6 \mathrm{~N} \mathrm{HCl}$. These samples were not acidified, but because suspended solids were low, and because most $\mathrm{Ca}$ occurs in dissolved rather than particulate form (70), the amount of $\mathrm{Ca}$ added in particulate form is believed to be negligible. 
The other sample was placed in a cooler filled with ice and kept at or below $4^{\circ} \mathrm{C}$ until $\mathrm{pH}$ and alkallnity measurements could be made (usually every two days). Conductivity in microsiemens was measured with either a Beckman or Presto-tek conductivity bridge. For $\mathrm{pH}$ and alkalinity determinations, a Beckman $\mathrm{pH}$ meter with combination electrode was used. The samples were brought to room temperature before $\mathrm{pH}$ was measured. Alkalinity was determined using Gran's plots. Calcium analyses were performed on acldified samples by atomic absorption spectrophotometry.

2. Results of Field Measurements. The observed alkalinity values (Tables III-1 and III-2) in the ranges $<0 \mu$ eq $\ell^{-1}, 0-50 \mu e q \ell^{-1}, 50-100 \mu e q \ell^{-1}$ and 100-200 ueq $\ell^{-1}$ are shown for each of the stations sampled in Figures III-8 and III-9. These can be compared to Figure III-6 and Figure III-7, the respective state sensitive areas maps. In New Hamshire all of these low alkalinity waters in the regions sampled fall within regions predicted to have Types I and II sensitivity, and in North Carolina all stations fall in Types I or II sensitive areas. Since stations were selected for sampling only if historical data showed them to have low alkalinfties, they were expected to lie in regions underlain by sensitive bedrock. The fact that the geologically based sensitive areas map confirms this expectation constitutes a partial verification of this method of determining sensitive areas.

\section{Large-Scale Comparison}

1. Acidification Chemistry Information Database. Data on Water Chemistry was collated from many Federal, state and local agency sources (Appendix II). Information stored in computerized data bases (e.g. STORET) as well as raw data from field reports gathered from these sources were used to establish the Acidification Chemistry Information Database (ACID) at Brookhaven National Laboratory. Two factors governed the selection of data. Since alkalinity is the dominant factor of water chemistry which determines sensitivity to acidification, all waters with alkalinity values in excess of 500 $\mu e q / \ell$ were excluded. This exclusion selected for moderately to highly sensitive waters and greatiy reduced the amount of data to be included in ACID. Second, the time scale for this project limited us to including about half of the avallable and relevant data which we were able to locate.

A gelleralized daca base management system, SYSTEM 2000 (proprietary system of MRI systems Corp., Austin, Texas) was used for ACID. Analyses were done using a combination of the $\operatorname{CDC} 6600$ and $\operatorname{CDC} 7600$ computers at Brookhaven National Laboratory. Plotting of large scale maps was accomplished with a 36-inch Versatec electrostatic plotter. Some maps and tables were prepared using a FR 80 COM device and many data tables were put onto micro-fiche from the FR 80. Plotting software was developed at BNL and is based on DISSPLA (a plotting software proprietary package of Integrated Software Systems Corp., San Diego).

2. County-by-County Maps. As data is transferred from maps with a scale as fine as $1: 62,500$ to maps at $1: 2,500,000$, fine resolution is completely 1ost. A problem arises in trying to preserve the identity of the isolated sensitive areas. Preserving this information can be accomplished by over-representing the size of the sensitive area. Data in ACID is used to map the current alkalinity and $\mathrm{pH}$ on a county by county basis. Alkalinity values 


\begin{tabular}{|c|c|c|c|c|c|c|}
\hline Table I & \multirow[b]{2}{*}{$\mathrm{pH}$} & \multicolumn{2}{|c|}{$\begin{array}{c}\text { hanges in the chemlsliy } 4 \\
(\mu \mathrm{eq} / 1)\end{array}$} & \multirow{2}{*}{$\begin{array}{l}\text { White oak } \\
\text { Si }\end{array}$} & \multicolumn{2}{|l|}{$\begin{array}{l}\text { Mun, } \\
\text { mg/1 }\end{array}$} \\
\hline Time & & Alkalintty & Acidity & & & \\
\hline 1100 & 6.2 & 56 & 40 & 2.63 & .040 & 4.02 \\
\hline 1300 & 6.2 & 51 & 39 & 2.60 & .036 & 4.02 \\
\hline 1500 & 6.1 & 55 & 39 & 2.60 & .035 & 4.03 \\
\hline 1700 & 6.1 & 54 & 42 & 2.60 & .031 & 4.02 \\
\hline 1900 & 0.05 & 36 & 65 & 1.77 & .334 & 5.6 \\
\hline 2100 & 5.9 & 29 & 70 & 2.24 & .203 & 5.33 \\
\hline 2300 & 5.95 & 37 & 58 & 2.45 & .141 & 4.45 \\
\hline 0100 & 5.95 & 36 & 53 & 2.57 & .147 & 4.40 \\
\hline 0300 & 5.9 & 43 & 53 & 2.52 & .112 & 4.26 \\
\hline 0500 & 5.9 & 41 & 55 & $? .53$ & .082 & 4.24 \\
\hline 0700 & 5.9 & 36 & 55 & 2.53 & .071 & 4.18 \\
\hline 0900 & 5.9 & 34 & 50 & 2.53 & .052 & 4.23 \\
\hline 1100 & 0.15 & 38 & 1,8 & 2.54 & .044 & 4.14 \\
\hline 1300 & 6.2 & - & 41 & 2.54 & .036 & 4.15 \\
\hline
\end{tabular}


were divided into 3 categories: a) ( $100 \mu \mathrm{eq} / \ell$; b) $100-200 \mu \mathrm{eq} / \ell$; and c) > $200 \mu \mathrm{eq} / \ell$ and values at each station for the period (1976-1979) were used for this analysis. The stations included are shown in Figures III-10 and III-11.

Two types of maps are presented:

1. An entire county is assigned the alkalinity category determined by the lowest alkalinity value for the county and shaded according to that value (Figures III-12 and III-13). These maps ensure that areas known to be sensitive on the basis of current water chemistry are identified.

2. A county was assigned the average value of alkalinity, observed at all stations in the county (Figures III-14 and III-15). The existence of low alkalinity waters is frequently lost in these maps, but, when compared to the minimum value maps, the true sensitivity of a whole county is more realistically interpreted.

Maps for all states included in the ACID system are shown in Appendix I.

Some reservations about these maps must be noted. First, it is most unlikely that ACID contains information on all streams of any county; the sample density must be judged by the site maps for each state (Appendix I), recalling that only waters with alkalinities $<500$ peq/ $\ell$ were included in ACID. Second, for the average $\mathrm{pH}$ or alkalinity maps, a single low value may be all that was available for a given county. Again, the site maps (Appendix I) must be consulted. On the other hand, most state water quality data, and especially data in STORET, is biased in favor of downstream locations of water withdrawal for irrigation or municipal use. The water chemistry data from state fisheries agencies is of great value since we suspect it to give a better representation of upstream waters. Inclusion of additional data which we have located from state and local sources into ACID will improve subsequent versions of these maps.

3. Comparing Geologically-Based Maps to Chemistry-Based Maps. The accuracy of the geologically-based sensitive areas maps of North Carolina and New Hampshire (Figures III-6 and III-7) was evaluated by comparing them to the countyby-county maps of current minimum or average alkalinity (Figures III-12 through III-15), which were assumed to be the "correct" maps. (At this stage, the rnunty-by-county maps which show geulogy as a binary number, Figure II-4, were not tested. One cannot distinguish $0 \%$ from $9 \%$ on those maps. They are less precise than the parent maps, such as Figure III-6.) The comparison consisted of first making a prediction of "sensitive" or "non-sensitive" for a particular county based on the bedrock geology alone. A county was predicted to be sensitive if either Type I or Type II bedrock was present, and non-sensitive if neither Type I nor Type II was present. The prediction was then compared to the corresponding surface water alkalinity. A correct prediction of sensitivity was scored if a county contained Type-I or Type-II geological areas and the county alkalinity value was $\leq 200 \mu \mathrm{eq} / \ell$. A correct prediction of non-sensitivity was scored if the county contained no Type-I or Type-II geological areas and the county alkalinity value was $>\overline{200} \mu \mathrm{eq} / \ell$. A false prediction of sensitivity was scored if the county had only Type-I or Type-II geological areas but the alkalinity value was $>200 \mu \mathrm{eq} / \mathrm{l}$. A false prediction 
of non-sensitivity was scored if the county had no Type-I or Type-II geological areas and the alkalinity value was $<200 \mu \mathrm{eq} / \mathrm{l}$. Finally, an indeterminate prediction occurred when a county had Type-I and/or Type-II plus Type-III and/or Type-IV geological areas and alkalinity values $>200 \mu e q / \ell$ were in ACID .

Percentages of these predictions were determined by adding the number of each score class ( 1 .e. In North Carolina correct predictions of sensitivity $=38$ ) and dividing by the number of counties with the appropriate alkalinity score (i.e. in North Carolina $\leq 200 \mu \mathrm{eq} / \ell=42$ ), since the alkalinity score is presumed to be "correct." Thus, in North Carolina,

$$
\text { correct prediction of sensitivity }=\frac{38}{42}=90 \%
$$

Several factors confound the reliability of the geologlcally based map of sensitivicy. The false prediction of sensitivicy may be due to inoufficiant: data in ACID; there may be stleaws of $<200 \mu e q / l$ for which no data have been located in counties where a false prediction of sensitivity was scored. The false prediction of num-sensitivity may be dilp th lust resolution of the genlogical map as contact surfaces were merged and small areas deleted in the mapping process (see Section II of this report). Counties with both sensitive (Types I and II) and non-sensitive (Types III and IV) bedrock may be expected to have waters with alkalinities higher or lower than $200 \mu \mathrm{eq} / \ell$, so absence of 1.nw alkalinity data in this evaluation of the geologically based map of sensitivity results in the indeterminate score.

The degree of agreement is rather good between the maps based on water chemistry and the geologically based map. The results, shown in Table III-3 and III-4, Indicate that the geologically based map predicted the possible sensitivity in $90 \%$ of 42 cuunties which did indeed have sensitive waters in North Carolina and all of such counties in New Hampshire. The "correct" prediction of non-sensitivity was $17 \%$, one of six counties in North Carolina. These cuunties are located in the eastern portion of the state where soll factors are more 1mportant than in the central and western parto of the state. The other five of these six counties, where llic luwast allenlinity in ACTh was $>200 \mu \mathrm{eq} / \mathrm{l}$, were identified by the geologically based map as having Type III or IV bedrock (in some cases, in addition to Type-I and Type-II). The false prediction of non-sensitivity occurred in only $10 \%$ of 42 counties.

In New Hampshire, the guulugically baced map "rorrectly" predicted the sensitivity of all 8 counties with minimum alkalinities of $\leq 200 \mu \mathrm{eq} / \ell$, and a11 5 countles with average alkal1nicy values $\leq 200 \mu \mathrm{cq} / \ell$. A $\overline{11} 10$ rounties of New Hampshire had Type I and Type II geolugical areas and 6 had Type III or Type IV. Both countles with minimum alkalintty greater than $200 \mu \mathrm{eq} / \mathrm{l}$, included Type ITT or IV geology. Thus two indeterminate predictions and no false sensitivity predictions were scored.

Following this evaluation of the predictive capability of bedrock geology, the utility of the less precise binary number geological map was assessed by using it to alsn predict the sensitivity or non-sensitivity of the same counties. Here it was necessary to score a correct prediction of seusitivity If the binary number map indicated the presence of at least 10 percent of Type I or Type II rock in a county and the county alkalinity value was $\leq 200$ $\mu e q / \ell$. This was the case because zero on the binary number map may actually include up to 9 percent of the particular rock type. 
Table III-3. Comparison of the geologically based map of sensitive areas ( $F 1 g$. III-7) to county-by-county maps of alkalinity (FIgs. III-13 and III-15), for 48 of 100 North Carolina counties. See text for definitions of predictions.

\begin{tabular}{lcc}
\hline & $\begin{array}{c}\text { Minimum Alkalinity } \\
\text { Basis }\end{array}$ & $\begin{array}{c}\text { Average Alkalintty } \\
\text { Basis }\end{array}$ \\
$\begin{array}{l}\text { Correct prediction } \\
\text { of sensitivity }\end{array}$ & $90 \%$ of 42 counties & $100 \%$ of 14 counties \\
$\begin{array}{l}\text { Correct prediction } \\
\text { of non-sensitivity }\end{array}$ & $17 \%$ of 6 counties \\
$\begin{array}{l}\text { False prediction of } \\
\text { sensitivity }\end{array}$ & $17 \%$ of 6 counties & $15 \%$ of 34 counties \\
$\begin{array}{l}\text { False prediction of } \\
\text { non-sensitivity }\end{array}$ & $10 \%$ of 42 counties & $38 \%$ of 34 counties \\
Indeterminate & $8 \%$ of 48 counties & $0 \%$ of 14 counties \\
\hline
\end{tabular}

Table III-4. Comparison of the geologically-based sensitive areas map (Fig. III-6) to county-by-county maps of alkalinity (FIgs. III-12 and III-14) for all 10 counties in New Hampshire. See text for definitions of predictions.

\begin{tabular}{lcc}
\hline & $\begin{array}{c}\text { Minimum Alkalinity } \\
\text { Basis }\end{array}$ & $\begin{array}{c}\text { Average Alkalinity } \\
\text { Basis }\end{array}$ \\
\hline $\begin{array}{l}\text { Correct prediction } \\
\text { of sensitivity }\end{array}$ & $100 \%$ of 8 counties \\
$\begin{array}{l}\text { Correct prediction } \\
\text { of non-sensitivity }\end{array}$ & $0 \%$ of 2 counties \\
$\begin{array}{l}\text { False prediction of } \\
\text { sensitivity }\end{array}$ & $0 \%$ of 2 counties \\
$\begin{array}{l}\text { False prediction of } \\
\text { non-sensitivity }\end{array}$ & $0 \%$ of 8 counties \\
Indeterminate & $20 \%$ of 10 counties & $0 \%$ of 5 counties \\
\hline
\end{tabular}


Predictions based on the binary number map (Table III-5) agreed quite well with the contour maps. The principal difference was a tendency for an increase in the indeterminate category and a decrease in false-sensitive.

\section{Map Verification Summary}

The ability of the geologically based map to accurately define areas which may be sensitive to acidification has been verified in three ways. An intensive study within the Shenandoah National Park found stream water $\mathrm{pH}$ and alkalinity along the Blue Ridge to be controlled primarily by bedrock geology. Data obtained during storm events demonstrate that $\mathrm{pH}$ and alkalinity in streams lying on sensitive bedrock fall sharply, presumably in response to inputs of acid precipltation.

Excenslve surveys of curface waters wich alkallullles $(200 \mathrm{bog} / \mathrm{p}$, in North Carolina and New Hampslitre conductod in 1979 , found $83-100 \%$ of these sites were located in Type-I and Type-II sensitive areas, as defined by the sensitive areas map.

Information obtained from numerous sources of raw dula and from computerized data bases, was used to establish the Acidification Chemistry Information Database (ACID). Th1s was used to plot surface water alkalinity on a countyby-county basis. This map, which for testing purposes was considered to be the "correct" map, was compared to the geologically-based map dcfinitions of sensitive areas for each county in North Carolina and New Hampshire. The geologically based sensitive areas map was "correct" for $90 \%$ of the 42 counties in North Carolina, and for $100 \%$ of the 8 counties of New Hampshire, which had alkalinities $\leq 200 \mu \mathrm{eq} / \mathrm{l}$. 


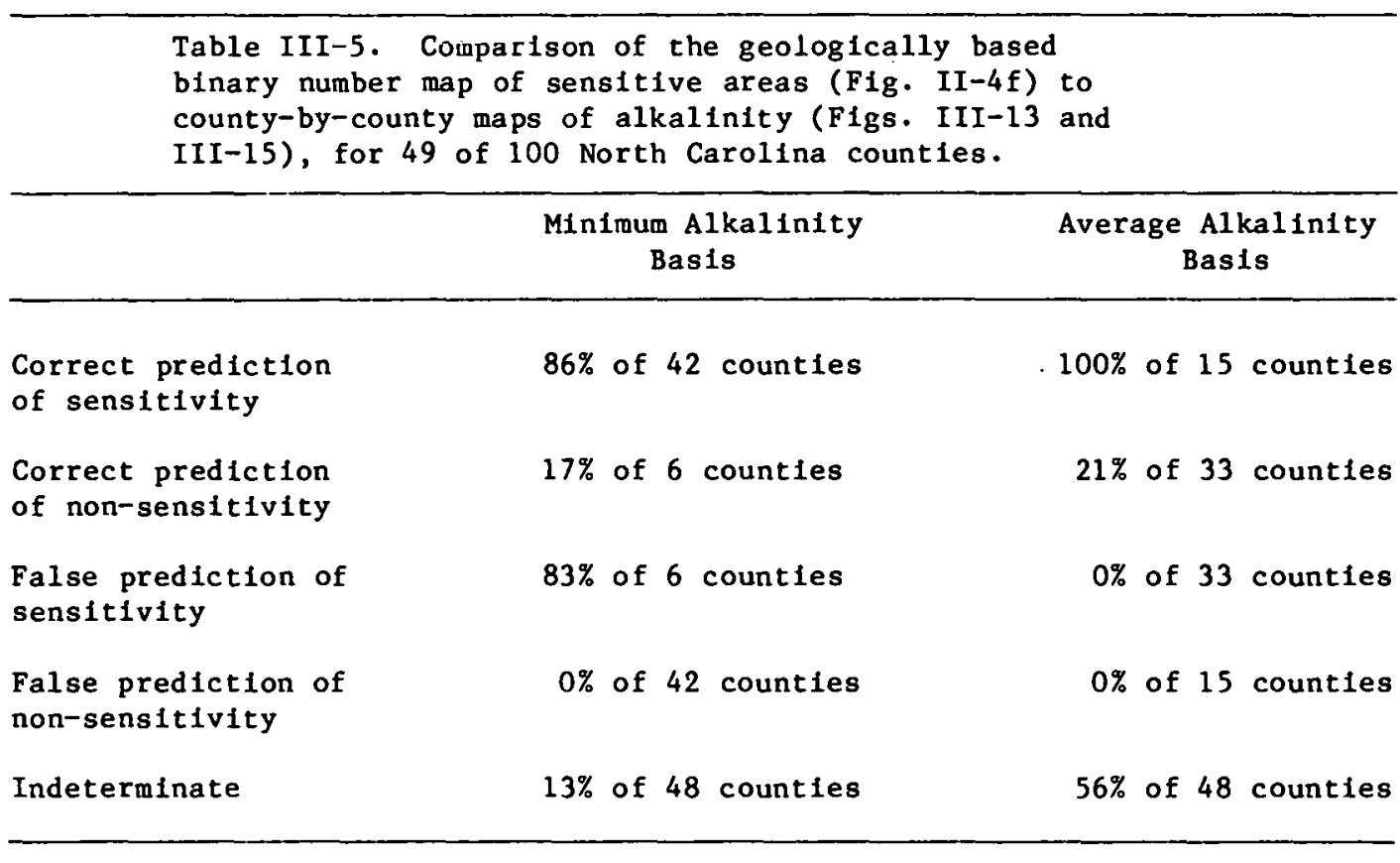

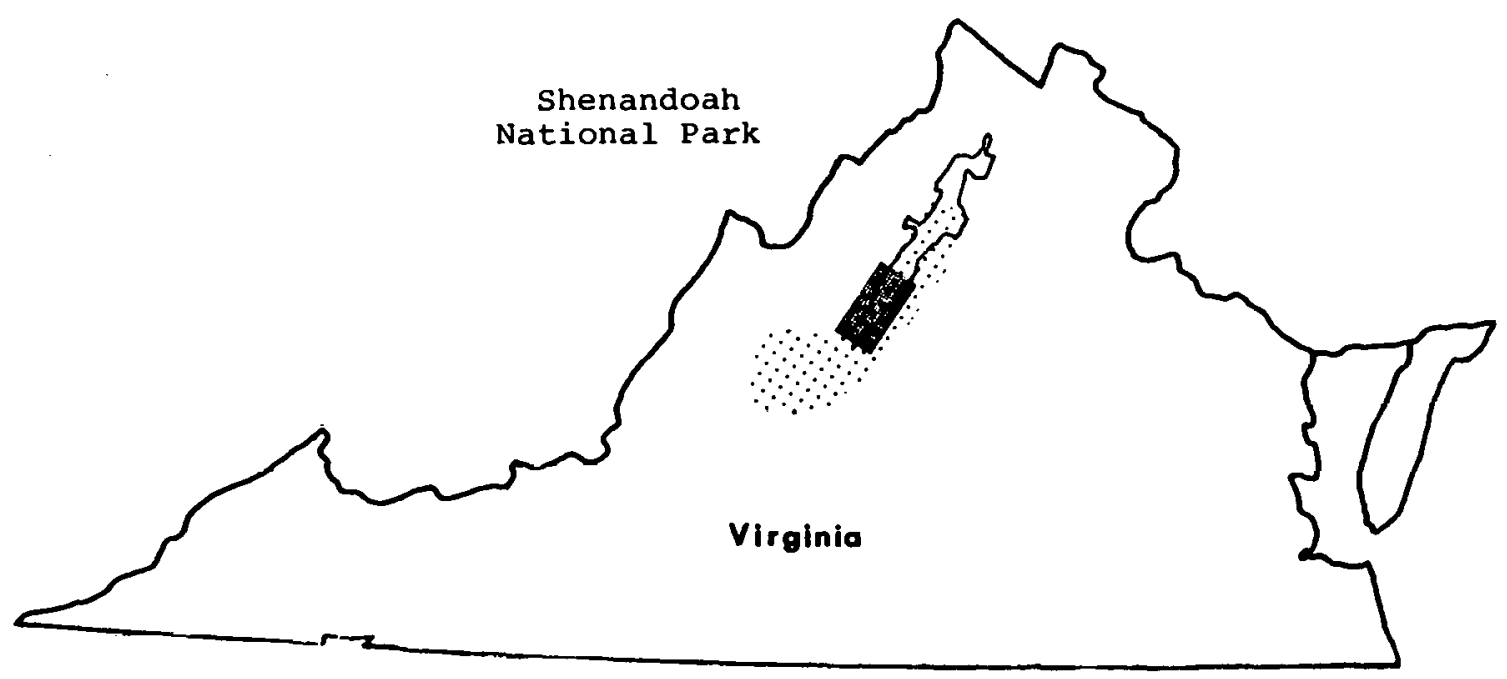

Figure III-1. Location Map of Virginia Showing the Shenandoah National Park, the Original Survey Area (Targe, T,ightly St1ppled Area), and the Smaller Study Area (Darkly Shaded) The Smal1 Study Area is the Same Area as Shown in Figire III-2 to III-4. 


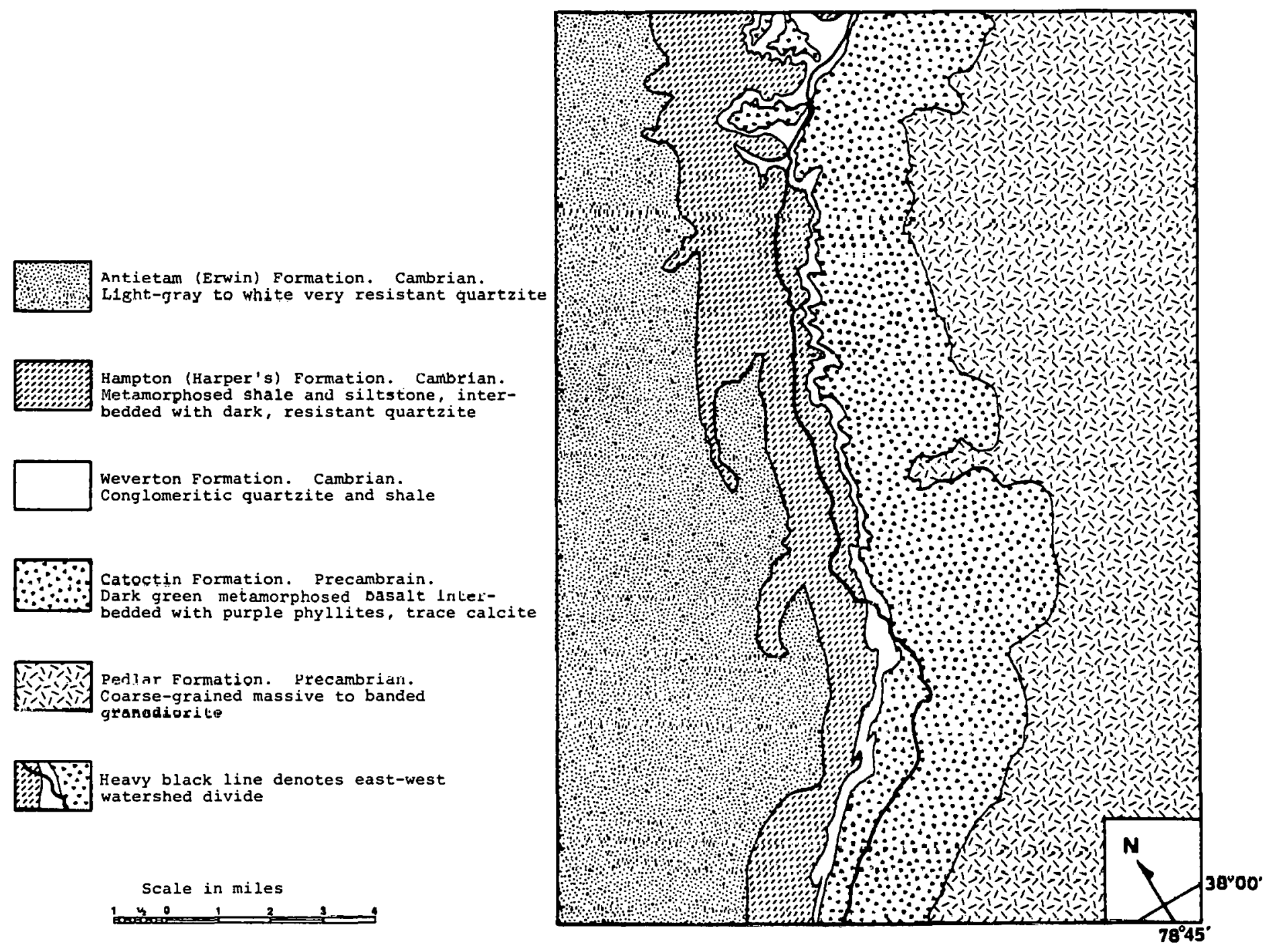

Figure I.IT-2 (a,b), Bedrock Geology in the Study Area in and Adjacent to the Shenandoah Natiunal Park 


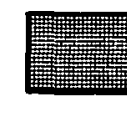

$\mathrm{pH}=5 \cdot 0-5.5$

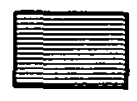

$\mathrm{pH}=5.5-6.0$

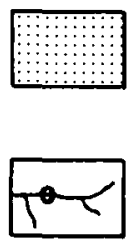

$\mathrm{pH}=6.0-6.5$

pH greater than 6.5

( sample station $=0$ )

Scale in miles

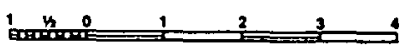

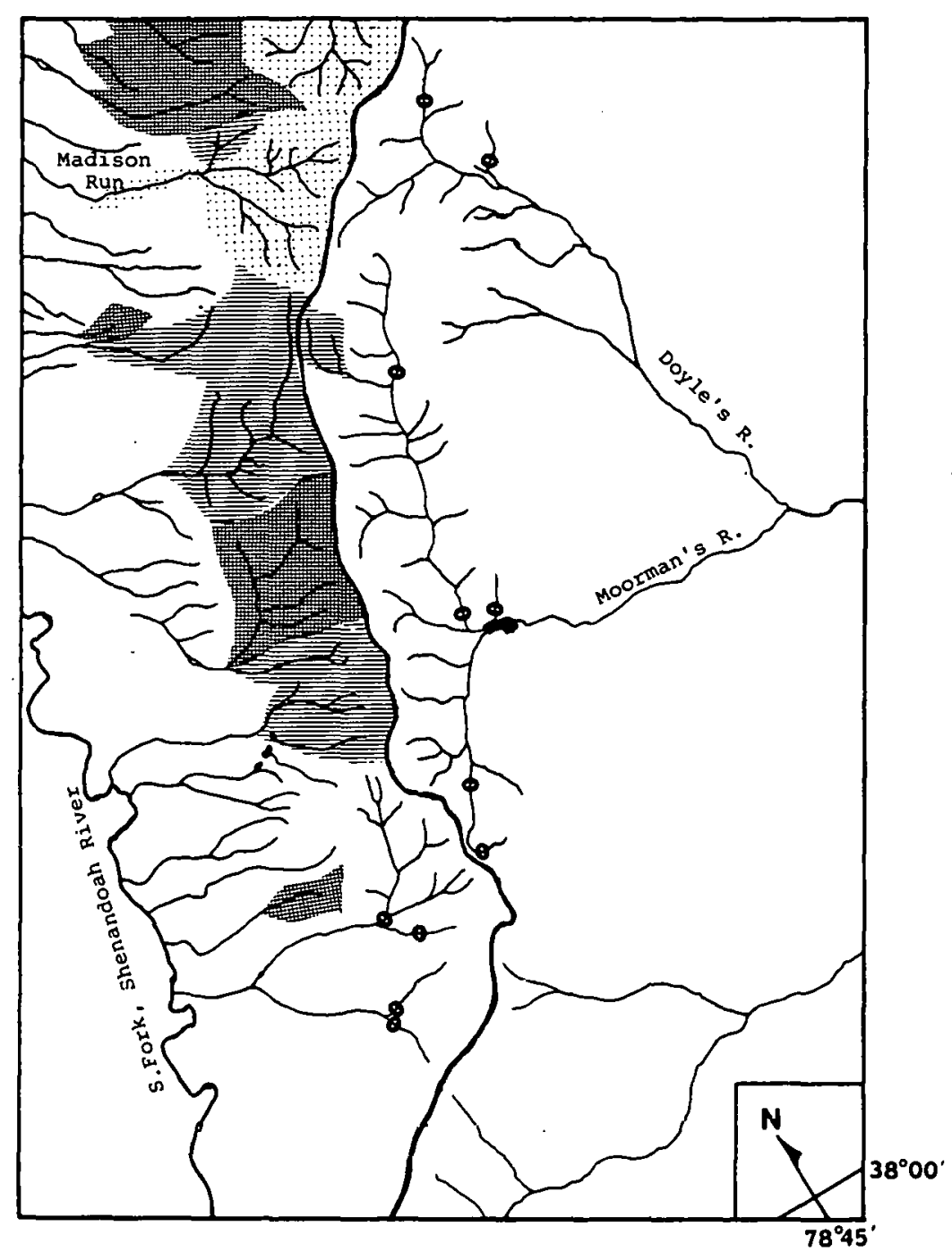

Figure III-3 $(a, b)$. $\mathrm{pH}$ of Streams in the Survey Area. Shaded Areas Represent Watershed Areas Upstream From Sampling Locations 


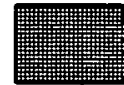

Alkalinity $=0-20 \mu e q / \mathrm{l}$

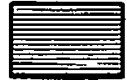

Alkalinity $=20-50 \mu \mathrm{\mu eq} / \mathrm{l}$

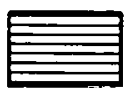

Alkalinity $=50-125 \mu \mathrm{\mu eq} / 2$

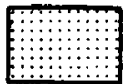

Alkalinity $=125-250 \mu \mathrm{eq} / 2$

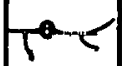

Alkalinity greater than 250 pey/l (somplo ctation $=U$ )

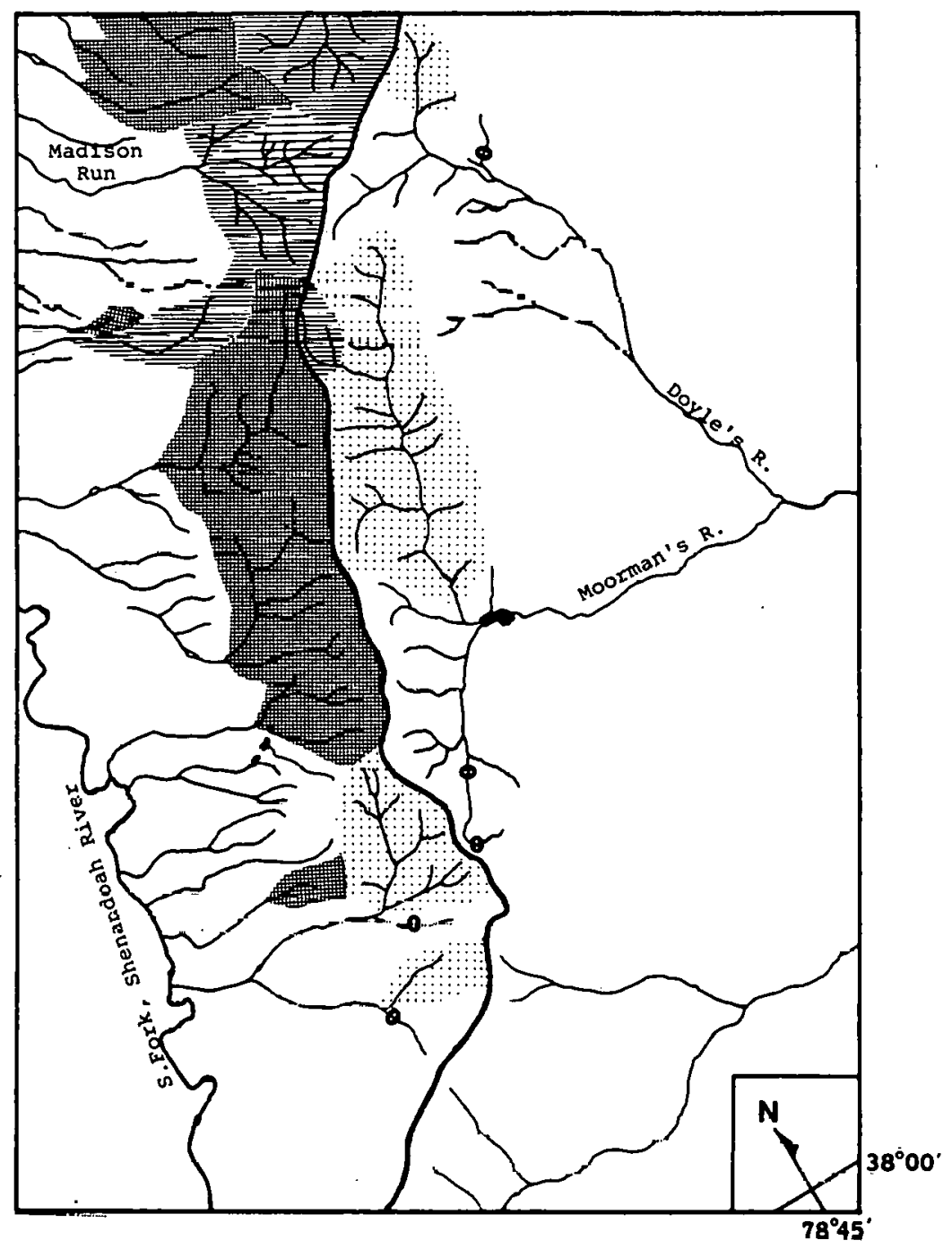

Figure III-4 (a,b). Alkalinity of Stretuis in the Survay Area. Shaded AfH : Rapreacnt Watorshed Areas Ipstream From Sampling Locations 

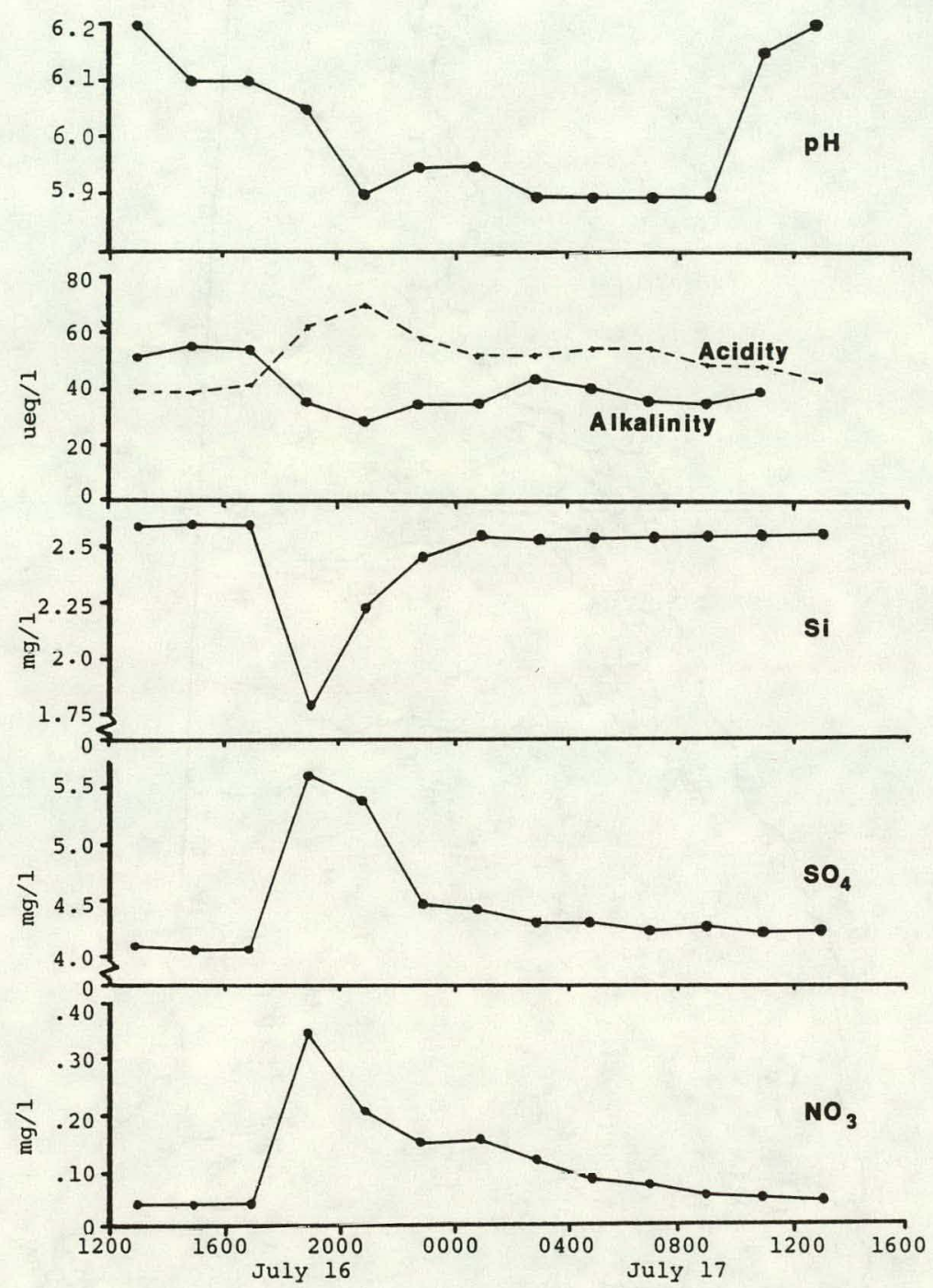

Figure III-5. Changes in Water Chemistry in White Oak Run During the Storm of July 16, 1979. Rainfal1 Occurred Between 1300 and 1900 Hours 


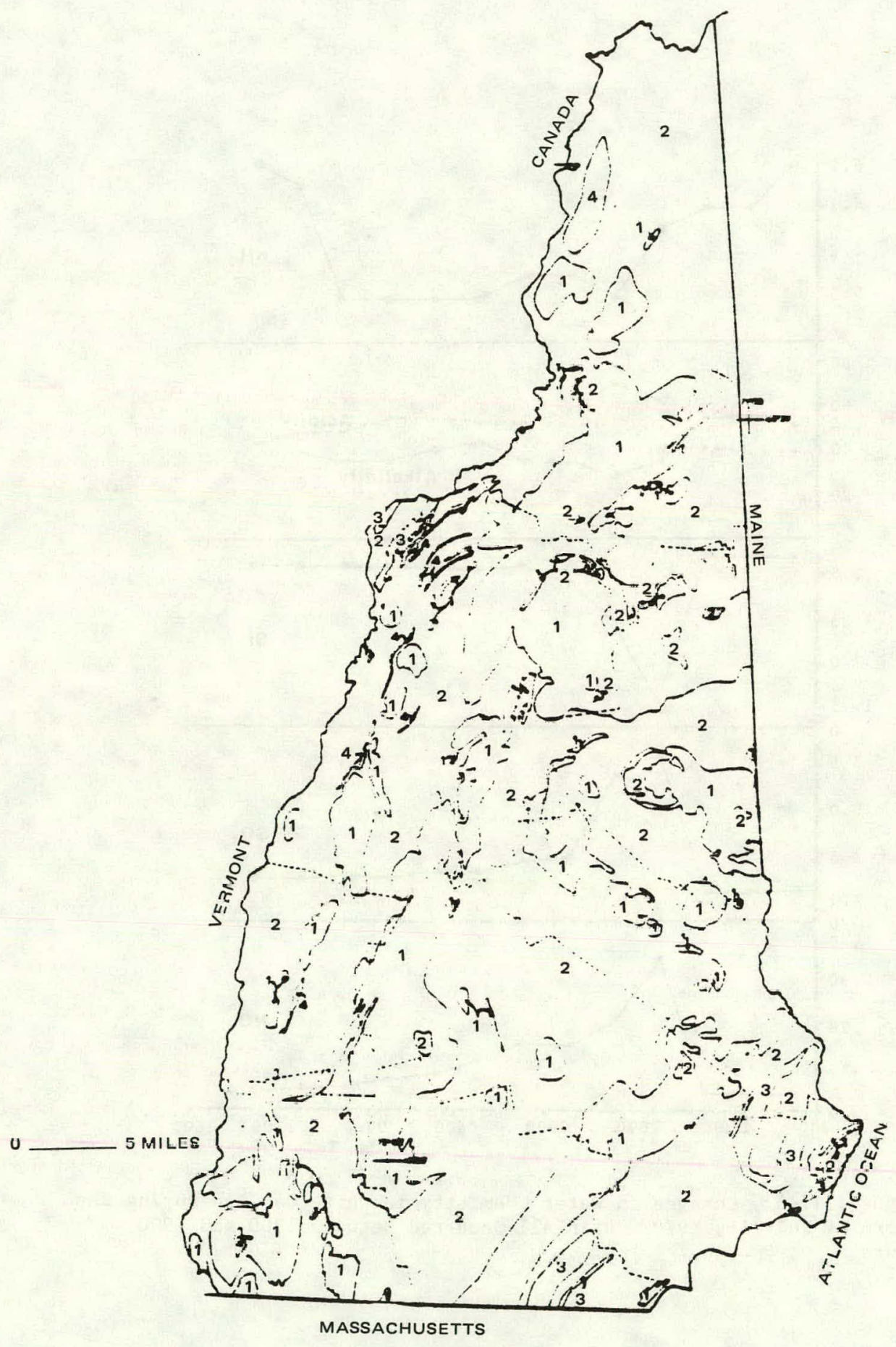

Figure TII-6. Geologically Based Sensitive Areas Map of New Hampshire. Highest Sensitivity (Type-I) is Indicated by 1 on the Map With 2, 3, and 4 Indicating Progressively Less Sensitive Areas. Dashed Lines are County Boundaries 


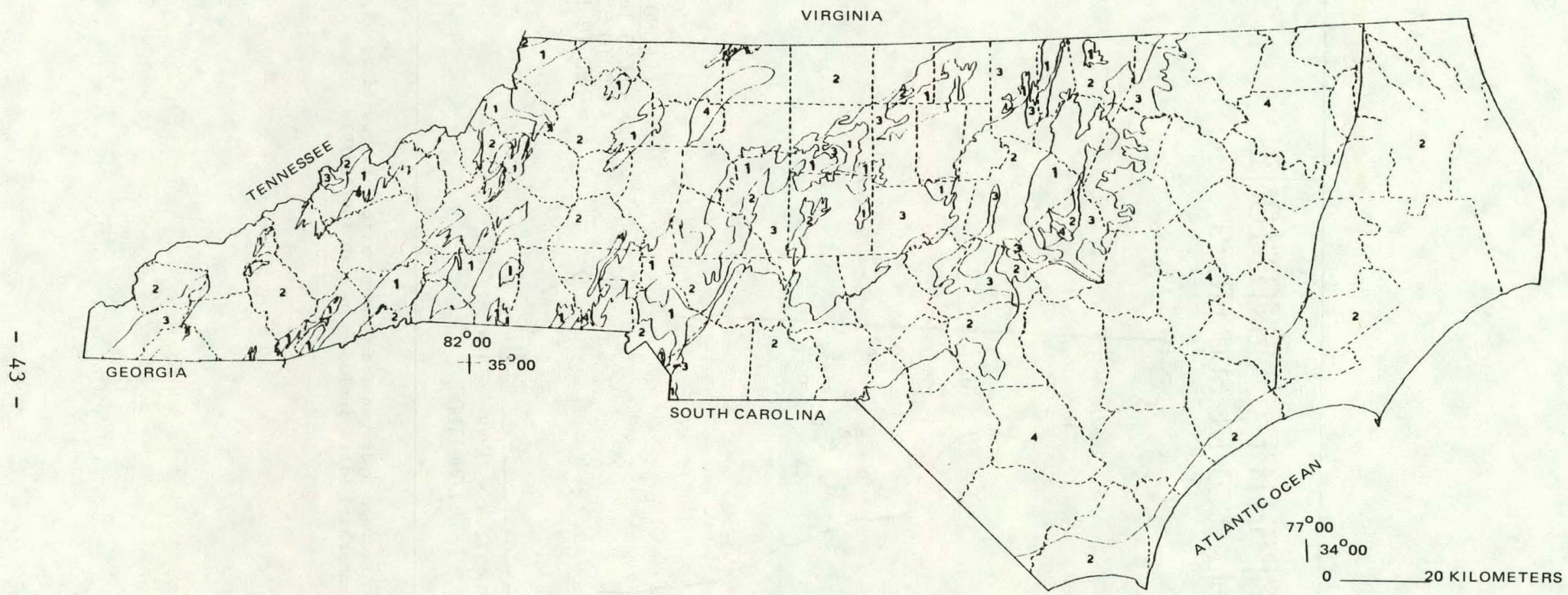

Figure III-7. Geologically Based Sensitive Areas Map of North Carclina. Highest Sensitivity (Type-I) is Indicated by 1 on the Map With 2, 3, and 4 Indicating Progressively Less

Sensitive Areas. Dashed Lines are County Boundaries 
NEW HAMPSHIRE - STATIONS

AVG ALK(UEO/L) SUMMER 79

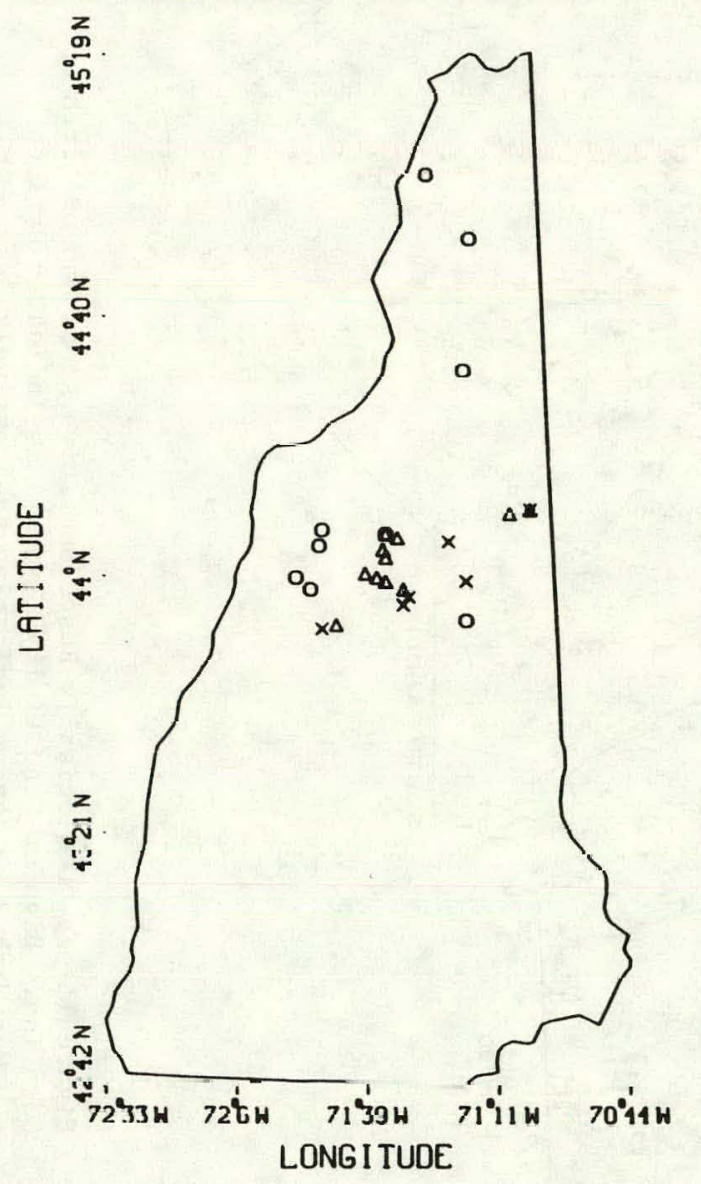

\section{LEGEND}

$x$ - LESS THAN 0

$\Delta=0$ TO 50

0 - 50 T0 100

Figure III-8. Average Hydrogen Ion Concentrations Expressed as pH,

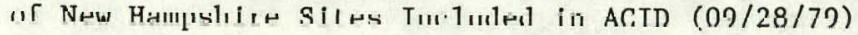




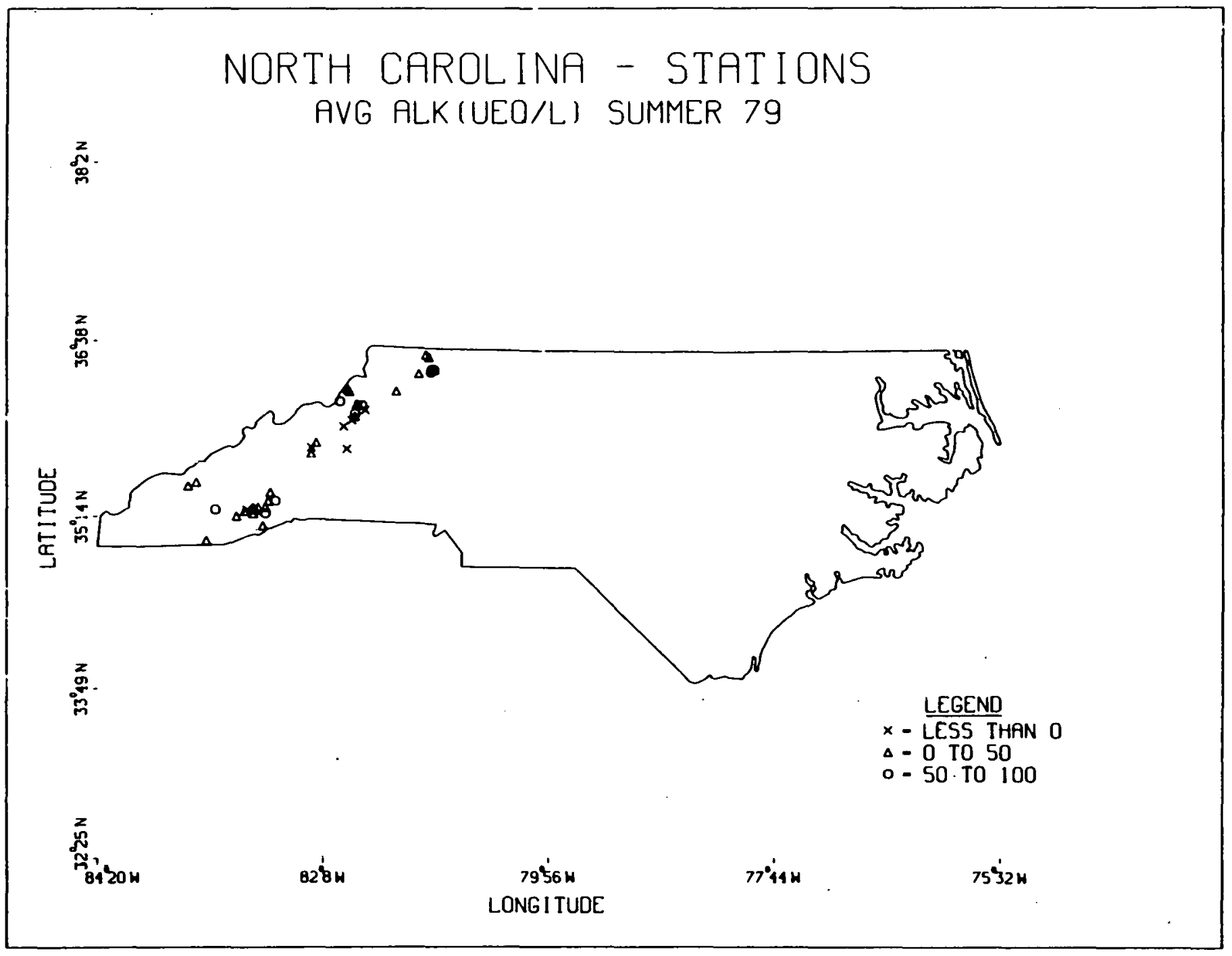

Figure IIT-9. Avcrage Hydrogen Ion Concentrations Expressed as pH, of the North Carolina Sites Included in ACID 


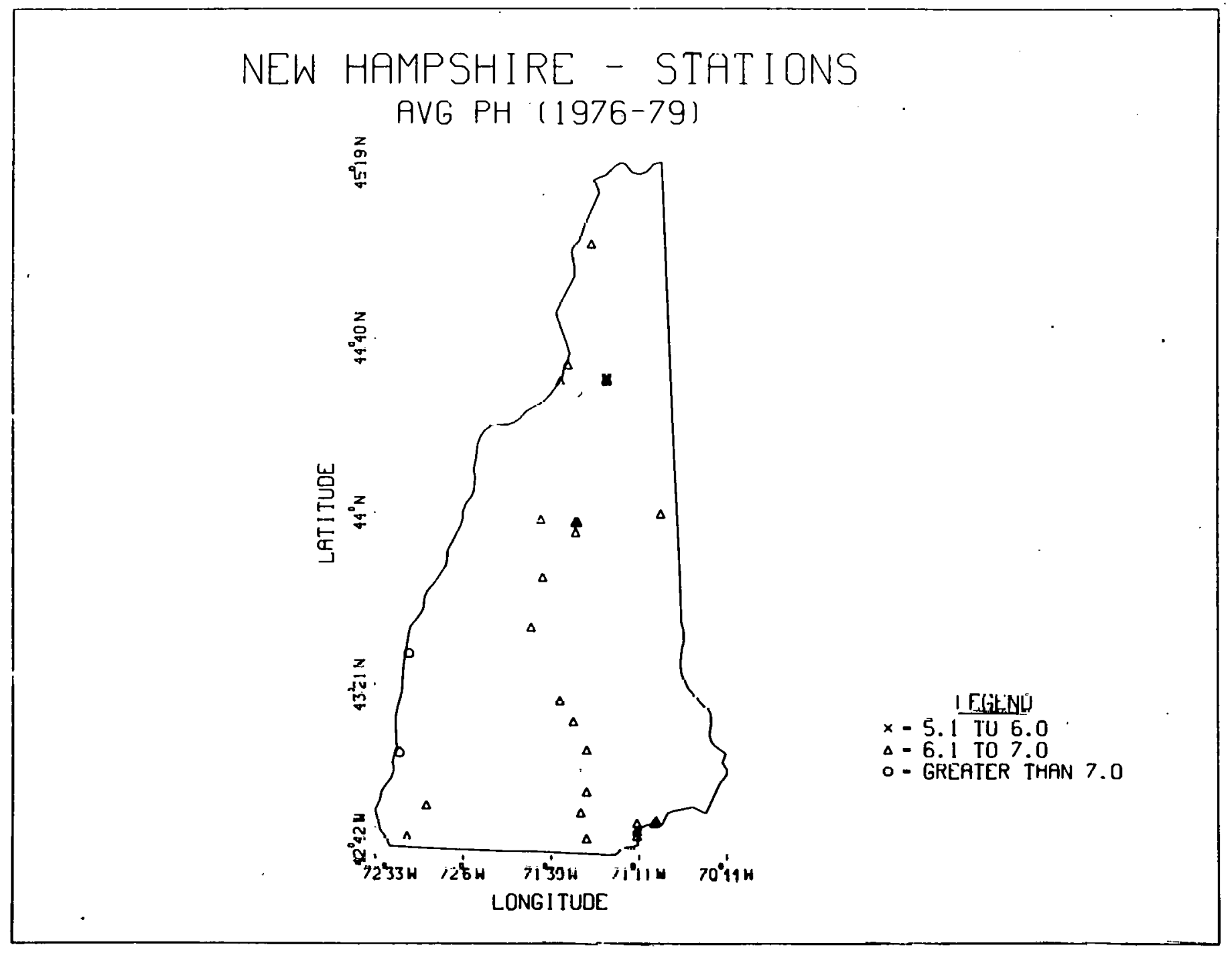

Figure III-10. New Hampshire Counties Shaded According to the Minimum Time-Averaged Alkalinily nhacrvod in Fir.h County. 


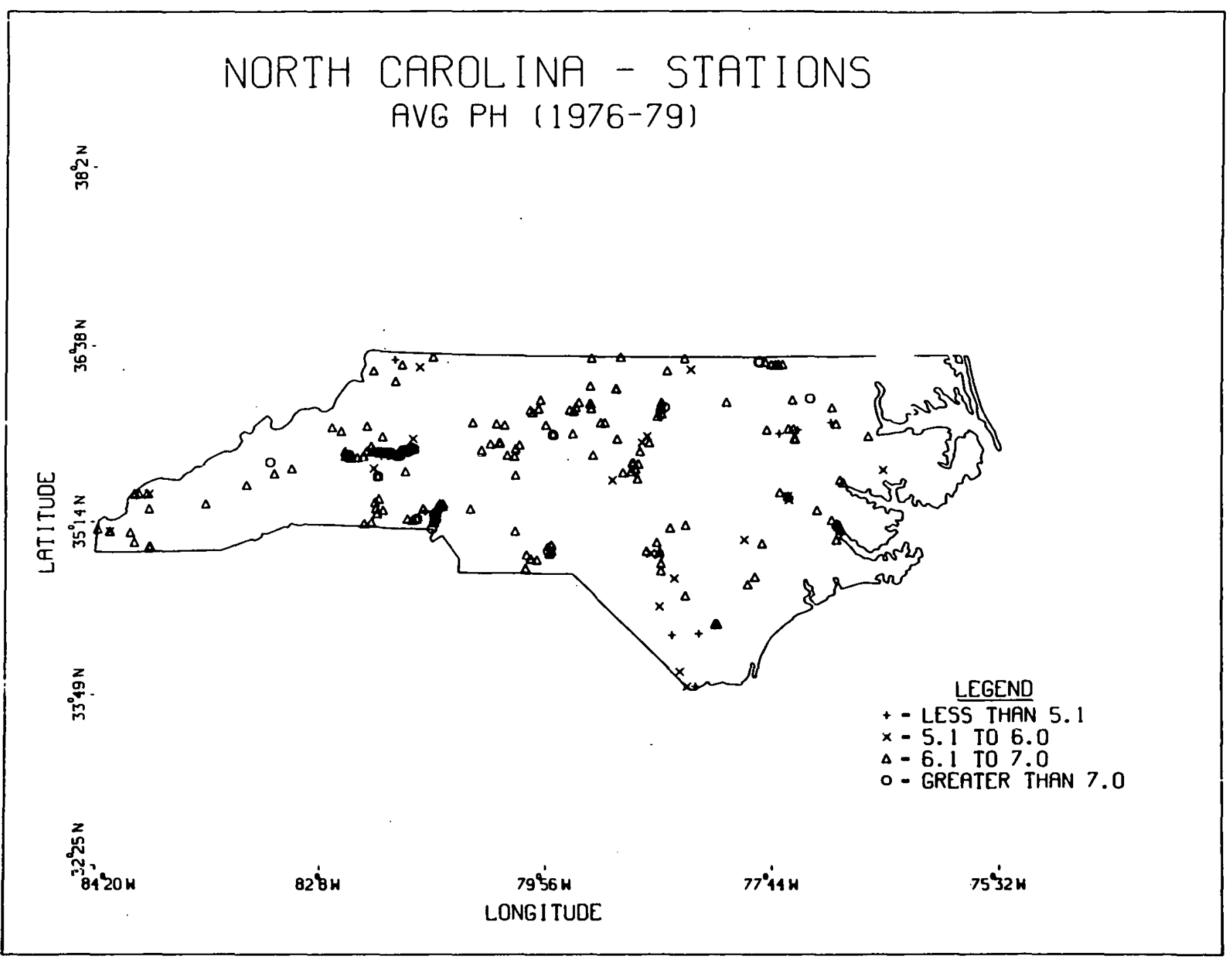

Figure III-11. North Carolina Counties Shaded According to the Minimum Time-Averaged Alkalinity Observed in Each County 


\section{NEW HAMPSHIRE - COUNTIES}

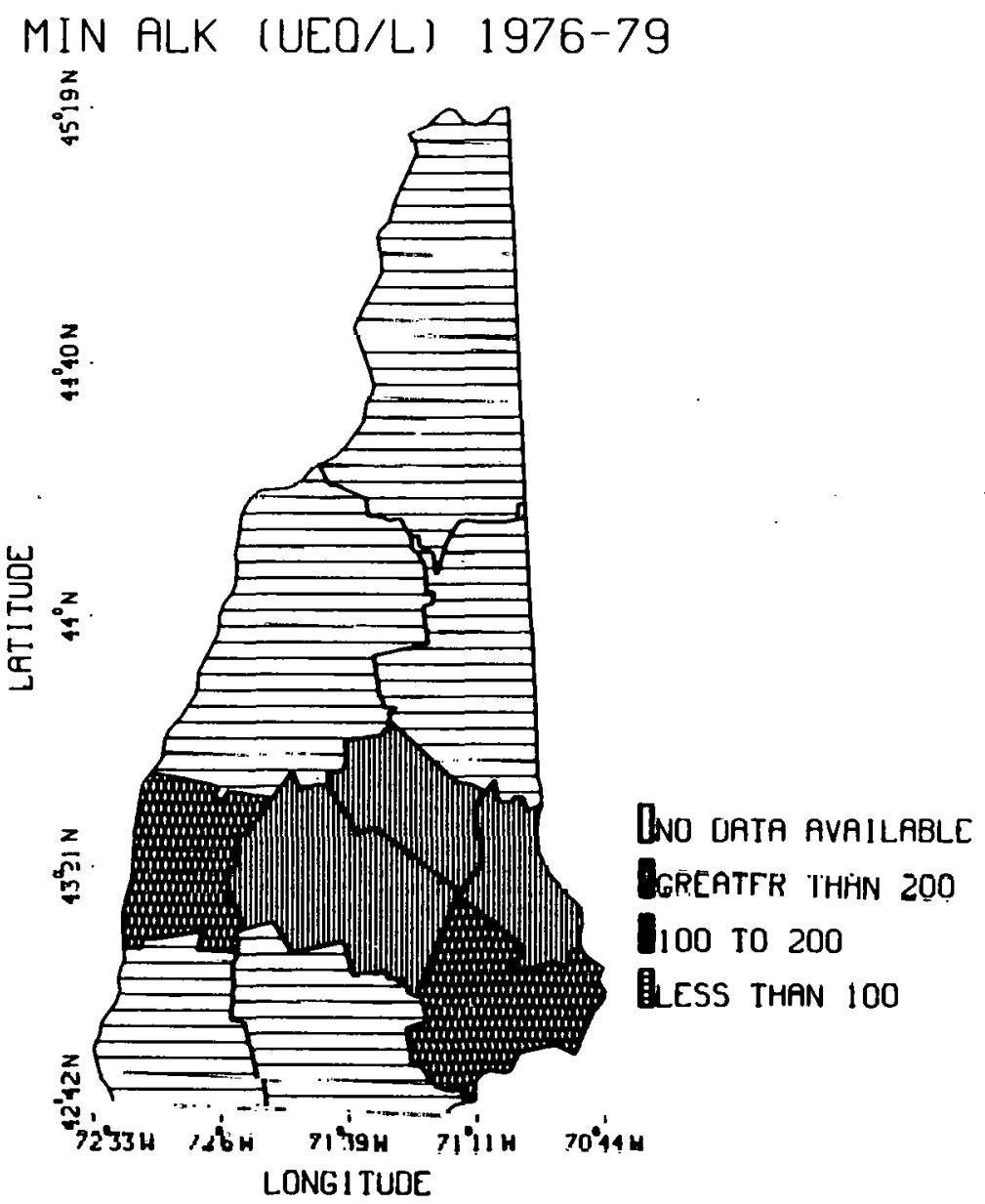

Figure III-12. New Hampshire Countits Ghoded According to the Autrage of $\Lambda 11$ Alkalinity Observations in Each County 


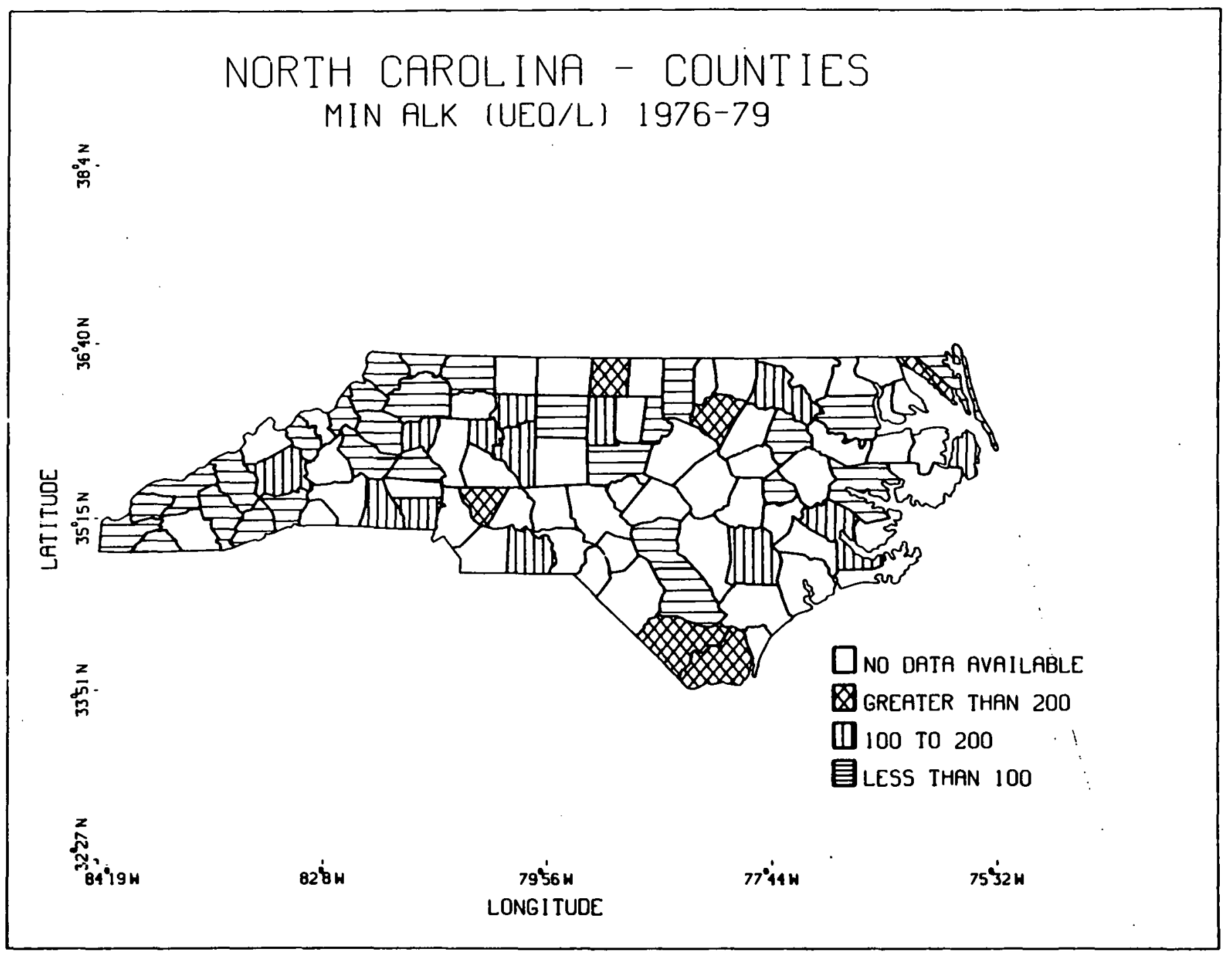

Figure III-13. North Carolina Counties Shaded According to the Average of All Alkalinity Observations in Each County 


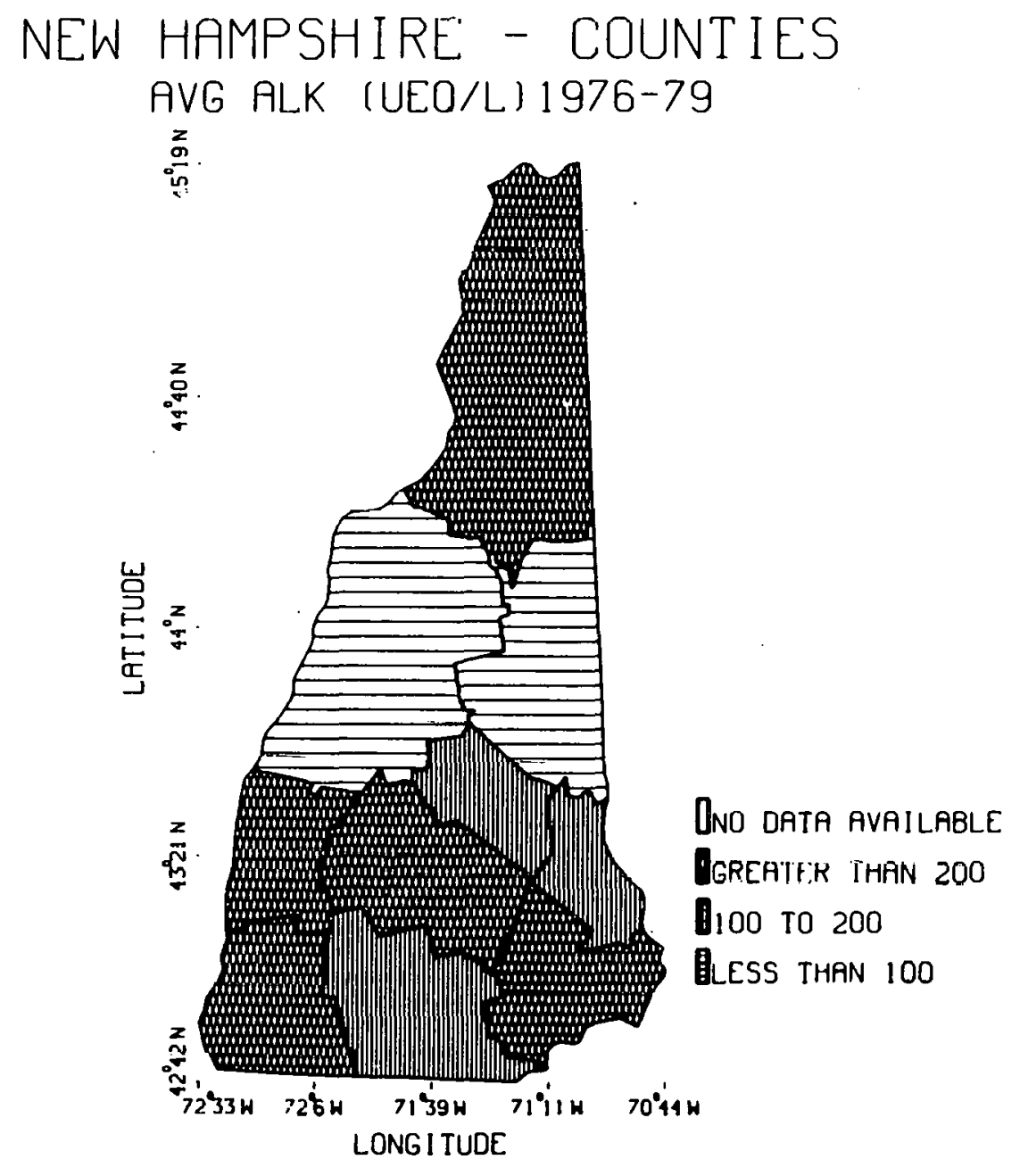

Figure $111-14$. 


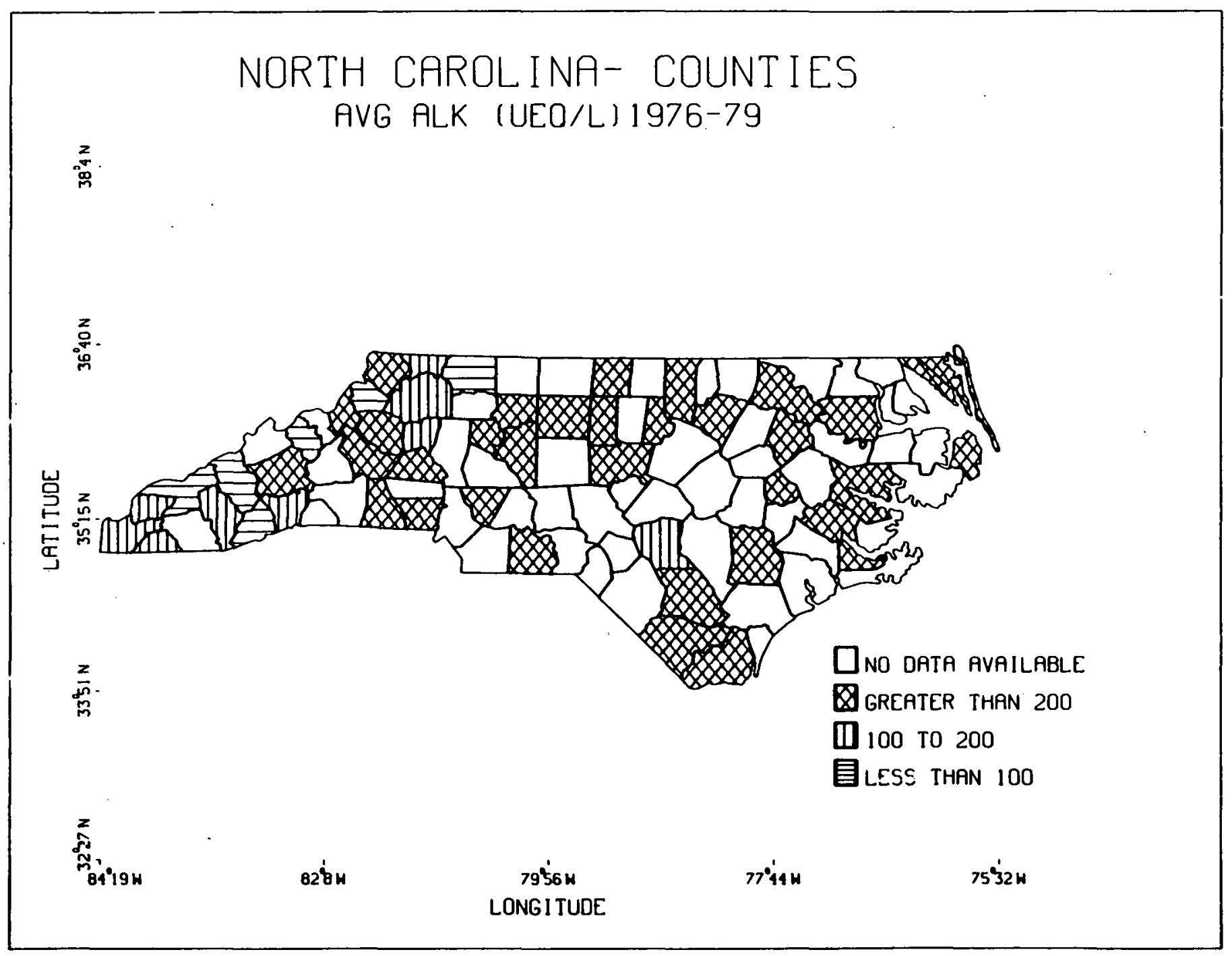

Figure III-15. 


\section{TEMPORAL TRENDS IN PH AND ALKALINITY: VALIDATION \\ OF THE SENSITIVE AREAS MAP}

Historical records have been used to document temporal changes in the chemistry of lakes brought about by acid precipitation.1,23,91,96,104 The sensitive areas map, when combined with projections of trends into future air pollution and rain chemistry, may become useful in predicting which regions will be acidified as the deposition of anthropogenic atmospheric acids increases. The fact that acidification has taken place in regions which are both heavily loaded with anthropogenic acids and are predicted to be susceptible to acidification by the sensitive areas map, is in itself a validation of the predictive value of the map.

Temporal trends in water chemlstry were determlued fus luw alkalinity $\left(<200 \mu e q \ell^{-1}\right)$ sites in New Hampshire and North Carolind by comparing historical records to data obtained in the 1979 extensive surveys described in Section III of this report. Historical data from a variety of Federal, state and local sources for most of the other states were also collated and pre-1970 data was compared to post-1975 data.

\section{A. North Carolina and New Hampshire: Data}

All of the old data obtained for sites resampled in the 1979 field trip to North Carolina came from the North Carolina Department of Inland Fisheries river basin surveys of the early $1960^{\prime}$ s. Table IV-1 lists all of the sampling sites from 1979 with the corresponding earlier data. For the old surveys alkalinity determinations were made using the methyl orange technique, and $\mathrm{pH}$ was determined colorimetrically.

These methods are less precise and less accurate than methods currently used which are potentiometric $\mathrm{pH}$ measurement for $\mathrm{pH}$ and multiple end-point potentiometric alkalinity titration. The problems associated with comparing data sets obtained by these different methods are discussed by $Z i$ mmerman and Harvey. 105 Determination of alkalinity using a flxed end-point titration to pll 4.5 will require 30 to $40 \mu \mathrm{eq} / \ell$ of titrant to remove the free $\mathrm{H}^{+}$in solution at this $\mathrm{pH}$, so alkalinity values are overestimated by this arnount, compared to the multiple end-point method (Gran's plot). The old alkalinity values were corrected, therefore, by subtracting $40 \mu \mathrm{eq} / \ell$. In some cases this has resulted in obviously erroneous alkalinity values for the old (corrected) data, e.g. Boylston Creek, with $\mathrm{pH} 6.9$ and a corrected alkalinity value of -18 ueq/e (Table IV-1). Use of color-indicator solutions for $\mathrm{pH}$ in lowconductivity, poorly buffered waters, will alter the water's $\mathrm{pH}$ and cause a spurious reading. There is no way to syslematically currect these pll errors mathematically. 105

One might also question how accurately a single sample represents the water quality of a lake or stream since $\mathrm{pH}$ and alkalinity of natural waters fluctuate daily and seasonally. It is assumed that daily and sedsonal fluctuation, when sampled during the day and at the same time of year as the previous sampling, are random and normally distributed. Thus, when reasonably 
large populations of sample pairs obtained in synoptic surveys are compared, the positive and negative errors should cancel each other out and regional, temporal trends may be analyzed.

Distributions of apparent $\mathrm{pH}$ and alkalinity changed in the fifteen to nineteen years between samples (Figures IV-1 to IV-6, uncorrected data). Mean hydrogen ion concentration changed from $\mathrm{pH} 6.77$ in the early 1960 's to $\mathrm{pH} 6.51$ in 1979 , an $82 \%$ increase in hydrogen ion concentration. The $\mathrm{pH}$ decreased at $79 \%$ of the sampling sites. The difference between the two sets of values was found to be significant at the 0.02 probability level. Mean alkalinity values have also experienced a significant decline since the early 60's from 116 $\mu \mathrm{eq} / \ell$ (corrected) to $80 \mu \mathrm{eq} / \mathrm{l}$ in 1979 , with $71 \%$ of the 1979 values being lower than the old (corrected) values.

For New Hamphire, extensive sets of old data, collected in the late $1930^{\prime} \mathrm{s}$, were found. No other data for small streams and lakes were located except for some scattered records from the 1970's done by the New Hampshire Water Pollution Control Commission. Unfortunately, this older survey contained only $\mathrm{pH}$ data for small streams, alkalinity titrations were performed only on lakes. It is not known exactly what methods were used to determine $\mathrm{pH}$ and alkalinity for these old surveys, but it was almost certainly some form of colorimetric method for both. The old and new data for New Hampshire is listed in Table IV-2.

A comparison of Figures IV-7 to IV-9 reveals that in New Hampshire there has been an apparent decrease in stream $\mathrm{pH}$ values since the 1930's. The mean hydrogen ion concentration for the old data is $\mathrm{pH} 6.66$ and in 1979 it is 6.12 , a $247 \%$ increase in free hydrogen ion. The $\mathrm{pH}$ values at $90 \%$ of the sampling sites decreased between the 1930's and 1979. Again, the differences between the two sets of data are significant at the 0.02 probability level. of the five sites where old alkalinity data were available, four of the new samples had lower alkalinity.

\section{B. North Carolina and New Hampshire: Discussion}

A method for estimating the expected akalinity value from the observed Ca concentration has been derived by Henriksen 51 , based on water chemistry observations obtained in acidified and non-acidified regions underlain by chemically similar bedrock (described further in section VI of this report). These calculated values, Alkalinity $(\mu \mathrm{eq} / \ell)=1.42 \mathrm{Ca}(\mu \mathrm{eq} / \ell)-32$ for the New Hampshire data are presented in table IV-2. Acidification, defined as loss of alkalinity 51 was estimated by subtracting the expected alkalinity from current measured alkalinity. In this data set, 59 stations had alkalinity values in 1979 which were lower, by an average of $57 \mu \mathrm{eq} / l$, than expected. Regional acidification was thus calculated as $57 \mu$ eq/ $/$ for New Hampshire.

This method of calculating acidification depends on an approximately constant relationship between $\mathrm{Ca}$ and $\mathrm{Mg}$. We found that it could not be applied to the North Carolina data.

In 1955-56 the Blue Ridge area of North Carolina was recelving precipitation with a weighted annual average hydrogen ion concentration of $\mathrm{pH} 4.7-5.2 .69$ By 1972-73, the same area was receiving precipitation with a weighted annual 
average of about $\mathrm{pH} 4.2 .69$ This decline in $\mathrm{pH}$ appears to have caused a significant decline in the $\mathrm{pH}$ and alkalinity of sensitive streams in the Blue Ridge area of North Carolina. If the $\mathrm{pH}$ of rainfall continues to decline in the southeast these streams may experience a continued decline in $\mathrm{pH}$ and alkainity.

The 1979 data for New Hampshire and North Carolina are plotted with Henriksen's 52 empirically derived curve (Fig. IV-10) of $\mathrm{pH}$ versus [Ca], which separates acidified and non acidified lakes (for a more detailed discussion, see section VI). Those points lying above the empirically drawn curve are presumed to have been significantly acidified by precipation and those below presumably have not. None of the samples from North Carolina lie above the curve, while there has been a significant decrease in $\mathrm{pH}$ and alkalinity. Henriksen's curve assumes a constant $\mathrm{Ca} / \mathrm{Mg}$ ratio, which may not be valid for the North Carolina waters, which are underlain by sedimentary and metamorphic rocks. Approximately $54 \%$ of the data points for New Hampshire lie on or above the curve, indicating that many of the sensitive streams and lakes have become significantly acidified. The average $\mathrm{pH}$ of samples in New Hampshire is lower, and their calcium values are higher, than in North Carolina. 
Table IV-1 A comparison of Old and New Data for Heatwater Streams in North Carolina. old alkalinity values were corrected by subtracting $40 \mu \mathrm{eq} / \mathrm{l}$.

\begin{tabular}{|c|c|c|c|c|c|c|c|c|c|}
\hline \multirow[b]{2}{*}{ Stream } & \multicolumn{2}{|c|}{ old } & \multirow[b]{2}{*}{ 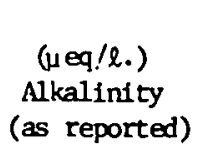 } & \multirow[b]{2}{*}{$\begin{array}{l}\text { Alkallnity } \\
\text { (corrected) }\end{array}$} & \multicolumn{2}{|l|}{$\underline{N E w}$} & \multicolumn{3}{|c|}{ ( Siemens) } \\
\hline & Date & $\mathrm{pH}$ & & & Dete & pH & $\begin{array}{c}(\mu \mathrm{eq} / \ell .) \\
\text { Alk. }\end{array}$ & $\begin{array}{l}\text { Specific } \\
\text { Cond. }\end{array}$ & $\begin{array}{c}(\mu \mathrm{eq} / \mathrm{l} .) \\
\mathrm{Ca}\end{array}$ \\
\hline Roaring Fork & $8-3-61$ & 7.4 & 200 & 160 & $6-29-79$ & 6.7 & 96 & 21 & 41 \\
\hline Little Elkin Creek & $8-24-61$ & 6.9 & 180 & 140 & $6-29-79$ & 7.1 & 206 & 35 & 103 \\
\hline Pike Creek & $8-24-60$ & 7.4 & 180 & 140 & $6-29-79$ & 6.8 & 96 & 18 & 33 \\
\hline Cardner Creek & $7-25-61$ & 6.7 & 200 & 160 & $6-29-79$ & 6.9 & 110 & 19 & 35 \\
\hline Rich Mountaln Creek & $8-25-61$ & 6.9 & 180 & 140 & $6-29-79$ & 6.92 & 128 & 22 & 57 \\
\hline Bullhead Creek & $7-2-61$ & 7.0 & 160 & 120 & $6-29-79$ & 6.89 & 89 & 15 & 26 \\
\hline Fall Creek & $8-14-61$ & 7.2 & 200 & 140 & $6-30-79$ & 6.8 & 80 & 15 & 35 \\
\hline North Harper Creek & $7-19-63$ & 6.9 & 42 & 2 & $6-30-79$ & 6.5 & 46 & 10 & 32 \\
\hline Webb Prong & $7-31-63$ & 6.9 & 176 & 136 & $6-30-79$ & 6.78 & 90 & 14 & 44 \\
\hline Wilson Creek & $7-31-63$ & 6.9 & 2.00 & 160 & $7-1-79$ & 6.5 & 23 & 18 & 88 \\
\hline Boone Fork & $6-6-63$ & 6.9 & 200 & 160 & $7-1-79$ & 6.52 & 73 & 16 & 77 \\
\hline Laurel Fork & $6-6-63$ & 6.7 & 180 & 140 & $7-1-79$ & 6.62 & 116 & 32 & 106 \\
\hline Cold Prong & $6-10-63$ & 6.9 & 140 & 100 & $7-1-79$ & 6.3 & 49 & 14 & 41 \\
\hline Moody's Mill Creek & $6-12-63$ & 6.7 & 180 & 140 & $7-1-79$ & 6.7 & 86 & 19 & $\pi$ \\
\hline Beech Creek & $6-1-63$ & 6.9 & 200 & 160 & $7-1-79$ & 6.8 & 73 & 41 & 108 \\
\hline Buckeye Creek & $6-20-63$ & 6.9 & 160 & 120 & $7-1-79$ & 6.59 & 63 & 26 & 76 \\
\hline Blevins Creek & $6-25-63$ & 6.7 & 200 & 160 & $7-1-79$ & 6.7 & 107 & 50 & 147 \\
\hline Beetree Creek & $6-14-62$ & 6.0 & 36 & -4 & $7-2-79$ & 6.33 & 68 & 12 & 23 \\
\hline Klessee Creek & $6-14-62$ & & 40 & 0 & $7-2-79$ & & 43 & 10 & 24 \\
\hline Cathey's Creek & $6-12-62$ & 6.8 & 100 & 60 & $7-2-79$ & 6.4 & 60 & 10 & 22 \\
\hline Cove Creek & $6-12-62$ & 6.8 & 180 & 140 & $7-2-79$ & 6.5 & 77 & 15 & 44 \\
\hline Davidson River & $6-19-62$ & 6.9 & 120 & 80 & $7-2-79$ & 6.4 & 61 & 14 & 38 \\
\hline Looking Glass Creek & $6-12-62$ & 7.0 & 140 & 100 & $7-2-79$ & 6.34 & 61 & 14 & 40 \\
\hline Cooper Creek & $7-23-61$ & 6.6 & 40 & 0 & $7-3-79$ & 6.2 & 60 & 12 & 26 \\
\hline Deep Creek & $6-28-61$ & 6.7 & 22 & -18 & $7-3-79$ & 6.4 & 70 & 16 & 48 \\
\hline Dick's Creek & $6-27-61$ & 6.8 & 120 & 80 & $7-3-79$ & 6.41 & 77 & 19 & 48 \\
\hline Culowhee Creek & $7-19-61$ & 7.2 & 160 & 120 & $7-3-79$ & 6.8 & 192 & 29 & 111 \\
\hline Tanessee Creek & $7-24-61$ & 6.6 & 80 & 40 & $7-3-79$ & 6.4 & 64 & 13 & 34 \\
\hline Carson Creek & $6-19-62$ & 7.6 & 140 & 10 & $7-4-79$ & 6.4 & 65 & 15 & 38 \\
\hline Williamson Creek & $6-19-62$ & 6.9 & 160 & 120 & $7-4-79$ & 6.9 & 109 & 18 & 43 \\
\hline Turkey Creek & $6-29-62$ & 6.9 & 140 & 100 & $7-4-79$ & 6.7 & 67 & 12 & 29 \\
\hline South Fork Iilll River & $7-17-62$ & 6.8 & 140 & 100 & $7-4-79$ & 6.5 & 57 & 12 & 27 \\
\hline Boylston Creek & $7-9-62$ & 6.9 & 22 & -18 & $7-4-79$ & 6.63 & 145 & 23 & 74 \\
\hline North Mill River & $7-17-62$ & 6.9 & 180 & 140 & $7-4-79$ & 6.6 & 67 & 13 & 31 \\
\hline South Fork Toe River & $6-2-64$ & 6.8 & 180 & 140 & $7-4-79$ & 6.2 & 23 & 10 & 24 \\
\hline Middle Creek & $6-8-64$ & 6.8 & 200 & 160 & $7-4-79$ & 5.99 & 16 & 10 & 21 \\
\hline Locust Creek & $6-9-64$ & 6.8 & 180 & $1.4 n$ & $7-4-79$ & 6.4 & 56 & 13 & 38 \\
\hline South Fork Toe River & $6-2-64$ & 6.8 & 200 & 160 & $7-4-79$ & 6.7 & 84 & 17 & 48 \\
\hline
\end{tabular}


Tabie IV-2 - A comparison D= Jid and New Data for New Hampshire Stneams and Lakes

Old alkallnity väues were corrected by sabtracting $40 \mu \mathrm{eq} / \mathrm{h}$. Old alkalinity values were also estimated from new

Ca concentration usine Fenricksen's milel ${ }^{51}$ and the estimated change in alkalinity calvulated by subtracting new alkalinity from estimated old alkalinity.

\begin{tabular}{|c|c|c|c|c|c|c|c|c|c|c|c|}
\hline Strean or Lake & Date & H & $\begin{array}{l}\text { ( } \mu e q / \ell) \\
\text { Alkalintty } \\
\text { (as reported) }\end{array}$ & $\begin{array}{l}\text { Alkalinity } \\
\text { (sorrected) }\end{array}$ & Date & $\mathrm{pH}$ & $\begin{array}{l}(\mu \mathrm{eq} / \ell) \\
\text { Alkalindty }\end{array}$ & $\begin{array}{l}\text { Speciflc } \\
\text { ( Sienens) } \\
\text { Conductanoe }\end{array}$ & $\begin{array}{l}(\mu \in \mathrm{eq} / \ell) \\
\text { Calcium }\end{array}$ & $\begin{array}{l}\text { Estimated } \\
\text { old Alk. } \\
\text { from Ca }\end{array}$ & $\begin{array}{l}\text { Estimated } \\
\text { Alkalinity }\end{array}$ \\
\hline $\begin{array}{l}\text { Kimball Cr., Coos Co. } \\
\text { Millsfield Pond Bk., }\end{array}$ & $8-1-38$ & 6.6 & & & $7-26-79$ & 6.6 & 196 & 37 & 84 & 87 & +109 \\
\hline $\cos \cos$ & $7-13-37$ & 7.0 & & & $7-26-79$ & 6.9 & 124 & 28 & 155 & 188 & -64 \\
\hline $\begin{array}{l}\text { Horne Brook, Coos Co. } \\
\text { Upper Armonoosuc, }\end{array}$ & $7-8-37$ & 7.0 & & & $7-27-79$ & 6.5 & 151 & 25 & 154 & 187 & -36 \\
\hline $\begin{array}{l}\text { Coos Co. } \\
\text { Jericho Bk. } \cos C_{0} .\end{array}$ & $\begin{array}{l}8-3-37 \\
8-8-37\end{array}$ & $\begin{array}{l}7.0 \\
7.0\end{array}$ & & . & $\begin{array}{l}7-27-79 \\
7-27-79\end{array}$ & $\begin{array}{l}7.0 \\
6.4\end{array}$ & $\begin{array}{l}189 \\
139\end{array}$ & $\begin{array}{l}37 \\
23\end{array}$ & 173 & 214 & -25 \\
\hline Wild River, Coos Co. & $7-7-37$ & 6.8 & & & $7-27-79$ & 6.4 & 39 & 9 & 55 & 46 & -8 \\
\hline Imp Brook, coos co. & $7-6-37$ & 6.8 & & & $7-27-79$ & 6.5 & 63 & 16 & 20 & -4 & +67 \\
\hline $\begin{array}{l}\text { Peabody River, Coos Co. } \\
\text { Nineteen Mile Brook, }\end{array}$ & $7-6-3$ & 6.8 & & & $7-27-79$ & 6.0 & 8 & 44 & 68 & 65 & -57 \\
\hline $\cos \operatorname{Co}$. & $7-6-37$ & 7.0 & & & $7-27-79$ & 6.4 & 63 & 19 & 76 & 76 & -13 \\
\hline $\begin{array}{l}\text { Ellis River, Carroll Co. } \\
\text { Wildcat Brook, }\end{array}$ & $6-28-37$ & 7.2 & & & $7-27-79$ & 6.1 & 85 & 14 & 52 & 42 & +43 \\
\hline Carroll Co. & $6-24-37$ & 7.0 & & & $7-27-79$ & 6.2 & 77 & 20 & $7 \mathrm{D}$ & 67 & +10 \\
\hline $\begin{array}{l}\text { Great Brook, Carroll Co. } \\
\text { Slippery Brook, }\end{array}$ & $6-24-37$ & 7.2 & & & $7-27-79$ & 6.1 & 85 & 14 & 73 & 72 & +13 \\
\hline $\begin{array}{l}\text { Carroll co. } \\
\text { Mountain Pond autlet, }\end{array}$ & $6-24-37$ & 7.0 & & & $7-27-79$ & 6.4 & 78 & 13 & $\mathfrak{q}$ & 83 & -5 \\
\hline $\begin{array}{l}\text { Carroll co. } \\
\text { Paugus Brook, }\end{array}$ & $7-15-37$ & 6.1 & & & $7-27-79$ & 5.6 & 25 & 14 & al & 55 & -30 \\
\hline Carroll Co. & $6-15-37$ & 7.0 & & & $7-29-79$ & 6.2 & 53 & 16 & 100 & 110 & -57 \\
\hline $\begin{array}{l}\text { Swift River, Carroll Co. } \\
\text { Wonalancet Brook, }\end{array}$ & $6-15-37$ & T.C: & & & $7-29-79$ & 6.8 & 155 & 32 & 157 & 191 & -36 \\
\hline $\begin{array}{l}\text { Carroll Co. } \\
\text { Whiteface River, }\end{array}$ & $5-15-79$ & $6 . \varepsilon$ & & & $7-29-79$ & 6.4 & 94 & 29 & 147 & 177 & -83 \\
\hline Carroll Co. & $6-11-37$ & 6.4 & & & $7-29-79$ & 6.3 & 91 & 25 & 118 & 136 & -45 \\
\hline $\begin{array}{l}\text { Cold RIver, Carroll Co. } \\
\text { Atwood Brook, }\end{array}$ & $6-20-37$ & ?.C. & & & $7-29-79$ & 6.4 & 66 & 21 & 107 & 120 & -54 \\
\hline Carsoll Co. & $6-17-37$ & 6.5 & & & $7-29-79$ & 6.3 & 127 & 26 & 195 & 245 & -118 \\
\hline $\begin{array}{l}\text { Bearcamp Brook, } \\
\text { Carroll Co. }\end{array}$ & $6-19-37$ & j.6 & & & $7-29-79$ & 6.3 & 127 & 26 & 197 & 248 & -121 \\
\hline
\end{tabular}


Table IV-2 continued

\begin{tabular}{|c|c|c|c|c|c|c|c|c|c|c|c|}
\hline Stream or Lake & Date & $\mathrm{pH}$ & $\begin{array}{c}\text { ( } \mu \mathrm{eq} / \ell \text { ) } \\
\text { Alkalinity } \\
\text { (as reported) }\end{array}$ & $\begin{array}{l}\text { Alkalinity } \\
\text { (corrected) }\end{array}$ & Date & $\mathrm{pH}$ & $\begin{array}{l}(\mu \propto / / l) \\
\text { Alkalinity }\end{array}$ & $\begin{array}{l}\text { Spectfic } \\
\text { ( Siemens) } \\
\text { Conductance }\end{array}$ & $\begin{array}{c}(\mu \in k) \\
\text { Calcium }\end{array}$ & $\begin{array}{l}\text { Estimated } \\
\text { old Alk. } \\
\text { from } \mathrm{Ca}\end{array}$ & $\begin{array}{l}\text { Estimatæd } \\
\text { Alkalinity }\end{array}$ \\
\hline $\begin{array}{l}\text { White Lake, Carroll co. } \\
\text { Slater Brook, }\end{array}$ & $6 / 21 / 37$ & 6.5 & 100 & 60 & $7 / 30 / 79$ & 5.8 & 4 & 12 & 58 & 50 & -46 \\
\hline $\begin{array}{l}\text { Carrcll Co. } \\
\text { Choconua River, }\end{array}$ & $6 / 12 / 37$ & 6.2 & & & $7 / 30 / 79$ & 6.3 & 119 & 21 & 129 & 151 & -32 \\
\hline Carrall co. & $6 / 15 / 37$ & 7.0 & & & $7 / 30 / 79$ & 6.3 & 89 & 20 & 129 & 151 & -62 \\
\hline Cream Brook, Carroll co. & $6 / 29 / 37$ & 7.2 & & & $7 / 30 / 79$ & 6.3 & 189 & 52 & 188 & 235 & -46 \\
\hline Mat Brook, Carroll co. & $6 / 23 / 37$ & 6.7 & & & $7 / 30 / 79$ & 6.3 & 138 & 26 & 162 & 198 & -60 \\
\hline Mason Brook, Carroll co. & $6 / 21 / 37$ & 6.4 & & & $7 / 30 / 79$ & 6.4 & 138 & 21 & 162 & 194 & -60 \\
\hline $\begin{array}{l}\text { Weeks Brook, Carroll Co. } \\
\text { Upper Kimial Lake, }\end{array}$ & $6 / 26 / 37$ & 7.0 & & & $7 / 30 / 79$ & 6.6 & 79 & 23 & 118 & 136 & -57 \\
\hline $\begin{array}{l}\text { Carroll Co. } \\
\text { Allard Brook, }\end{array}$ & $7 / 23 / 37$ & 6.0 & 140 & 100 & $7 / 30 / 79$ & 6.2 & 42 & 16 & 91 & 97 & -55 \\
\hline Carroll co. & $6 / 29 / 37$ & 72 & & & $7 / 30 / 79$ & 6.5 & 105 & 21 & 95 & 106 & -1 \\
\hline $\begin{array}{l}\text { Hobbs Brook, Carroll Co. } \\
\text { Steam Mill Brook, }\end{array}$ & $6 / 29 / 37$ & 6.8 & & & $7 / 30 / 79$ & 6.2 & 27 & 20 & 98 & 107 & -90 \\
\hline $\begin{array}{l}\text { Carro } 1 \mathrm{Co} \text {. } \\
\text { Olivertan Brook, }\end{array}$ & $6 / 30 / 37$ & 6.4 & & & $7 / 30 / 79$ & 6.0 & 50 & 18 & 79 & 80 & -30 \\
\hline Carroil co. & $6 / 29 / 37$ & 6.4 & & & $7 / 30 / 79$ & 6.1 & 40 & 23 & 95 & 103 & -63 \\
\hline $\begin{array}{l}\text { White Brook, Carroll co. } \\
\text { Downes Brook, }\end{array}$ & $6 / 29 / 37$ & 6.2 & & & $7 / 30 / 79$ & 6.0 & 69 & 23 & 109 & 123 & -54 \\
\hline $\begin{array}{l}\text { Carroll Co. } \\
\text { Douglass Erook, }\end{array}$ & $6 / 29 / 37$ & 6.8 & & & $7 / 30 / 79$ & 5.6 & -10 & 16 & 57 & 49 & -59 \\
\hline Carroll co. & $6 / 29 / 37$ & 7.0 & & & $7 / 30 / 79$ & 6.6 & 134 & 18 & 135 & 160 & -26 \\
\hline $\begin{array}{l}\text { Razor Brook, Carroll Co. } \\
\text { Albany Brcok, }\end{array}$ & $6 / 28 / 37$ & 7.0 & & & $7 / 31 / 79$ & 6.1 & 103 & 30 & 143 & 171 & -68 \\
\hline $\begin{array}{l}\text { Carroll Co. } \\
\text { Sawyer River, }\end{array}$ & $6 / 29 / 37$ & 7.0 & & & $7 / 31 / 79$ & 6.1 . & 127 & 29 & 157 & 191 & -64 \\
\hline Carroll Co. & $6 / 25 / 37$ & 6.8 & & & $7 / 31 / 79$ & 5.8 & 32 & 24 & 101 & 111 & -79 \\
\hline Nancy Broó, Carroll Co. & $6 / 25 / 37$ & 6.4 & & & $7 / 31 / 79$ & 5.8 & 18 & 18 & 79 & 80 & -62 \\
\hline Gibbs Broó, Coos Co. & $7 / 26 / 38$ & 6.8 & & & $7 / 31 / 79$ & 5.1 & -15 & 17 & 52 & 42 & -57 \\
\hline
\end{tabular}


Tajle IV-2 continued

\begin{tabular}{|c|c|c|c|c|c|c|c|c|c|c|c|}
\hline Stream or Lake & Date & $\mathrm{pH}$ & $\begin{array}{l}\text { ( } \mu \text { eq/ l) } \\
\text { Alkalinity } \\
\text { (as reported) }\end{array}$ & $\begin{array}{l}\text { Alkalindty } \\
\text { icorrected) }\end{array}$ & Date & $\mathrm{pH}$ & $\begin{array}{l}\text { ( } \mu \text { eq/ } / \ell \vdots \\
\text { Alkalinity }\end{array}$ & $\begin{array}{l}\text { Specift: } \\
\text { ( Siemens) } \\
\text { Conductanue }\end{array}$ & $\begin{array}{c}(\mu \in \mathrm{q} / \ell) \\
\text { Calcium }\end{array}$ & $\begin{array}{l}\text { Estimated } \\
\text { old Alk. } \\
\text { from } \mathrm{Ca}\end{array}$ & $\begin{array}{l}\text { Estimated } \\
\text { Alkalinity }\end{array}$ \\
\hline $\begin{array}{l}\text { Mt. Pleasant Brook, } \\
\text { Carroll Co. }\end{array}$ & $7 / 25,38$ & 6.9 & & & $7 / 31 / 79$ & 6.0 & 6 & 15 & 79 & 80 & -74 \\
\hline $\begin{array}{l}\text { Clay Brook, Coos Co. } \\
\text { Jefferson Brook, }\end{array}$ & $7 / 25.38$ & 6.9 & & & $7 / 31 / 79$ & 6.2 & 29 & 12 & 40 & 25 & +4 \\
\hline $\begin{array}{l}\text { Coos Co. } \\
\text { South Br. Israel R. }\end{array}$ & $7 / 25.38$ & 6.9 & & & $7 / 31 / 79$ & 6.4 & 18 & 12 & 42 & 28 & -10 \\
\hline $\begin{array}{c}\text { Coos Co. } \\
\text { Deception Brook, }\end{array}$ & 7/13.38 & T.C & & & $7 / 31 / 79$ & 6.3 & 63 & 19 & 103 & 114 & -51 \\
\hline $\begin{array}{l}\text { Coos Co. } \\
\text { Zeland Brook, }\end{array}$ & $7 / 25^{\prime} 38$ & $6 . \varepsilon$ & & & $7 / 31 / 79$ & 6.3 & 150 & 32 & 155 & 188 & -38 \\
\hline Grafton $C$ & $7 / 25 ! 38$ & $6 . \varepsilon$ & & & $7 / 31 / 79$ & 6.4 & 64 & 25 & 119 & 137 & -73 \\
\hline $\begin{array}{l}\text { Little River, Coos So. } \\
\text { Tucke= Brook, }\end{array}$ & $7 / 26 ! 38$ & 6.4 & & & $7 / 31 / 79$ & $6: 4$ & 52 & 16 & 94 & 101 & -49 \\
\hline GEafton Co. & $7 / 14 / 38$ & 6.8 & & & $7 / 31 / 79$ & 6.4 & 123 & 222 & 449 & 607 & -484 \\
\hline Reel 3rook, Grafton Co. & $7 / 14 / 38$ & 0.8 & & & $8 / 1 / 79$ & 5.9 & 52 & 6 & 98 & 107 & -55 \\
\hline $\begin{array}{l}\text { Ham Branch, Grafton Co. } \\
\text { Black Brook, }\end{array}$ & $7 / 14 / 38$ & 5.8 & & & $8 / 1 / 79$ & 6.2 & 150 & 37 & 164 & 201 & -51 \\
\hline Grafton Co. & $7 / 12 / 38$ & 0.8 & & & $8 / 1 / 79$ & 6.3 & 111 & 29 & 107 & 120 & -9 \\
\hline $\begin{array}{l}\text { Lost River, Grafton Co. } \\
\text { Walker Brook, }\end{array}$ & $8 / 27 / 39$ & 5.5 & & & $8 / 1 / 79$ & 6.1 & 43 & 124 & 105 & 117 & -74 \\
\hline $\begin{array}{l}\text { Grafton Co. } \\
\text { Cascade Brook, }\end{array}$ & $8 / 27 / 39$ & 5.7 & & & $8 / 1 / 79$ & 6.4 & 76 & 21 & 75 & 75 & +1 \\
\hline $\begin{array}{l}\text { Grafton Co. } \\
\text { Hancock Branch, }\end{array}$ & $8 / 2 \pi / 39$ & 5.1 & & & $8 / 1 / 79$ & 6.5 & 116 & 64 & 150 & 181 & -65 \\
\hline Grafton Co. & $8 / 2 \subseteq / 39$ & 6.7 & & & $8 / 1 / 79$ & 6.0 & 65 & 36 & 116 & 133 & -68 \\
\hline $\begin{array}{l}\text { Cedar Brook, Grafton Co. } \\
\text { E. Branch Penigewasset, }\end{array}$ & $8 / 2 c / 39$ & $6 . ?$ & & & $8 / 1 / 79$ & 5.9 & 63 & 28 & 97 & 106 & -43 \\
\hline Grafton co. & $8 / 2 \varepsilon / 39$ & 6.7 & & & $8 / / 79$ & 6.4 & 51 & 24 & 107 & 120 & -69 \\
\hline $\begin{array}{l}\text { Baker River, Grafton Co. } \\
\text { Merrill Brook, }\end{array}$ & $8 / 25 / 39$ & 6.7 & . & & $8 / 2 / 79$ & 5.4 & 33 & 18 & 57 & 49 & -16 \\
\hline Grafton Co. & $8 / 26 / 39$ & 6.3 & & & $8 / 2 / 79$ & 6.7 & 173 & 38 & 148 & 178 & -5 \\
\hline
\end{tabular}




\begin{tabular}{|c|c|c|c|c|c|c|c|c|c|c|c|}
\hline \multirow[b]{2}{*}{ Stream or Lake } & \multicolumn{10}{|c|}{ Table IV-2 continued } & \multirow[b]{2}{*}{$\begin{array}{l}\text { Estimated } \\
\text { Alkalinity }\end{array}$} \\
\hline & Date & $\mathrm{pH}$ & $\begin{array}{l}\text { ( } \mu e q / \ell) \\
\text { Alkalinity } \\
\text { ías reported) }\end{array}$ & $\begin{array}{l}\text { Alkalinity } \\
\text { (corrected) }\end{array}$ & $\begin{array}{l}\text { New } \\
\text { Date }\end{array}$ & pH & $\begin{array}{l}\text { ( } \mu \in q / \ell \text { ) } \\
\text { Alkalinity }\end{array}$ & $\begin{array}{l}\text { Specific } \\
\text { ( Sienens) } \\
\text { Conductance }\end{array}$ & $\begin{array}{c}(\mu \in q / \ell) \\
\text { Calcium }\end{array}$ & $\begin{array}{l}\text { Estimated } \\
\text { old Alk. } \\
\text { from } \mathrm{Ca}\end{array}$ & \\
\hline $\begin{array}{l}\text { Still Brook } \\
\text { Stinson Lake, }\end{array}$ & $7 / 19 / 38$ & 7.0 & & & $8 / 2 / 79$ & 6.5 & 111 & 25 & 101 & 111 & 0 \\
\hline $\begin{array}{l}\text { Grafton Co. } \\
\text { Elsworth Outlet, }\end{array}$ & $8 / 6 / 38$ & 6.8 & 70 & 30 & $8 / 2 / 79$ & 6.2 & 33 & 20 & 88 & 93 & -60 \\
\hline $\begin{array}{l}\text { Grafton Co. } \\
\text { Drakes Brook, }\end{array}$ & $8 / 10 / 38$ & 6.8 & 100 & 60 & $8 / 2 / 38$ & 6.1 & 57 & 19 & 106 & 119 & -62 \\
\hline $\begin{array}{l}\text { Grafton Co. } \\
\text { osceola Brook, }\end{array}$ & $7 / 21 / 39$ & 6.8 & & & $8 / 2 / 79$ & 6.2 & 46 & 24 & 103 & 114 & -68 \\
\hline $\begin{array}{l}\text { Grafton Co. } \\
\text { Eastman Brook, }\end{array}$ & $7 / 24 / 39$ & 6.8 & & & $8 / 2 / 79$ & 6.3 & 74 & 38 & 117 & 134 & -60 \\
\hline $\begin{array}{l}\text { Grafton Co. } \\
\text { Little East Pond Brook, }\end{array}$ & $7 / 24 / 38$ & 7.0 & & & $8 / 2 / 79$ & 6.6 & 90 & 25 & 103 & 114 & -24 \\
\hline $\begin{array}{l}\text { Grafton co. } \\
\text { Russell Pond, }\end{array}$ & $7 / 24 / 38$ & 7.0 & & & $8 / 2 / 79$ & 6.6 & 90 & 25 & 89 & 94 & -4 \\
\hline Grafton Co. & $7 / 24 / 38$ & 6.6 & 90 & 50 & $8 / 2 / 79$ & 6.1 & 49 & 20 & 101 & 111 & -62 \\
\hline
\end{tabular}




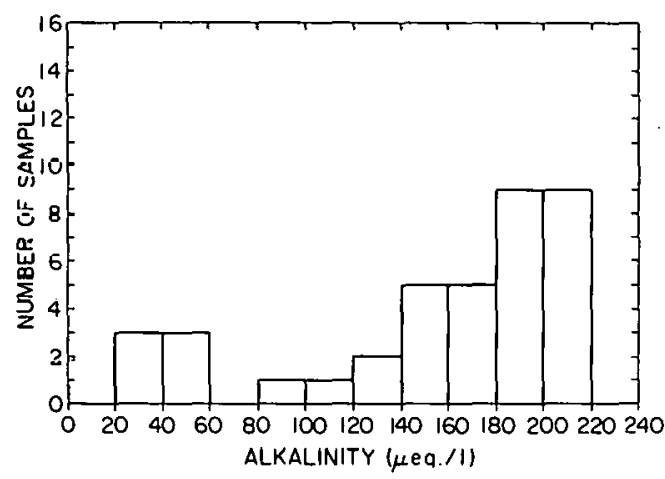

Figure IV-1. North Carolina Fisheries Data (June, July or August 1960-1963)

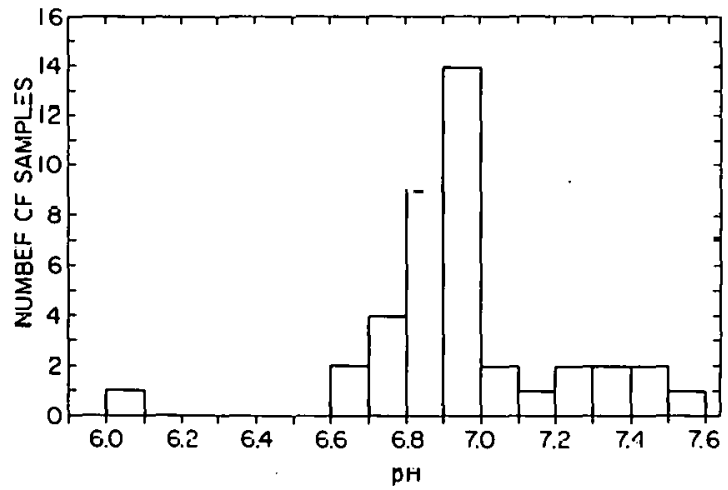

Figure IV-3. North Carolina Fisheries Data (June, July or August 1960-1963)

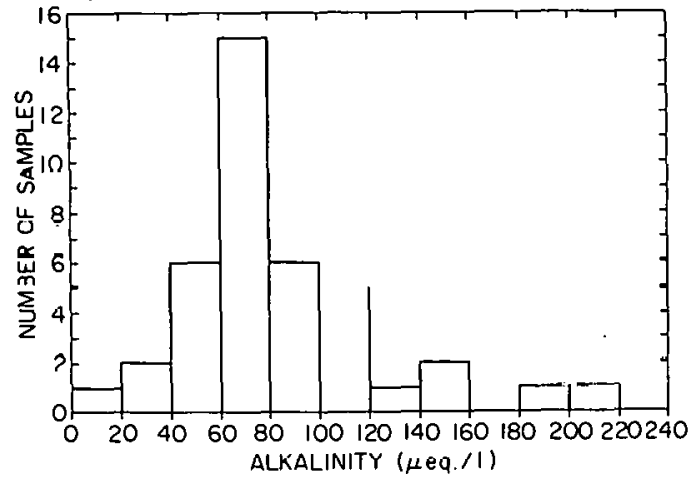

Figure IV-2. North Carolina Field Trip $(6-29-79-7-4-79)$

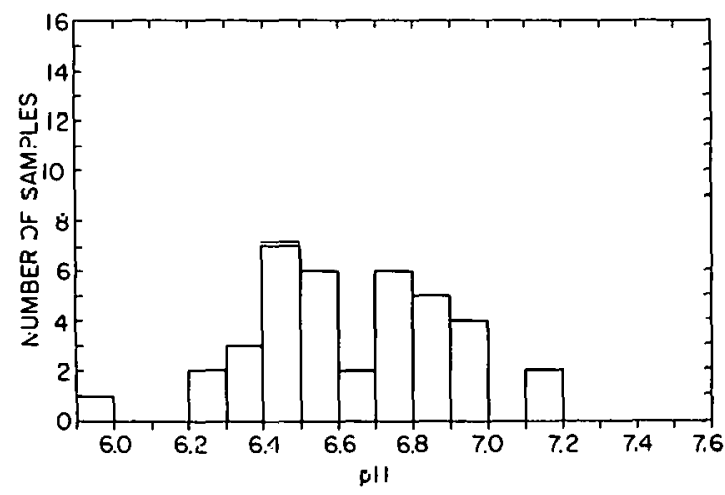

Figure IV-4. North Carolina Field Trip $(6-29-79-7-4-79)$ 


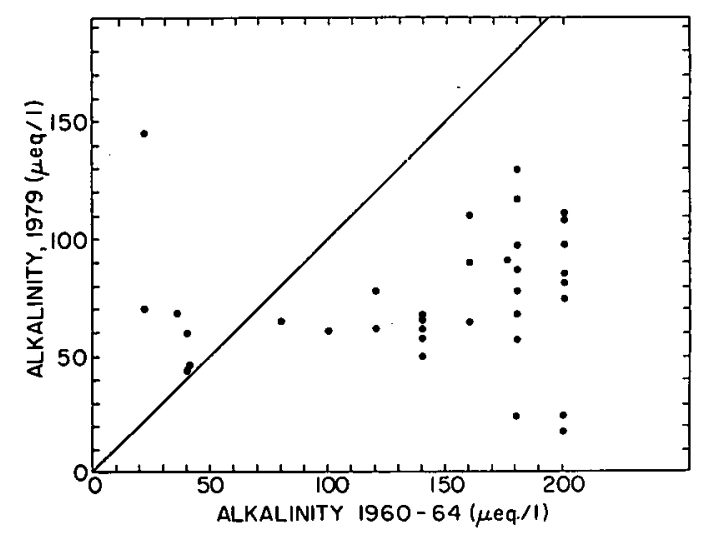

Figure IV-5. Alkalinity vs. Alkalinity for North Carolina Streams

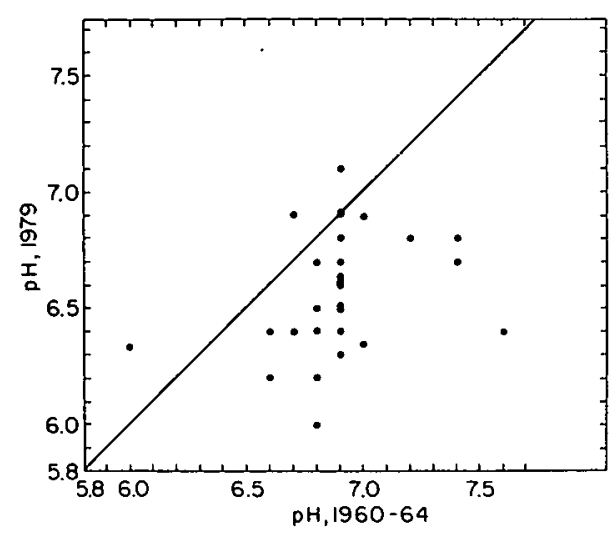

Figure IV-6. $\mathrm{pH}$ vs. $\mathrm{pH}$ for North Carolina Streams

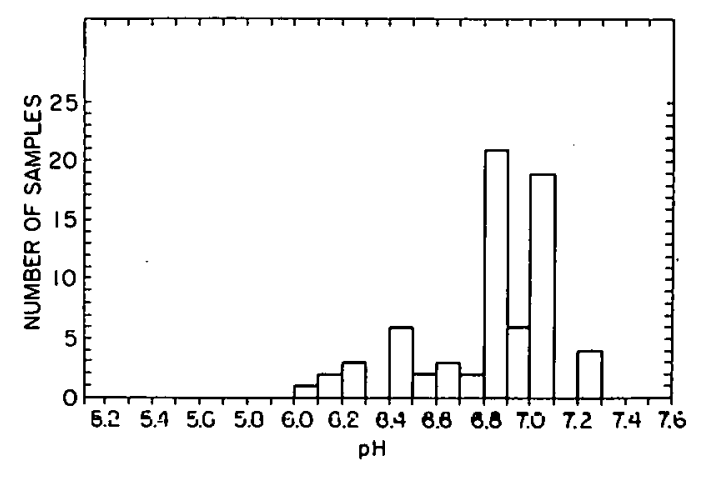

Figure IV-7. New Hampshire Fisheries Data (Summers of $1937,1938,1939$ ) 


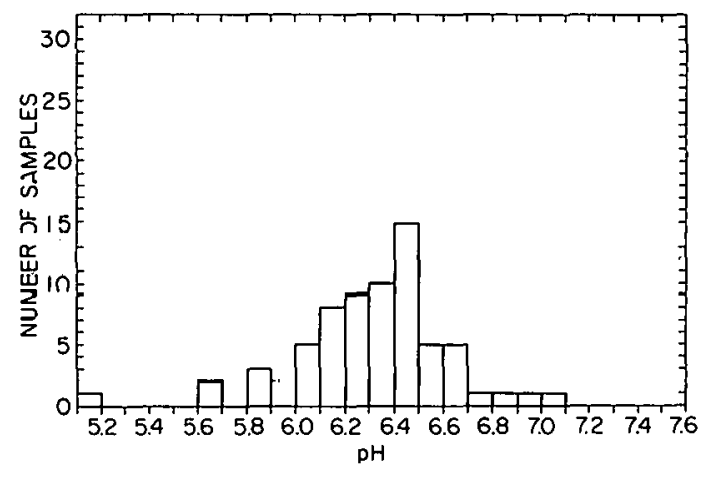

Figure IV-8. New Hampshire Field Trip $(7-26-79-8-2-79)$

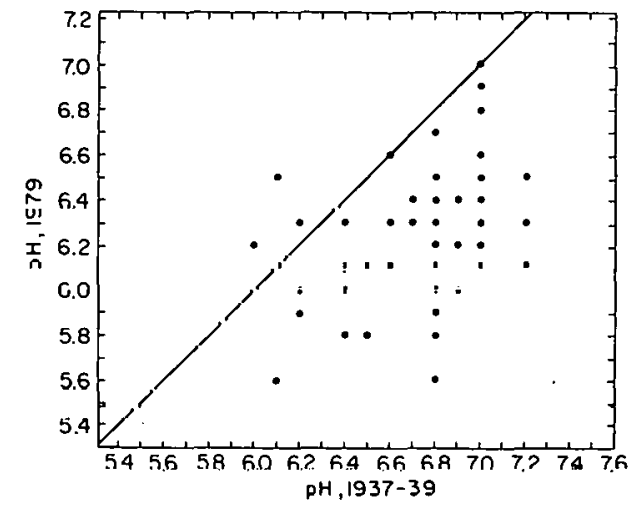

Figure IV-9. pH vs. pH for New llampshire Streams \& Lakes

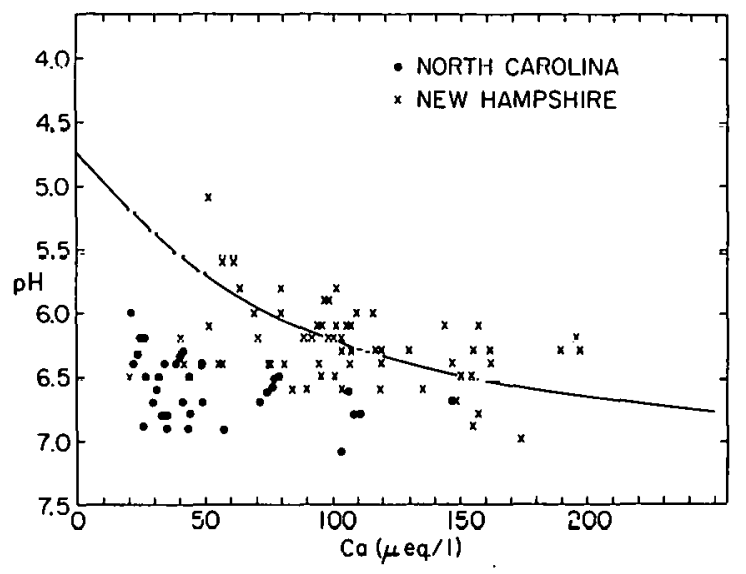

Figure IV-10. Calcium vs. pH for Headwater Streams in N.C. \& N.H. 


\section{IMPACTS OF ACIDIFICATION ON AQUATIC BIOTA}

Acidification of surface waters in sensitive areas causes a variety of changes in the aquatic flora and fauna. The extent of this impact ranges from changing population strengths to complete elimination of many species. The purpose of this section is to provide a review and description of the kinds of biological impacts which have been observed and which may be anticipated in sensitive waters which are altered by acid precipitation. Impacts on organisms other than fish are stressed here. Impacts on fish are discussed in section VI. This section is a collation of materials previously presented, and includes references to affects of acid mine drainage on biota.

Although the literature concerning effects of acid mine drainage (AMD) on freshwater ecosystems is extensive, it is not directly applicable to the acid precipitation problem. Often the uncontaminated waters of coal mining areas have higher alkalinity and hardness than the very soft waters acidified by acid precipitation. AMD water usually has a heavy load of iron and other heavy metals, and frequently depresses the oxygen concentration of receiving waters. High turbidity and the presence of chemical floc are also common and greatly alter aquatic habitats. These factors make it very difficult to extrapolate observations from AMD situations to those in the Laurentian Shield, for example.

The variety of species of both plants and invertebrate animals occurring in fresh waters is enormous and speciation differs markedly from one locale to another even though water chemistry may be similar. It is at best difficult and probably futile to try to interpret ecosystem damages at lower trophic levels by comparing lists of species. On the other hand, changes in major processes such as primary and secondary production, and decomposition can be broadly described and compared. Effects of stress on the major functional guilds may be compared from place to place. Finally a few groups of organisms seem to be remarkably insensitive to strong mineral acidity and are common to many acid environments, while some other groups are clearly intolerant of $\mathrm{pH}$ levels below 6.0 to 5.5 .

\section{A. Effects on Microbiota}

The production of $\mathrm{fish}$ and other animal life in a lake is ultimately dependent upon the availability of organic food resources, primarily plant materials. The sources of organic materials may be divided into two major categories: autochthonous, originating by primary production in the lake, and allochthonous, transported into the lake by inflowing water, airborne litter, or dissolved in rain. The relative importance of each of these sources varies greatly from lake to lake. One principal route for both authochthonous and allochthonous organic matter into the trophic system of a lake is via the detritus.

Bacterial consumption and mineralization of detrital organic matter, both particulate (POM) and dissolved (DOM), allows a cycling of carbon which dominates the structure and the functioning of the system and provides what Wetzel ${ }^{98}$ has called a fundamental stability to the system. In the deep, open 
water of the pelagic zone, where phytoplankton production normally provides a substantial portion of the nonrefractory organic matter, bacteria rapidly assimilate dissolved labile organic substances (PDOM) derived from photosynthesis 29,46 and convert it into bacterial biomass. Particulate organic matter (РОM) from phytoplankton is assimilated at a somewhat slower rate. Only a small portion of the PDOM is refractory material likely to survive longer than $24 \mathrm{hr} .88$ The bacterial mineralization rate appears to be rather slow, a few percent per day17,99, so that this new biomass is actually available to other trophic levels. Not only do the bacteria conserve the energy stored in labile PDOM, which otherwise would be lost from the system, but they also convert (at a slower rate) some of the refractory DoM into a usable form. Fungal and bacterial communities render other POC into forms which are useful for detritovores.13 The significance of these activities to ecosystem energetics can be better appreciated when one considers that on the order of $90 \%$ of the organic carbon in the water column is DOM and that detr1tal POM is many times larger than the total living carbon biomass.

There are other sources of detritus in the pelagic zone. In some lakes, particularly smaller and/or shallow lakes, macrophytes and benthic algae are Important sources of autochthonous organic carbon. Material from these plants may contribute significantly to detritus in the pelagic zone. In deciduous forcst lakes, leaf litter falling or blown onto the surface annually has been found to be 200 to $500 \mathrm{~g}$ dry leaves per meter of wooded shore line.35,60 This forest litter, plus that which is added by stream imputs, contributes to both DOM (after leaching) and POM.

Water column detritus generated from all of these sources has three possible fates. It can be transformed biologically, it can sink to the sediments where it accumulates and/or is transformed biologically, or it is lost from the system by outflow. In the first two cases, microbial activity plays a key role in removing detritus.

The inhibition of microbial decomposition can have profound effects throughout an aquatic ecosystem. Detritus removal, conservation of energy, nutrient recycling, primary production, detritivore production and thus production at higher trophic levels, can all be affected by changes in microbial activity. Several investigations have indicated that microbial decomposition is greatly inhibited in waters affected by acid precipitation.

An abnormal accumulation of coarse organic detritus has been observed on the bottoms of six Swedish lakes where the $\mathrm{pH}$ decreased by 1.4 to 1.7 units in the past three to four decades. ${ }^{37}$ Bacterial activity apparently decreased, while in some of the lakes the sediment surfaces over large areas were made up of dense felts of fungal hyphae. In one of the lakes, Gardsjön, $85 \%$ of the bottom in the $U$ to $2 \mathrm{~m}$ depth zone was covered with a thick felt of algae and organic debris, plus fungal hyphae. Lime treatment caused a rapid decomposition of the organic litter as well as great reductions of the felt ${ }^{4}$, indicating that an inhibition of bacterial activities had taken place at low $\mathrm{pH}$. Similar neutralizations of acidified lakes in Canada resulted in a significant increase in aerobic heterotrophic bacteria in the water column. 89 Results from field and laboratory experiments with litterbags in Norway 49 also indicate reduced weight loss of leaves in acidic waters. Dissolved organic carbon (DOC) in the inflowing water was found to contribute ca. $50 \%$ of allochthonous inputs and $8 \%$ of all organic carbon in Mirror Lake, while fine 
particulate organic carbon (FPOC) was negligible.60 The extent to which this DOC input is converted to bacterial biomass or otherwise enters into the energetics of a lake is not known. Observations of abnormal accumulations of organic debris have also been made in AMD waters in South Africa 44 and West Virginia ( $\mathrm{J}$. DeCosta pers. comm.).

In laboratory experiments the decomposition rate of peptone by microbiota decreased with $\mathrm{pH}$ and the oxidation of ammonia ceased below $\mathrm{pH} 5$. Bacterial cell counts and the species number of ciliates also decreased. 12 Numerous other studies indicate that the microbial decomposition of organic materials is markedly reduced at $\mathrm{pH}$ levels commonly encountered in lakes affected by acid precipitation. 49

Accumulations of organic debris and extensive mats of fungal hyphae, as observed in the Swedish Lakes 37 , both seal of $f$ the mineral sediments from interactions with the overlying water and retain organically bound nutrients which would otherwise have become available if normal decomposition had occurred. The reduction in nutrient availability can be expected to have a negative feedback effect on both plants and bacteria, further inhibiting their activities. The reduction of nutrient supplies to the water column from the sediments, because of the physical covering and from reduced mineralization of organic materials in the water itself, will lead to reduced phytoplankton productivity. These ideas have been formulated into the hypothesis of "selfaccelerating oligotrophication" by Grahn et al.37 Qualitative observations support this hypothesis but a quantitative evaluation is lacking.

Reduction of microdecomposer activities may have a direct effect upon the invertebrates. Although certain benthic invertebrates appear to feed directly on the allochthonous detritus material, it seems that "conditioned" (colonized by microorganisms) material is preferred, and that the nutritional value of the detritus is highly increased by conditioning. 13 Bacteria may also be a food source to be removed by the filtering apparatus of organisms such as Calanoida. An inhibition of the microbiota or a reduction in microbial decomposition processes would therefore have a direct impact on the lakes' animal communities.

\section{B. Effects on Benthic Plants}

In waters affected by acid precipitation major changes occur within plant communities. Most of the available data are qualitative and descriptive although some experimentation has been done. Intact lake sediment cores which included the rooted macrophyte Lobelia dortmana were incubated at three $\mathrm{pH}$ levels $(4.0,4.3$ to $5.5,6.0)$ at Tovdal in southern Norway. The growth and productivity of the plant $\left(\mathrm{O}_{2}\right.$ production) were reduced by $75 \%$ at $\mathrm{pH} 4$ compared to the control ( $\mathrm{pH} 4.3$ to 5.5 ) and the period of flowering was delayed ten days at the low $\mathrm{pH} .66$

In five lakes of the Swedish west coast, a region severely affected by acid precipitation, in the past three to five decades the macrophyte communities dominated by Sphagnum have expanded. In the sheltered and shaded locality of Lake Orvattnet, in the 0 to $2 \mathrm{~m}$ depth zone, the bottom area covered by Sphagnum increased from 8 to $63 \%$ between 1967 and 1974 . In the 4 to $6 \mathrm{~m}$ depth 
zone, the increase was from 4 to $30 \%$. At the same time, pH in Orvattnet decreased 0.8 units to ca. 4.8.38 Similar growths of Sphagnum occur in other Swedish lakes, in Norweglan lakes, and in AMD water as we11.42,44,45,49 At the $\mathrm{pH}$ of these acid waters, essentially all of the avallable 1norganic carbon is in the form of $\mathrm{CO}_{2}$ or $\mathrm{H}_{2} \mathrm{CO}_{3}$. Conditions are more favorable for Sphagnum, an acidophile which appears to simply outgrow the flowering plants under acid conditions.

In developing their hypothesis on oligothrophication, Grahn et al.37 have stressed two biologically important consequences of this Sphagnum expansion. First, Sphagnum has an ion-exchange capacity which results in the withdrawal of base ions such as $\mathrm{Ca}$ from solution, thus reducing their availability to other organisms. Second1y, dense growths of Sphagnum form a distinct biotope which is unsuitable for many members of the bottom fauna.

Under some acid conditions, unusual accumulations of both eplphytic and epilythic algae may occur. In the Swedish lakes Mougeotia and Batrachospermum become important components of the benthos. 37 In Lake Oggevatn (pH 4.6), a clear-water lake in southern Norway, not only is Sphagnum beginning to choke out Lobelia dortmana and Isoetes lacustris, but these macrophytes have been observed to be festooned with filamentous algae. 49

A floristic survey, conducted in Lake Colden (elevation 842m) in 1932, does not mention Sphagnum, but describes a macrophyte community typical of clear oligotrophic lakes of the Adirondack Mountalns (Eriocaulon, Lobella, Myriophyllum, Isoetes, Utricularia, etc.). On 6/11/58 Colden's surface pH was 5.8 In mid-July 1979, $\mathrm{pH}$ was 4.9 and the flora from the shore to $0.5 \mathrm{~m}$ depth (ca. 2-5m from shore) around most of the lake perimeter was dominated by extremely dense, uniform stands of Sphagnum pylaesii Brid. (390 $\left.\mathrm{g} \mathrm{m}^{-2}\right)$. In some areas Utricularia alone or with Sphagnum also formed dense stands which were covered over by flocculent growths of algae in which Fragilaria viresence, Tabellaria fenestrata, Eunotia triodon and Mougeotia sp. were abundant. Prominent mats composed primarily of biué-green algae, fungal hyphat all plithl detritus were spreading over the dense Utricularia stands (G. H. Hendrey and F. Vertucci, unpublished data). Colden, once famous for its trout fishing, is now too acidic to support fishlife. These observations, the first of their kind in North America, parallel findings in some acidified Swedish and Norwegian lakes. The question of why some acidified lakes show these extreme floristic changes, while many others do not, remains a mystery.

Heavy growths of filamentous algae and mosses occur not only in acidified lakes but have also been reported in streams in Norway affected by ac1dification. In experiments in artificial stream channels using water and the naturally seeded algae from an acidified brook ( $p h 4.3$ to 5.5 ), an increase in the acidity to $\mathrm{pH} 4$ by addition of sulfuric acid led to an increased accumulacion of algae compared to an unmodified control.48 The flora was dominated by Binuclearia tatrana, Mougeotia spp., Eunotia lunaris, Tabellaria flocculosa, and Dinobyron spp., each accounting for at least $20 \%$ of the flora at one time or another. The rate of radioactive carbon uptake per unit of chlorophyll in the channels, measured on just two occusiuns, was found to be lower in the acid channel by ca. $30 \%$, suggesting greater algal accumulation at low $\mathrm{pH}$ despite lower productivity. 
Several factors may contribute to these unusual accumulations of certain algae. The intolerance of various species to low $\mathrm{pH}$ or to consequent chemical changes ${ }^{76}$ will allow just a few algal species to utilize the nutrients available in these predominantly oligotrophic waters. Many species of invertebrates are absent at low $\mathrm{pH}$, and removal of algae by grazing is probably diminished. Microbial decomposition is inhibited, as was previously noted, also reducing the removal of algal mass.

\section{Effects on Phytoplankton}

There is no consistency among various investigations as to which taxa are likely to be dominant under conditions of acidification. The Pyrrophyta may be more common (e.g., species of Peridinium and Gymnodinium) than others in lakes near 4.0 . With decreasing $\mathrm{pH}$ in the range 6.0 to 4.0 , many species of the Chlorophyta are eliminated although a few tolerant forms are found in the acid range. In the survey of 155 Swedish west coast lakes, blue green algae became less important with decreasing $\mathrm{pH}, 1$ but Kwiatkowski and Roff 65 found the opposite to be true in lakes of the Sudbury, Ontario, region.

There are, however, conspicuous decreases in phytoplankton species number, species diversity, biomass, and production per unit volume ( $\left.\mathrm{mg} / \mathrm{m}^{3}\right)$ with decreasing $\mathrm{pH}$. Lake clarity and the compensation depth increase with lake acidification, so that areal primary production $\left(\mathrm{mg} / \mathrm{m}^{2}\right)$, although lower in acid than nonacid lakes, is not as severely depressed as is production per unit volume. $1,58,65$ The low phytoplankton biomass $(<1 \mathrm{mg} / \ell)$ has been correlated to the concentration of available phosphorus, which generally decreases with lower lake pH. 1 Low availability of inorganic carbon has also been suggested as a factor limiting primary production in acidic lakes. 58,63

Kwiatkowski and Roff 65 have carried out a highly quantitative study of phytoplankton in six lakes of the Sudbury region, which are impacted by atmospheric effluents from a huge nickel-copper smelter complex. Curvilinear equations are presented for phytoplankton diversity, secchi transparency depth, Ch1. a, and productivity.

\section{Effects on Invertebrates}

Zooplankton analyzed from net samples collected from 84 lakes in Sweden showed that acidification caused the elimination of many species and led to simplification of zooplankton communities. 1 Crustacean zooplankton were sampled in 57 lakes during a Norwegian lake survey in 1974, 47 and the number of species observed was found to decrease with pH. The distributions and associations of crustacean zooplankton in 47 lakes of a region of Ontario affected by acid precipitation were strongly related to $\mathrm{pH}$ and to the number of $f$ ish species present in the lakes. However, $f$ ish and zooplankton were each correlated with the same limnological variables, especially $\mathrm{pH}^{94}$ Zooplankton communities become less complex with fewer species present as acidity increases. Food supply, feeding habits, and grazing of zooplankton will probably be altered following acidification, as a consequence of decreased biomass 
and species composition of planktonic algae and bacteria. In streams continuously polluted by AMD, the number of zooplankton species was low compared to the number of individuals, was lower than in less polluted conditions downstream. 84

Surveys at many sites recelving acid precipitation in Norway, Sweden, and North American $4,14,18,47$ have shown that waters affected by acid precipitation have fewer species of benthic invertebrates than localities which are less acid. In 832 Norwegian lakes, J. $\not k l$ and 81 found no snails at $\mathrm{pH}$ values below 5.2; snails were rare in the $\mathrm{pH}$ range 5.2 to 5.8 and occurred less frequently in the $\mathrm{pH}$ range 5.8 to 6.6 than in more neutral or alkaline waters. The amphipod Gammarus lacustris, an important element in the diet of trout in Norweglan lakes where it occurs, is not found in lakes with $\mathrm{pH}$ less than 6.0.82 Experimental investigations have shown that the adults of this species cannot tolerate 24 to 48 hours of exposure to $\mathrm{pH} 5.0 .15$

In the River Duddon in England, $\mathrm{pH}$ is the overriding factor which prevents permanent colonization by a number of species of benthic invertebrates, primarily herbivores, of the upper acidified reaches of the river. 95 In the more acid tributaries $(\mathrm{pH}<5.7)$, the fauna consisted of an impoverished Plecopteran community. Ephemeroptera, Trichoptera, Ancylus (Gastropoda), and Gammarus (Amphipoda) were absent. The epiphytic algal flora was reduced (in contrast to increases noted in Norway), and leaf litter decomposition was retarded. The food supply of the herbivores was apparently decreased, and this may have played a role in the simplification of the benthic fauna. Quantitative data concerning the effects of low $\mathrm{pH}$ on the benthic fauna are also available for some acid Norwegian lakes, 49 where notably low standing crops have been observed.

Many studies of invertebrate communities in streams receiving AMD have been conducted. Comparisons are usually made between affected and unaffected zones or tributaries, and experimental acidification has been performed. 54 The numbers of species, species diversity, and biomass are usually greatly reduced. Generally, in AMU waters Chironomidae (midges) and Sialis (alderfly) are the most tolerant macroinvertebrates. The order Trichoptera has more tolerant species than does Plectoptera (stone flies), and Plecoptera has more tolerant species than does Ephemeroptera (mayf 1 ies). $25,26,44,45,84,102$

This order of tolerance is essentially the same as seen in waters acidified by acid precipitation. However, the Hemiptera, Notonectidae (backswimmer), Corixidae (water boatman), and Gerridae (waterstrider) are of ten abundant in aciditied sott waters at pli as low as 4.0. Th1s máy, in part, be due to lack of fish predation.

Benthic plant communities in lakes may be greatly altered as a consequence of lake or stream acidification (as discussed above). Under these conditions, benthic invertebrate populations may be affected by starvation, evacuation, or extinction due to the loss of preferred habitat. Chironomids 83 and other benthic invertebrates, 20 present in many of the poorly buffered northeastern lakes, have diverse feeding habits and habitats. These invertebrates, in many situations, will be affected by altered decomposition cycles and variations in available foods caused by increased acidification. 
The tolerance of aquatic invertebrates to low $\mathrm{pH}$ varies over their life cycles, and the emergence of adult insects seems to be a period particularly sensitive to low pH levels. Bellil and Moss,76 in similar studies with Trichoptera and Ephemeroptera, found emergence patterns to be affected at $\mathrm{pH}$ levels which were higher than the 30-day survival limits. Many species of aquatic insects emerge early in the spring, even through cracks in the ice and snow cover. Because of the contamination of spring meltwaters by atmospheric pollutants, including heavy metals, $41,50,55,56$ the early emergers must, in many cases, be exposed to the least desirable water conditions.

Damage to invertebrate communities will influence other components of the food chains. Benthic invertebrates assist with the essential function of removing dead organic material. In litterbag experiments, the effects of invertebrates on leaf decomposition were much more evident at higher $\mathrm{pH}$ than at low $\mathrm{pH} .49$ A reduction of grazing by benthic invertebrates may also contribute to the accumulation of attached algae in acidified lakes and streams.

A short reach of Norris Brook, a tributary to Hubbard Brook in New Hampshire, was acidified to $\mathrm{pH} 4$ in the Spring-Summer of 1977, to evaluate the effects of acidification on a stream ecosystem. Excessive accumulations of algae occurred, bacterial biomass and heterotrophic activity per unit of organic matter were reduced, and both invertebrate diversity and biomass decreased. 43

In unstressed lake ecosystems there tends to be a continuous emergence of different insect species available to predators from spring to autumn. In acid-stressed ecosystems the variety of prey is reduced and periods may be expected to occur in which the amount of prey available to fish (and waterfowl) is diminished.

\section{E. Effects on Vertebrates}

Pough 86 has described effects of acid precipitation on spotted salamanders (Ambystoma jeffersonianum and $A$. maculatum), which breed in temporary rain pools. Below $\mathrm{pH} 5$ and 7 , respectively, these species suffered high mortality during hatching in laboratory tests. This mortality was associated with distinctive embryonic malformations. The development of salamander eggs in five puinds uedr Ithaca, NY, ranging from $\mathrm{pH} 4.5$ to 7.0 , were observed. An abrupt transition from low to high mortality occurred below $\mathrm{pH} 6$. Although a synergistic effect of several stresses may have been possible, the studies suggested that $\mathrm{pH}$ was the critical variable. Pough cites studies which indicate a decline in British frog populations. 86

In Tranevatten, a lake acidified by acid precipitation, near Gothenburg, Sweden, the lake $\mathrm{pH}$ has declined to 4.0 to 4.5 , and all $\mathrm{fish}$ have been eliminated. The frog species Rana temporaria is being eliminated as well. Currently, only adults 8 to 10 years old are found. While many egg masses were observed in 1974, few were found in 1977. The few larvae observed in 1977 subsequently died. Another species, Bufo bufo, is also being eliminated from this lake. 42 
Frogs and salamanders are important predators on invertebrates, including mosquitoes and other pests, in lakes and puddles or pools. In turn, they are themselves important prey for higher trophic levels in an ecosystem.

\section{F. Biological Effects Summary}

Acid precipitation, by causing increased acidity in lakes, streams, pools, and puddles, can cause slight-to-sevcre alteration in communities of aquatic organisms. The effects are similar to those observed in waters receiving acid mine drainage (AMD), but the toxicology and chemistry are not as complicated by the presence of high concentrations of heavy metals, chemical flocs, turbidity, etc., such as are found in AMD.

The kinds of effects that are likely to result from increasing acidificaLLun aie sliuwn in Tablc V-1. In order to provide step-tunctions tor danages, which may be of use in modelluy ecusysteü acidification, a cummary of damages to aquatic organisms as functions of $\mathrm{pH}$ is presented in Table $\mathrm{V}-2$. 
Table V-1

Damages to Aquatic Biota Likely to Occur with Increasing Acidity

1. Bacterial decomposition is reduced and fungi dominate saprotrophic communties. Organic debris accumulates rapidiy.

2. The cillate fauna is greatly inhibited.

3. Nutrient salts are taken up by plants tolerant of low $\mathrm{pH}$ (mosses, f1lamentous algae) and by fungi. Thick mats of these materials may develop which inhibit sediment-to-water nutrient exchange and choke out other aquatic plants.

4. Phytoplankton specles diversity, biomass, and production are reduced.

5. Zooplankton and benthic invertebrate species diversity and biomass are reduced. Remaining benthic fauna consists of tubificids and Chironomus (midge) larvae in the sediments. Some tolerant specles of stone flies and mayflies persist as does the alderfly. Alr-breathing bugs (waterboatman, backswimmer, water strider) may become abundant.

6. Fish populations are reduced or eliminated (see Section VI).

Table V-2

Summary of Damages to Aquatic Organisms with Decreasing pH

$\mathrm{pH}$ range Effects

8.0-6.0 Long-term changes of less than $0.5 \mathrm{pH}$ units likely to alter the blotic composition of freshwaters to some degree. The significance of these slight changes is however, not great.

A decrease of 0.5 to $1.0 \mathrm{pH}$ units in the range 8.0 to 6.0 may cause detectable alterations in community compositon. Productivity of competing organisms will vary. Some species will be eliminated.

6.0-5.5 Decreasing pH will cause a reduction in species numbers and, among remaining spectes, significant alterations in ablitty to withstand stress.

5.5-5.0 Many species will be eliminated, and species numbers and diversity indices will be reduced. Crustacian zooplankton, phytoplankton, molluscs, amphipods, most mayfly species, and some stone fly specles will begin to drop out. In contrast, several pH-tolerant invertebrates w11l become abundant, especially the air-breathing forms (e.g., Gyrinidae, Notonectidae, Corixidae), those wlth tough cuticles which prevent ion losses (i.e. S1alis lutaria), and some forms which live within the sediments (01igochaeta, Chiromomidae, and Tublficidae). Overall, invertebrate blomass will be greatly reduced.

5.0-4.5 Decomposition of organic detritus will be severely impaired. Autochthonous and allochthonous debris will accumulate rapidly. Most fish spectes are eliminated.

< 4.5 All of the abovc changes will be greatly exacerbated, and all fish w111 be eliminated. 


\section{REGIONAL ASSESSMENT OF ACIDIFICATION IMPACTS OF FISH POPULATION}

\section{A. Introduction}

Acidification of surface waters in geologically sensitive regions by acid precipitation may be viewed as a continuous process of water quality change, analogous to the acidimetric titration of a bicarbonate solution. The "titration curve" can be segmented into three stages, which define both the extent and nature of water quality change and the biological impacts. The initial stage of acidification is characterized by decreased alkalinity, but $\mathrm{pH}$ levels remain greater than 6.0 and bicarbonate buffering is maintained. No significant impacts on fish population have been observed at this level of acidification. Loss of $\mathrm{HCO}_{3}$ buffering, and resulting severe temporal $\mathrm{pH}$ fluctuations occur in the second stage of deldification. Etrcoo, reproductive inhihitinn, and episodic mortalities may initiate recruitment fallure and eveulud. extinc tion of fish populations during this stage of acidification. The final stage of acidiflcation is characterized by chronically depressed $\mathrm{pH}$ and elevated toxic metal levels. Fish are generally absent from waters at this level of acidification. This general view of acidification impact levels on fish populations is supported by extensive, carefully documented data from sensitive regions in Norway 103 and eastern North America.9,91

More recently, Henriksen 52,53 has developed models of the acidification process which quantitatively relate the stages of acidification described above to precipitation acidity levels in sensitive regions. These models provide a basis for predicting the regional extent and levels of acidification which have occurred in sensitive areas where historical data are lacking. The models also permit evaluation of expected fish population status on a regional level. Considering the paucity of carefully documented fish population data for waters in sensitive areas of the eastern United States and the time constraints for obtaining and interpreting new data, it was declded to utilize the predictive modela to obtain a regional perspectlve of acidification impacts on fish populations. The approach taken was to first calibrate the Norwegian models using North American data and verify the predictions obtained by comparison with known water quality and fish population data from the Adirondack region (New York) and Experimental Lakes Area (Ontario, Canada). The next step will be to apply the models to water quality data from other sensitive regions in the United States to evaluate ac1dification and fish population status.

B. Propedure.

Data Sources. Wacer yualily and tish populaclun dala bititaned from the following sources were utilized in model calculation and testing.

1 Water chemistry and fish survey data for Adirondack Mountain lakes (New York): Schofield (1976 and file data); New York State Biological Surveys of the Upper lludoon, Raquette, MnhawkHudson, and Black River Watersheds (1931-1934, NYS Dept. Conservation). 
2 Stream water quality and fish population status in selected areas of West Virginia: Personal Communication and file data from Donald Gasper, W. Virginia Dept. of Natural Resources.

3 Water quality data for lakes in the BWCA, N.E. Minnesota: G.E. Glass, EPA Research Lab (Duluth), Draft report on Impacts of air pollutants on Wilderness areas of $\mathrm{N}$. Minnesota.

4 Water chemistry and fish population data for Connecticut lakes. 24,79

5 Water chemistry and flsh population data for Rhode Island lakes. 39,40

6 Water chemistry for Massachusetts lakes. 21

7 Water chemistry and fish population data for ELA lakes. 9

8 Water chemistry and fish population data for the North Carolina bay lakes. 30,31

9 Water chemistry for coastal plain streams in S. Carolina and Genrgia.10

\section{Model Calibration and Verification}

1. Acidification. Acidification is defined as the decrease in alkalinity, which results from an equivalent increase in strong acid input. Three independent approaches to estimating reglonal acidification were applied to the Adirondack lake data base. The first approach developed by Henriksen 51 utilized the empirical relationships between precipitation $\mathrm{pH}$ (volume weighted annual mean) and estimated regional acidification of lakes in southern Norway. Regional acidification, a decrease in alkalinity associated with excess sulfate (corrected for seasalt) in precipitation (Ac-S, $\mu$ eq/ $\ell$ ), was calculated by regression as:

$$
\mathrm{Ac}-\mathrm{S}=\frac{\left(10^{-\mathrm{pH}} \times 10^{6}\right)-17}{0.38}
$$

The volume weighted, mean annual hydrogen ton concentration for precipitation collected in the western Adirondack region (Hinckley, New York; USGS network) in 1975 was $\mathrm{pH}$ 4.26. Substituting this value in equation (1) yields an estimated acidification level of $99.9 \mathrm{eq} /$ as the average regional acidification of the western Adirondacks.

The second approach to estimating actdification was also as given by Henriksen 51: Acidification = pre-acidification alkalinity - present day alkalinity. In this case, pre-acidification alkalinities (ALKp) for the Adirondack lakes were estimated from 1975 measurements of calcium concentrations and the empirical relationship between calcium concentration and alkalinity observed in the Experimental Lakes Area (Ontario) waters: 


$$
\operatorname{ALKp}(\mu \mathrm{eg} / 1)=1.42(\mathrm{Ca} \mu \mathrm{eq} / 1)-32
$$

The assumptions made in employing this method of estimating pre-acidification alkalinities are as follows:

a) Alkalinity in pristine (unacidified) lakes (e.g. the ELA region) is due primarily to $\mathrm{HCO}_{3}{ }^{-}$, which is accompanied by approximately equivalent amounts of calcium and magnesium, and the $\mathrm{Ca} / \mathrm{Mg}$ ratio is relatively constant. This relationship (equation 2) is of a general nature and can be applied to other regions with similar geological settings. This assumption is supported by the similarity of the calcium-alkalinity relationship for pristine lakes in northern Norway and the ELA. 52

h) Ca1rium levels do not increase or decrease in response to acldificac1on. H1storleal calisiul data are not availablc for the Adirondasks region, but estimates of calcium from 1930's alkiliulty date and equation (2) were not significantly different $(P=.05)$ from calcium levels measured III $197 \mathrm{~J}$ fui 36 Adirondack lakco. Additional support for this assumption comes from studies in Sweden ${ }^{73}$ which demonstrated that no significant changes in calcium concentration were detected in acidified lakes of south-central Sweden, where signiticant increases in $\mathrm{H}^{+}$and $\mathrm{SO}_{4}^{-2}$ did occur. Also, Wiklander 100 reported that base exchange efficiency is very low in acidic podzols, where the exchange complex is typically dominated by $\mathrm{H}^{+}$and $\mathrm{Al}^{+3}$ ions, rather than $\mathrm{Ca}^{+2}$. Watt (1979) compared the $\mathrm{pH}$ and ionic composition of lakes in Nova Scotfa sampled in 1955 and 1977. Significant decreased in $\mathrm{pH}$ levels were observed but no significant change in $\mathrm{Ca}^{++}$was found. 96

Acidification (Ac-Ca) was then calculated as Llé difference betwecn preacidification alkalinity (equation 2 ) and current alkalinity measurements $\left(\mathrm{ALK}^{\star}\right)$ :

$$
\mathrm{Ac}-\mathrm{Ca} \mu \mathrm{eq} / \ell=\mathrm{ALKp}-\mathrm{ALK}^{*}
$$

The estimated mean acidification for 215 Adirondack lakes sampled in 1975 was $\mathrm{Ac}-\mathrm{Ca}=99.6 \mathrm{\mu eq} / \ell\left(S \cdot \mathrm{D}_{0}=30.6\right)$, whlch compares well with the first estimate of acidification $(A c-S=99.9 \mu \mathrm{eq} / \ell)$. These estimates of lake acidification are not correlated with current $\mathrm{pH}$ levels (Figure VI-1), which is indicative of the regional unfformity of acidification. Estimared actdiflcallui levels are significantly correlated with sulfate levels (Figure VI-2), indicating that atmospheric strong acid $\left(\mathrm{H}_{2} \mathrm{SO}_{4}\right)$ inputs are the primary source of acidification.

The third approach lo estiuting acidification was to directly compare historical (1930's data) and current (1975) alkalinity measurements. Alkalinity measurements obtained in the 1930's for Adirondack lakes employed methyl orange indicator for end point determination in the titration of water samples for total alkalinity measurment. This method yields an apparent end point pH of approximately 4.4, which over-estimates the true alkalinity (as measured by Gran plot location of the titration curve inflection for the 1975 data) by the amount of free $\mathrm{H}^{+}$ions present in solution at this $\mathrm{pH}$ level $\left(40 \mu \mathrm{eq} / \mathrm{l} \mathrm{H}^{+}\right)$. 
The 1930's alkalinily measurements were corrected to correspond to true alkalinity levels by subtracting $40 \mu \mathrm{eq} / \ell$ from each value. Acidification was then estimated as the difference between corrected 1930's alkalinity levels and 1975 alkalinity measurements. The mean acidification for 36 Adirondack lakes, where data were avallable from both periods, was $104.7 \mu \mathrm{eq} / 1$ (SD 50.9). Estimated acidification for the same lakes, using the calcium-alkalinity model (equation 2), was $105.7 \mu \mathrm{eq} / 1$ (SD 31.8 ) which is not significantly different from the previous estimate ( $p .01)$.

2. Lake Classification. Lakes were classified into three categories, which define acidification and fish population status as discussed previously, utilizing regional acidification estimates and lake calcium concentrations. Henriksen 53 constructed a nomogram by grouping data from 719 lakes in southern Norway into discrete $\mathrm{pH}$ classes and then determined the least-squares regressions of calcium on acidification for each class. The resulting nomograph (Figure VI-3) can then be used to predict lake $\mathrm{pH}$ (and fish population status) from lake calcium levels and efther regional acidification or precipitation $\mathrm{pH}$. The two regression lines derived from the Norwegian lake data define the boundaries for the three classifications:

$$
\begin{array}{ll}
\mathrm{HCO}_{3} \text { lake boundary } & \mathrm{Ca}(\text { Heq } / \ell)=49.9(.28+.0192 \mathrm{Ac}-\mathrm{S}) \\
\text { Acid lake boundary } & \mathrm{Ca}(\text { Heq } / \ell)=49.9(.07+.0139 \mathrm{Ac}-\mathrm{S})
\end{array}
$$

The characteristics, expected $\mathrm{pH}$ levels, and boundary calcium levels for this classification, as applied to the Adirondack data are given in Table VI-1.

The observed pH levels for lakes classified as described below are illustrated in Figure VI-3. For the Adirondack data, $70 \%$ of the lakes were correctly classified and $98 \%$ of the ELA lakes were correctly designated as $\mathrm{HCO}^{3}$ lakes. These results are similar to those obtained by Henriksen 53 for classification of lakes in southern Norway. An additional test of the validity of this model for predicting lake $\mathrm{pH}$ changes resulting from acidification is illustrated in Figure VI-4. Increase in $\mathrm{H}^{+}$concentration between the 1930's and 1975, as determined from differences in $\mathrm{pH}$, were compared to calcium concentrations measured in 1975 for 36 Adirondack lakes. The break in the plot of $\mathrm{H}^{+}$against calcium occurs precisely at the calcium level predicted from equation (4). The results of these model predictions for Adirondack and ELA lake data appear to be quite adequate for determining acidification status.

Fish population status in the Adirondack lakes is presented in Table VI-2. The frequencies of lakes not supporting fish life in each of the three lake classifications are comparable to those reported by Henriksen 53 for lakes in southern Norway. The lakes of the ELA are still predominantly pristine, $\mathrm{HCO}_{3}$ type waters and the fish populations are unaffected. 9 
Table VI-1

Lake Classification for Adirondack Mountain lakes, based on the nomograph of Henriksen. 53

\begin{tabular}{|c|c|c|c|}
\hline $\begin{array}{l}\text { Lake } \\
\text { class }\end{array}$ & Expected pll & Fish Population & $\begin{array}{r}\text { Boundary } \mathrm{Ca} \mu \mathrm{eq} / \mathrm{e} \\
\text { (Adirondack) }\end{array}$ \\
\hline $\mathrm{ICO}_{3}$ & .7 .3 & Goud & $>110$ \\
\hline Transitional & $4 \cdot 7-5.3$ & Sparse & $73-110$ \\
\hline AcId & $<4.7$ & Barren & $<73$ \\
\hline
\end{tabular}

\section{Table VI-2}

Fish population status in 214 Adirondack Mountain lakes, Elassiffed according to the nonograph of Figure VT-3.

\begin{tabular}{|c|c|c|c|}
\hline Lake Type & $\mathrm{HCO}_{3}$ & Trans & Acid \\
\hline Fippeted pII & $>5.3$ & $4 \cdot 7-5.3$ & $<4.7$ \\
\hline Number of lakes & 69 & 97 & 48 \\
\hline 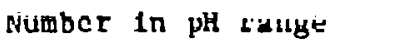 & 61 & 65 & 27 \\
\hline$\%$ correctly classified & 88.4 & 67.0 & 56.3 \\
\hline$\%$ without fish & 2.9 & 54.6 & 91.7 \\
\hline
\end{tabular}




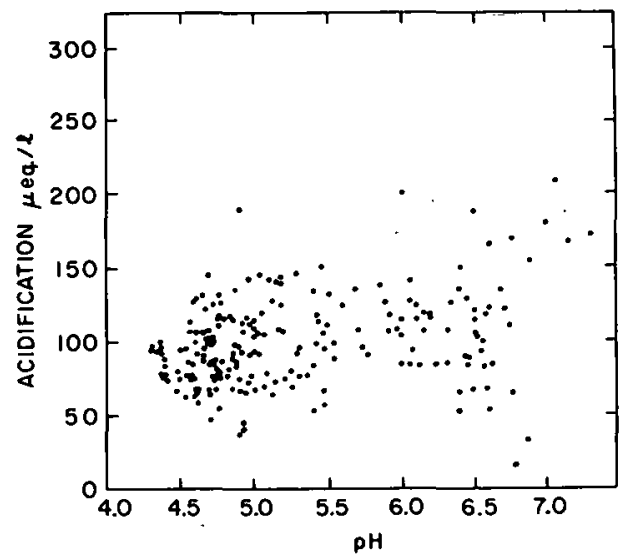

Figure VI-1. Acidification of Adirondack Lakes in Relation to $\mathrm{pH}$ measured in 1975 (215 Lakes). Mean Acidification $=99.6 \mu \mathrm{eq} \ell$, $\mathrm{SD}=30.6$, Where Acidification $\mu \mathrm{eq} / \ell=1.42(\mathrm{Ca} \mu \mathrm{eq} / \ell)-32$

(ALK $\mu$ eq/l)

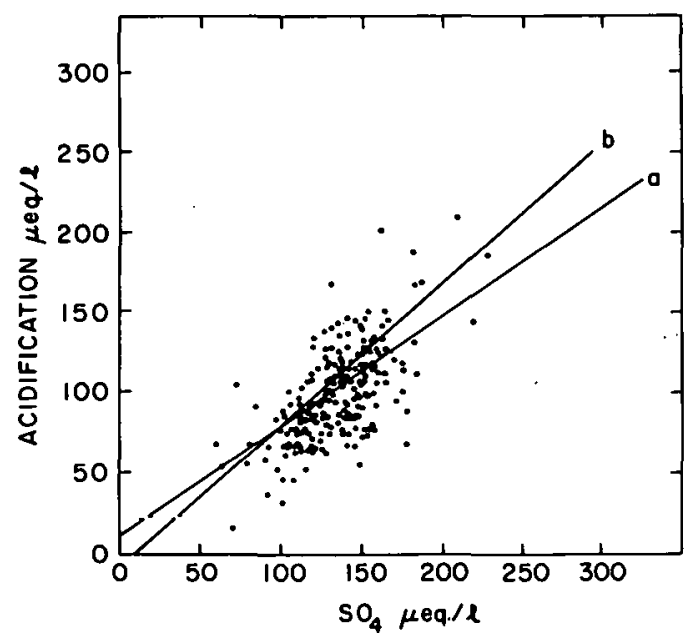

Figure VI-2. Acidification of Adirondack Lakes in Relation to $\mathrm{SO}_{4}$ measured in 1975 (215 Lakes). Regression:

(a) Acidification $=0.676\left(\mathrm{SO}_{4} \mu \mathrm{eq} / \mathrm{l}\right)$

$+10($ data $)(r=0.62, p<.01)$;

(b) AcIdtfication $=0.89$ (exe. $\left.\mathrm{SU}_{4} \mu \mathrm{eq} / l\right)-12$. Henriksen 1979.51 

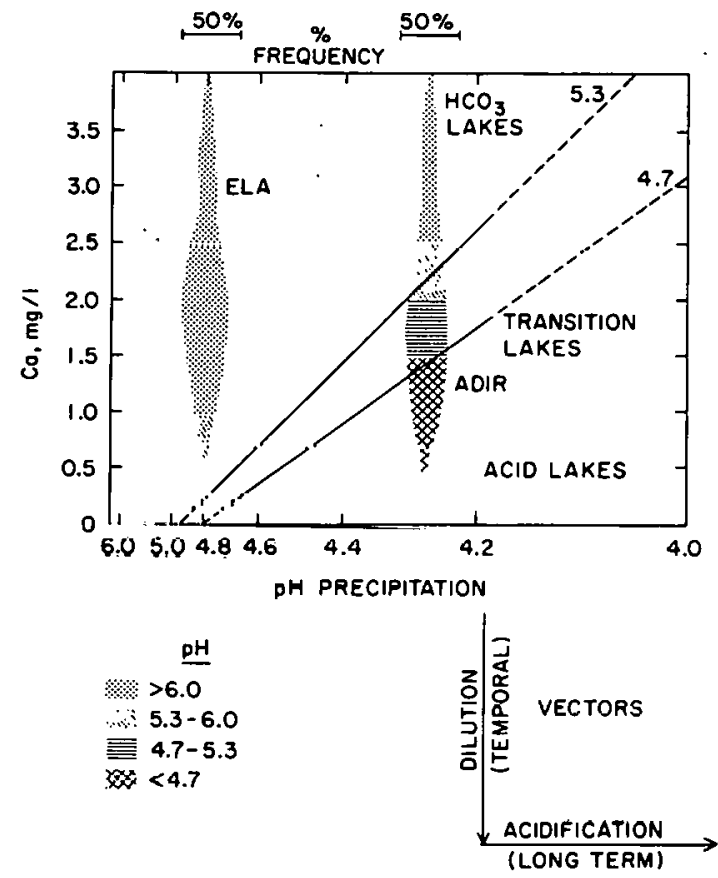

Figure VI-3. Nomograph for Predicting Lake $\mathrm{pH}$ and Fish Population Status From Lake Ca Levels and Either Regional Acidification or Precipitation pH. Regression Lines for the Boundary Between $\mathrm{HCO}_{3}{ }^{-}$and Transition Lakes, are Given $1 \mathrm{n}$ the Text as Eyuations (4) and (5) Reopcctively

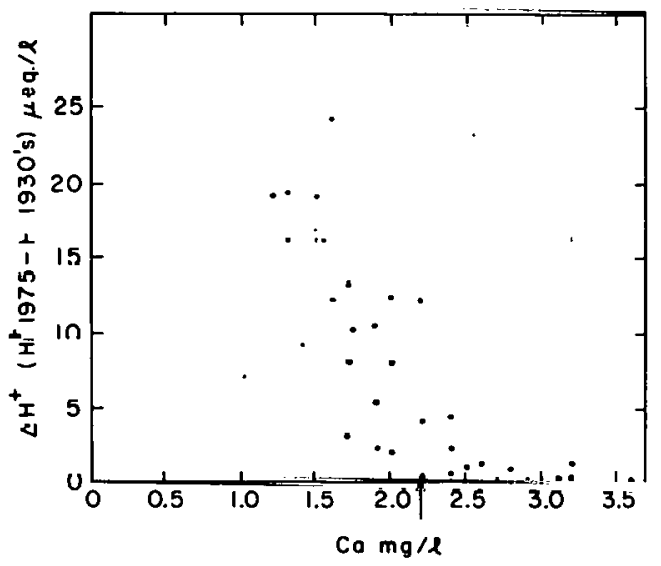

Figure VI-4. Changes in $\mathrm{H}^{+}$Concentration in 36 Adirondack Lakes Frum the 1930's to 1975, in Relation to Ca Levels Measured in 1975. The Arrow Designates the Critical Ca Level for Loss of $\mathrm{HCO}_{3}{ }^{-}$Buffering, as Predicted From Henriksen's 53 model for a Region Exposed to Precipitation With a Weighted Mean $\mathrm{pH}$ of 4.26 


\section{REFERENCES}

1. Almer, B., W. Dickson, C. Ekstrom, E. Hornstrom, and U. Miller. 1974. Effects of acidification of Swedish lakes. Ambio 3:330-336.

2. Almer, B., W. Dickson, C. Ekstrom, and E. Hornstrom. 1978. In Sulfur in the Environment, part 2, (ed. Nriagu,.J. 0.) 272-311 (Wiley, New York).

3. American Public Health Association. 1971. Standard Methods for the Examination of Water and Wastewater. Thirteenth ed. APHA. Washington, D.C.

4. Andersson, I., O. Grahn, H. Hultberg, and L. Landner. 1974. Jamforande undersokning av olika tekniker for alterstallande av forsurade sjoar. Institute for Water and Air Research, Stockholm, STU Report 73-3651.

5. Anonymous. 1979. Soil Survey of Augusta County, Virginia. U.S.D.A. Soil Conservation Service and Forest Service.

6. Barnes, R. S., D. E. Spyridak1s, and P. B. Birch. 1979. Atmospheric input of trace metals to lake sediments in western Washington State (abs.): Am. Chem. Soc. Annual Meeting, Environ. Div.

7. Bartholomew, M. J. 1978. Geology of the Greenfteld and Sherando Quadrangles, Virginia. Virginia Department of Mineral Resources Publication 4 .

8. Beamish, R. J., and H. H. Harvey. 1972. Jour. Fish Res. Board Can. 29, 1131-1143.

9. Beamish, R.S., Bloues, L.M., and G.A. MacFarlane, Tech. Rep. No. 607, Dept. of Env., Fish \& Mar. Serv. Canada (1976).

10. Beck, K.C., Router, J.A., and E.M. Perdue, Geochem. et. Cosmochem., $38: 344$ (1974).

11. Be11, H. L. 1971. Effect of low $\mathrm{pH}$ on the survival and emergence of aquatic insects. Water Res. 5:313-319.

12. Bick, H. and E. F. Drews. 1973. Selbstrelnigung und Ciliatenbesledlung in saurem Milieu (Modellversuche). Hydrobiologia 42(4):393-402.

13. Boling, R. H., Jr., E. D. Goodman, J. A. VanSickle, J. O. Zimmer, K. W. Cummins, R. C. Petersen, and S. R. Re1ce. 1975. Toward a model of detritus processing in a woodland stream. Ecology 56:141-151.

14. Borgström, R., J. Brittain, and A. Lillehammer. 1976. Evertebrater og surt vann: oversikt over innsamlingslokaliteter. ENSF Ir 21/76. SNSF Project, 1432 Aas-NLH, Norway.

15. Borgstrom, R. and G. R. Hendrey. 1976. $\mathrm{pH}$ tolerance of the first larval stages of Lepidurus arcticus (Palas) and adult Gammarus Lacustris G. 0. Sars. SNSF IR 22/76. SNSF Project, 1432 Aas-NLH, Norway. 
16. Cogbill, C. V. and G. E. Likens. 1974. Precipitation in the northeastern United States: Water Resources Research, 10, p. 1133-1137.

17. Cole, J. J. and G. E. Likens. 1978. Measurement of mineralization of phytoplankton detritus in an oligotrophic lake. Manuscript in press.

18. Conroy, N., K. Hawley, W. Keller, and C. LaFrance. 1975. Influences of the atmosphere on lakes in the Sudbury area. J. Great Lakes Res. 2 supp1. 1 (1976): 146-165.

19. Cragin, J. H., M. M. Herron, and C. C. Langway, Jr. 1975. The chemistry of 700 years of preclpitation at Dye 3, Greenland: CRREL Research Report \#341, $18 \mathrm{p}$.

20. Cummins, K. W, 1973. Trophic relations of aquatic insects. Ann. Rev. Entomol. 18:183-206.

21. Da1y, L.M., DJ Completion Report F-20-R-2, Mass. Fish and Game Dept. (1965).

22. Davis, R. B., S. A. Norton, and D. F. Brakke. 1979. Heavy metal deposition in bottom sediments and acidification of New England lakes from atmospheric inputs, and the effect on lake biota (abs.): Conf. on Great Lakes Res.

23. Davis, R. O., M. O. Smith, J. H. Bailey, and S. A. Norton. Acidification of Maine Lakes by Acidic Precipitation, Verh. Intern. Verein. Limnol., $20: 532-537$.

24. Deevey, E.S. and J.3. Dishop, Bull. No. 63, Conn. State Bd. Fish and Game, (1942).

25. Dills, C. and D. T. Rogers. 1974. Macroinvertebrate commun1ty struclure as an indicator of acid mine pollution. Environ. Pollut. 6:239-262.

26. Dinsmore, B. H. 1968. The aquatic ecology of Toms Run, Clarion County, Pennsylvania Preceding watershed reclamation, Pensylvania Dept. of Heal th, Bureau of Sanitary Engineering, Div. of Water Quality Publ. No. 21. Health, Bureau of Sanitary Engineering, Div. of Water quality Publ. No. 21 .

27. Dochinger, L. S., and T. A. Sellga (eds.). 1976 proceedings of the First International Symposium on Acid Precipitation and the Forested Ecosystem. U.S.D.A. Forest Service General Technical Rcport NE-23.

28. Edgerton, E. personal communication.

29. Fogg, G. E. 1977. Excretion of organic matter by phytoplankton. Limno1. Oceanogr. 22:576-577.

30. Frey, D.G., J. Elisha Mitch. Soc., 65:1 (1949).

31. Frey, D.G. J. Elisha Mitch. Soc., 67:1 (1951). 
32. Galloway, J. N. and G. E. Likens. 1976. Calibration of Collection Procedures for the Determination of Precipitation Chemistry. Water, Air, and Soil Pollution 6:241.

33. Galloway, J. N. and E. B. Cowling. 1978. The Effects of Precipitation on Aquatic and Terrestrial Ecosystems: A Proposed Precipitation Chemistry Network. APCA Journal. 28(3):229.

34. Galloway, J. N. 1979. Unpublished data.

35. Gasith, A. and A. D. Hasler. 1976. Airborne litterfall as a source of organic matter in lakes. Limnol. Oceanogr. 21:253-258.

36. Gathright II, T. M. 1976. Geology of the Shenandoah National Park. Virginia Department of Mineral Resources Bulletin 86.

37. Grahn, 0., H. Hultberg, and L. Landner. 1974. Oligotrophication--a self-accelerating process in lakes subjected to excessive supply of acid substances. Ambio 3:93-94.

38. Grahn, 0. 1975. Macrophtye succession in Swedish Lakes caused by deposition of airborne acid substances. In Proc. First Intl. Symp. Acid Precipitation and the Forest Ecosystem, Ohio State Univ., 12-15 May 1975. USDA Forest Service Gen. Tech. Report NE-23, 1976, pp 519-530.

39. Guthrie, R.C., Stolgitis, J.A., and W.L. Bridges, Fish Rep. No. 1., Rhode Is1. Dept. Nat. Res., (1973).

40. Guthrie, R.C. and H.A. Stolgitis, Fish Rep. No. 3, Rhode Is1. Dept. Nat. Res., (1977).

41. Hagen, A. and A. Langeland. 1973. Polluted snow in southern Norway and the effect of the melt water on freshwater and aquatic organisms.

Environ. Pollut. 5(1):45-57.

42. Hagström, T. 1977. Grodornas Försvinnande 1 en Försurad sjö (The disappearance of frogs in an acidified lake). Sveriges Natur $11 / 77: 367-369$.

43. Hall, R. J., G. E. Likens, S. Fiance, and G. Hendrey. 1980. Experimental stream acidification in the Hubbard Brook Experimental Forest. Accepted for publication in Ecology.

44. Harrison, A. D. 1958. The effects of sulphuric acid pollution on the biology of streams in the Transvaal, South Africa. Verh. Internat. Ver. Limno1. 13:603-610.

45. Harrison, A. D. and J. D. Agnew. 1962. The distribution of invertebrates endemic to acid streams in the Western and Southern Cape Province. Ann. Cape Prov. Mus . 2:273-291.

46. Hellebust, J. A. 1974. Extracellular products. In W. D. Stewart (ed.) Algal physiology and biochemistry, Univ. Calif. 
47. Hendrey, G. R. and R. F. Wright. 1975. Acid precipitation in Norway: Effects on aquatic fauna. In Proc. First Specialty Sump. Atmospheric Contrib. Chem. Lake Waters, Inter. Assoc. Great Lakes Res., Orillia, Ontario, 28 Sept.-1 Oct. 1975. J. Great Lakes Res. 2 supp1. 1:192-207.

48. Hendrey, G. R. 1976. Effects of low pH on the growth of periphytic algae in artificial stream channels. SNSF Project, 1432 Aas-NLH, Norway.

49. Hendrey, G. R., K. Baalsrud, T. Traaen, M. Laake, and G. Raddum. 1976. Acid precipitation: some hydrobiological changes. Ambio 5:224-227.

50. Henriksen, A. and R. F. Wright. 1976. Concentrations of heavy metals in small Norwegian lakes. SNSF Project Report. SNSF Project, 1432 Aas-NLH, Norway.

31. Hellutksen, A. 1979. A Simple Apprnash for Idenillyluy and Meaourlug Acidification of Freshwater. Nature vol. 278.

32. Henrlkseu, A., Naturc, 278:5112 (1979a)

53. Henriksen, A., pers. comm. manuscript in preparation.

54. Herricks, E. E. and J. Cairns, Jr. 1974. Rehabilitation of streams receiving acid mine drainage. Bull. 66, Virginia Water Resources Research Center, V.P.I., Blacksburg, Va. 24061.

55. Hultberg, H. 1975. Thermally stratified acld water in lake winter--a key factor inducing self-accelerating processes which increase acidification. In Proc. First Intl. Symp. Acid Precipitation and the Forest Licosystem, Ohlu State Univ., 12-15 May 1975. IISDA Forest Service Gen. Tech. Rep. NE-23, 1976.

56. Johannessen, M., T. Dale, E. Gjessing, A. Henriksen, and R. F. Wright, 1975. Acid precipitation in Norway: the reglunal distribution of contaminants in snow and the chemical concentration processes during snowmelt. Proc. Int1. Symp. Isotopes and Impurities in Snow and Ice, Int1. Assoc. Hydrolog. Sci., Grenoble, France, Aug. 1975. SNSF FA 4/75, SNSF Profert., 1432 Aas-NLH, Norway.

57. Johnson, A. J. 1979. Acidiftration of Headwater Streams in the New Jersey Pine Barrens, Journal of Environmental Quality, vol. 3. In press.

58. Johnson, M. G., M. F. P. Michalski, and A. E. Christie. 1970. Effects of acid mine wasces on phytoplankton communities of two northern Ontario Lakes. J. Fish. Ree. Bd. Canada 2.7 (3)425-444.

59. Johnson, N. M. 1979. Acid Rain: Neutralization within the Hubbard Brook Ecosystem and Regional Implications. Science. 204:497.

60. Jordan, M. and G. E. Likens, 1975. An organic carbon budget for olfgotrophic lake in New Hampshire, USA. Verh. Internat. Vere1n, Litatiol. 19:994-1003. 
61. Keroher, G. C. et al. 1966. Lexicon of geologic names of the United States for 1936-1960. Parts 1, 2, and 3: U.S. Geol. Survey Bu11. 1200.

62. Keroher, G. C. et al. 1970. Lexicon of geologic names of the United States for 1961-1967. U.S. Geol. Survey Bull. 1350.

63. King, D. L. 1970. The role of carbon in eutrophication. J. Water Pollution Control Fed. 42:2035-2051.

64. Kramer, J. R. 1976. Geochemical and 1ithological factors in acid precipitation (in) Proceedings of the First International symposium on acid precipitation and the forest ecosystem: U.S. Dept. Agric. Forest Service Gen. Tech. Rept. NE-23, p. 611-618.

65. Kwiatkowski, R. E. and J. C. Roff. 1976. Effects of acidity on the phytoplankton and primary productivity of selected northern Ontario lakes. Can. J. Botany 54:2546-2561.

66. Laake, M. 1976. Effekter av lav pH pa produks jon, nedbrytning og stoffkretslop 1 litteralsoner. SNSF-Project, 1432 Aas-NLH, Norway.

67. Lazarus, A. C., Elizabeth Lorange, and J. P. Lodge, Jr. 1970. Lead and other metal ions in United States Precipitation: Envir. Sc. and Tech., 4, p. 55-58.

68. Leivestad, H., G. Hendrey, I. P. Muniz and E. Snekvik. 1976. pp. 87-111 in: Impact of Acid Precipitation on Forest and Freshwater Ecosystems in Norway (Sumnary Report, Phase I of SNSF project).

69. Likens, G. E. 1976. Acid Precipltation, Chem. Eng. News 54:29.

70. Likens, G. E., F. H. Bormann, R. S. Plerce, J. S. Eaton, and N. M. Johnson. 1977. Biogeochemistry of a Forested Ecosystem.

Springer-Verlag, New York.

71. Likens, G. E., R. F. Wright, J. N. Galloway and T. J. Butler. 1979. Ac1d Ra1n. Sc1 Am. 241(4):43-51.

72. Liljestrand, H. M. and J. J. Morgan. 1979. Acidic precipitation in southern California (abs.): Am. Chem. Soc. Annual Meeting, Environ. Div.

73. Malmer, N. SNV Res. Rep. No. PM 402E, Univ. Lund, Sweden, (1975).

74. McFee, W. W. 1979 Sensitivity of soil regions to long term acid precipitation. EPA. Decision Series Publication (in press).

75. Mills, A. 1979. Department of Environmental Sciences, University of Virginia, Charlottesville, VA. Personal Communication. 
76. Moss, B. 1973. The influence of environmental factors on the distribution of freshwater algae: an experimental study, II. The role of $\mathrm{pH}$ and the carbon dioxide bicarbonate system. J. Ecol. 61:157-177.

77. National Academy of Sciences. 1978, Sulfur Oxides.

78. National Atmospheric Deposition Program. 1979. NADP First data report: July 1978 through February 1979: Natural Resource Ecology Laboratory, Colorado State University.

79. Norvell, W.A. and C.R. Frink, Bull. No. 759, Conn. Agric. Exp. Sta., New Haven (1975).

80. Oden, S. 1976. The acidity problem - an outline of concept. Water, $\Delta i r$, and Soll. Pollution, 6:137-166.

81. Ukland, J. 1969. Distribution and ecology of the freshwater snails (Gastropoda) of Norway. Malacologia 9:143-151.

82. Økland, K. A. 1969. On the distribution and ecology of Gammarus.. lacustris G. 0 . Sars in Norway, with notes on its morphology and biology. Norweg. J. Zool. 17:111.

83. Oliver, D. R. 1971. Life history of the Chironomidae. Ann. Rev. Entomo1. 16:211-229.

84. Parsons, J. D. 1968. The effects of acld strip-mine effluents on the ecology of a stream. Arch. Hydrobiol. 65(1):25-50.

85. Parsons, J. D. 1377. Effccte of acid mine wastes on aquatic ecosystems. Water, Air and Soil Pollut. 7:333-354.

06. Pough, F. H, 1976. Arid precipttation and embiyonic mortality of spotted salamanders, Ambystoma macularum. Sclence 192: 68-\%.

87. Rockingham County, Virginia, So11 Conservation Service. 1979. Unpublished data.

88. Saunders, G. W. and T. A. Storch, 1971. Coupled oscillatory cunlrul mechanism in a planktunte system. Nature 230:58-6n.

89. Schelder, W., J. Adamsk1, and M. Paylor. 1975. Reclamation acidified lakes near Sudbury, Ontario. Ontarto Ministry of the Environment, Texdale, Oncarto, Caliada.

90. Schofield, C. L. 1975. p. 477 in Proc. First Internat. Symp. on Acid Precipitation and the Forest Ecosystem. USDA Forest Service Gen. Tech. Report NE-23.

91. Schofleld, C. L. 1976. Acid Prectpitation: Effects on Fish. Ambio. $5(5-6): 228$.

92. Schofield, C. L. 1979. Acidification impacts on fish populations (abs.): Am. Chem. Soc. Annual Meeting, Environ. Div. 
93. Schaffer and Galloway. Inpublished data, to be presented as a MS thcsis. Department of Environmental Sciences, University of Virginia.

94. Sprules, G. W. 1975. Midsummer crustacean zooplankton communities in acid-stressed lakes. J. Fish. Res. Bd. Canada 32:389-395.

95. Sutcliffe, D. W. and T. R. Carrick. 1973. Studies on mountain streams in the English lake district I. pH, calcium and the distribution of invertebrates in the River Duddon. Freshwater Biol. 3:437-462.

96. Watt, W. D., D. Scott, and S. Ray. 1979. Acidification and other chemical changes in Halifax County lakes after 21 years.

Limno1. Oceanogr. 24: 1154-1161.

97. Werner, J.'J. 1966. Geology of the Vesuvius Quadrangle, Virginia. Virginia Department of Mineral Resources Report of Investigations \#7.

98. Wetze1, R. G. 1975. Limnology. W. B. Saunders Co. 743 pp.

99. Wiebe, W. J. and D. F. Smith. 1977. Direct measurement of dissolved organic carbon release by phytoplankton and incorporation by microheterotrophs. Mar. Biol. 42:213-223.

100. Wiklander, L., EPRI Rep. No. SOA77-403, (1979).

101. Winkler, E. M. 1976. Natural Dust and Acid Rain. pp. 209-217 in Ref. 1 .

102. Wojcik, B. and L. Butler. 1977. Aquatic insects as indicators of stream environmental quality in northern West Virginia. Bull. 653T. West Virginia Agricultural and Forestry Experiment Station, Morgantown, West Virginia.

103. Wright, R.F. and E. Snekvik, Verb. Internat. Verein. Limnol. 20:765 (1979).

104. Wright, R.F., and E. T. Gjessing. 1976. Changes in the Chemical Compostion of Lakes. Ambio 5(5-6):219.

105. Zimmerman, A. P. and H. H. Harvey. 1979. Sensitivity to acidification of waters of Ontario and neighboring states: Final report for Ontario Hydro. Univ. Toronto, Ontario. $48 \mathrm{pp}$. 


\section{APPENDIX-I}

Water Quality Maps for States of the Eastern U.S.

The maps presented here are based on data in the Acidification Chemistry Information Database (ACID). About half of the currently avallable data which the authors have located is in ACID.

Station locations are shown in the maps of average $\mathrm{pH}$ and/or alkalinity. Data has also been organized on a county-by-county basis, which reflects (a) the minimum alkalinity value observed in each county and (b) the average of all station values, In the perlod 19\%b-1979. The minimum value ulap constitutes a gross-scale sensitive areas map.

The following states are included as of January 1980: Connecticut, Delaware, Georgia, Kentucky, Maryland, Massachusetts, Mlinesota, New llampshire, New Jersey, New York, North Carolina, Rhode Island, South Carolina, Tennessee, Vermont, Virginia, West Virginia and Wisconsin. 
APPENDIX-II

Sources of Water Chemistry Data

$9 / 28 / 79$

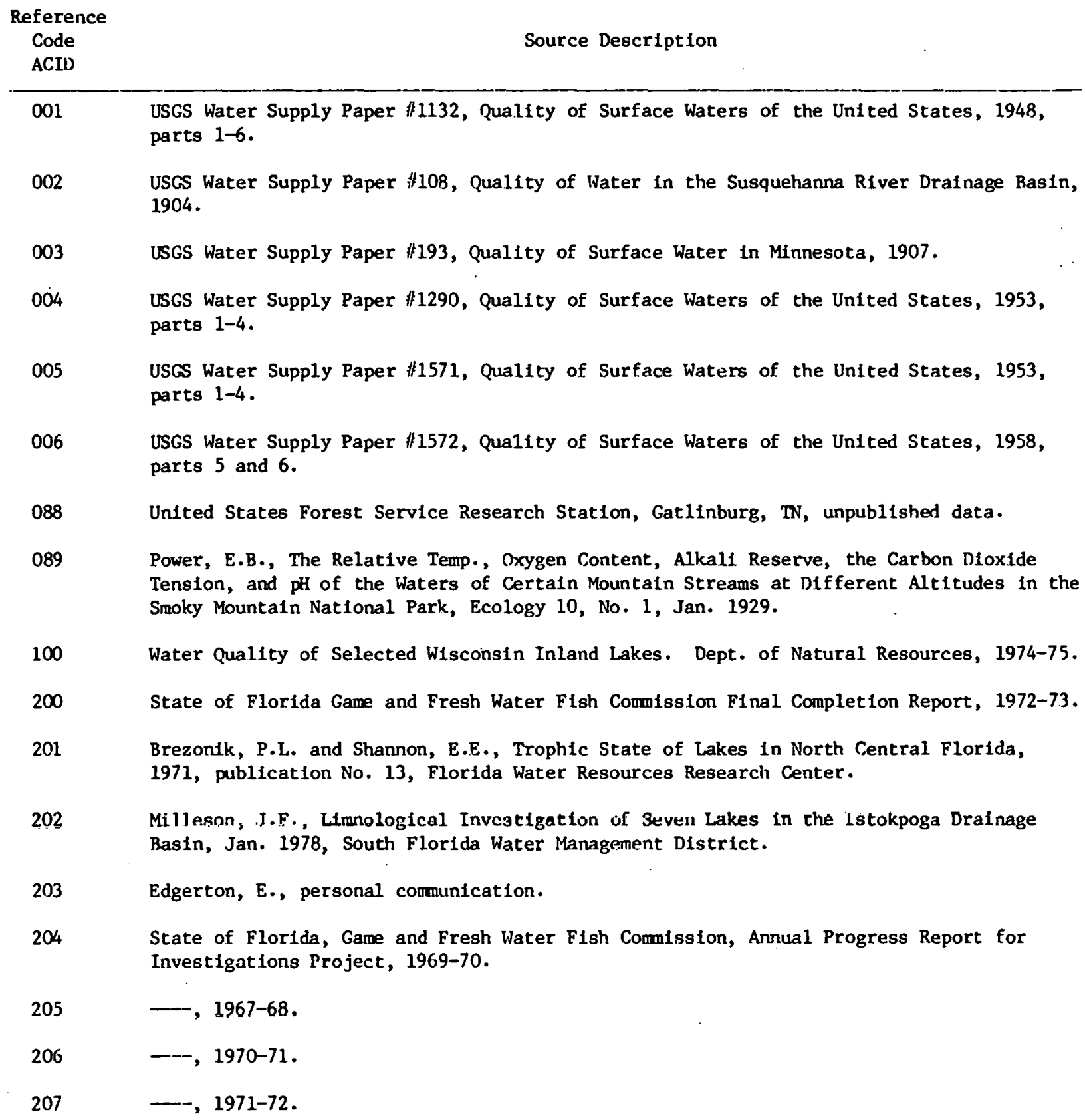




\begin{tabular}{|c|c|}
\hline $\begin{array}{l}\text { Reference } \\
\text { Code } \\
\text { ACID }\end{array}$ & $\begin{array}{l}\text { APPENDIX-II (Continued) } \\
\text { Source Description }\end{array}$ \\
\hline 352 & Feb. 1976. \\
\hline 400 & $\begin{array}{l}\text { Water Qual1ty Monitoring Program on Representative F1sh Lakes 1973, MN Dept, of Natural } \\
\text { Resources, Div. of Fish and Wildlife, Environment Sectlon, Investigational Report No. } \\
\text { 350, June 1974. }\end{array}$ \\
\hline 401 & --, 1974, Invest.tgational Report No. 351, Jan. 1975. \\
\hline 402 & -, 1975, Investigational Report No. 352. \\
\hline 403 & -_, 1976, Invest1gational Report No. 353, March 1977. \\
\hline 404 & --, 1977, Investigational Report No. 354, April 1978. \\
\hline 405 & --, 1978, Invest1gational Report No. 361, February 1979. \\
\hline 500 & $\begin{array}{l}\text { Water Quality Seminar and Stream Surveys 1976-78, Pennsylvania, State Counc1 } 1 \text { Trout } \\
\text { Un].imited. }\end{array}$ \\
\hline 501 & $\begin{array}{l}\text { Jewel1, M.E., and Brown, H.W., "The Fishes of an Actd Lake," Trans. of Amer. } \\
\text { Microscoplcal Soclety, April 1924. }\end{array}$ \\
\hline 600 & $\begin{array}{l}\text { Daly, Leo M., "Analysis of Water Chemistry," Job Completion Report Research Project } \\
\text { Segment, Project \#F-20-R-2, Massachusetts Division of F1sh and Game. }\end{array}$ \\
\hline 601 & $\begin{array}{l}\text { Norvel1, W.F., and C.K. Frink, "Water Chemistry of } 23 \text { Connecticut Lakes," Connecticut } \\
\text { Agricultural Experimental Station, New Haven, CT, Bulletin } 759 .\end{array}$ \\
\hline 602 & Thurrh, Tnm, Untyersity of Delaware, Newark, Delaware, pcroonal comountcat $1 \mathrm{mn}, 5 / 11 / 79$. \\
\hline 603 & $\begin{array}{l}\text { Guthrle, R., I. Stolgitis, W.L. Bridges, Pawcatuk River Watershed, Fisherles Management } \\
\text { Survey, Rhode Island Vivision of Fish and W1ldlife, Fisherles Report No. 1, July } 1973 .\end{array}$ \\
\hline 604 & $\begin{array}{l}\text { Guthrie, R., J.A. Stolgitis, "Fisheries Investigations and Management in Rhode Island } \\
\text { Lakes and Ponds," Rhode Island Division of Fish and Wildlife, Fisherles Report No. 3, } \\
\text { February } 1977 .\end{array}$ \\
\hline 605 & $\begin{array}{l}\text { Guthrie, R., "Moosup River Watershed Survey, Rhode Island Div. of Fish and Wildlife, } \\
\text { Sumer 1973. }\end{array}$ \\
\hline 606 & $-m, 1977$, "Hunt. RIver Watershed Survey," R.I. Div. of IIsh and Wildlife. \\
\hline 607 & --, 1977, "Saugatucket River Waterohed Survuy," R.T. niv, of Fioh and Wildlife. \\
\hline 608 & --, 1975, "Blackstone River Watershed Survey," R.I. D1v. of Fish and Wildlife. \\
\hline 609 & $\begin{array}{l}\text { Glass, G.E., et al., "Impact of Alr Pollutants on Wilderness Areas of Northeastern } \\
\text { Minnesota," E.P.A. Draft, November } 1978 \text {. }\end{array}$ \\
\hline 610 & $\begin{array}{l}\text {-_, 1976, "Algae Control by Mixing, Kezar Lake, Sutton, H.H.," N.H. Water Supply and } \\
\text { Pollution Control, August } 1976 .\end{array}$ \\
\hline
\end{tabular}




\begin{tabular}{|c|c|}
\hline $\begin{array}{l}\text { Reference } \\
\text { Code } \\
\text { ACID }\end{array}$ & $\begin{array}{l}\text { APPENDIX-II (Continued) } \\
\text { Source Description }\end{array}$ \\
\hline 611 & Trout, Spring $1974,15(2): 25-28$. \\
\hline 612 & Nestor, Ernie, P.0. Box 235, Alloy, WV 250n2, personal communtcation. \\
\hline 613 & Data Collected by Water Supply and Pollution Control Comnlsston, Concord, N.H. \\
\hline 614 & West Virginta Fish and Game Division Report D.J. F-12-R-6, 1969. \\
\hline 615 & $\begin{array}{l}\text {-1972, Water Quality Monitoring Data for Georgia Streams, Georgla Dept. Natural } \\
\text { Resources, Environmental Protection Division. }\end{array}$ \\
\hline 616 & $\begin{array}{l}\text { - 1976, Water Quality Monitoring Data for Georgla Streams, Georgia Dept. Natural } \\
\text { Resources, Environmental Protection Division. }\end{array}$ \\
\hline 617 & $\begin{array}{l}\text {-- 1975, Water Quality Monttoring Data for Georgia Streams, Georgia Dept. Natural } \\
\text { Resources, Environmental Protection Division. }\end{array}$ \\
\hline 618 & N.H. Water Supply and Pollution Control Monitoring Data, obtalned from N.H. office. \\
\hline 619 & $\begin{array}{l}\text { D.J. Reports from Fish and Game offices; Maryland, F-8-R-I, Kentucky, F-14-R-2, New } \\
\text { Jersey, F-20-R, F-20-R-5, F-23-R-2. }\end{array}$ \\
\hline 620 & Carl Schofleld's Adirondack Lake Data, same reference as Fish Data. \\
\hline 623 & $\begin{array}{l}\text { D.J. Report from NJ F-20-R-7, "Investigations on the Mortality of Stocked Trout in N.J. } \\
\text { Streams." }\end{array}$ \\
\hline 624 & Georgla Data from GA Dept. Natural Resources, Environmental Protection Division. \\
\hline 625 & $\begin{array}{l}\text { North Carolina D.J. Job Completion Report, F-6-R and F-5-R, "Inventory of Fish } \\
\text { Population in Lentic Water," } \mathrm{NC} \text { Wildlife Resources Comnission, Raleigh, NC, January } \\
\text { 1961. }\end{array}$ \\
\hline 626 & $\begin{array}{l}\text { Messer, J.B., J.R. Davis, T.B. Cromwell, W.C. Carnes, 1965, Survey of North Carolina } \\
\text { Rivers, Division of Inland Fisheries, NC. }\end{array}$ \\
\hline 627 & - 1937-1939, Blological Survey of Lakes and Streams, N.H. Watersherls. \\
\hline 628 & New Hampshire fleld data, collected ourselves. \\
\hline 629 & - 1964, Florida D.J. Reports, F-6-R, from Florida Fish and Game. \\
\hline 630 & - Data from Massachusetts Division of Water Pollution Control. \\
\hline 640 & $\begin{array}{l}\text { Creaser, C.W., and Brown, H.W., "Kydrogen Ion Concentration of Brook Trout Waters of } \\
\text { Northern Lower Michigan, Er.n } 1 \text { ngy } 8 \text {, January } 1927 .\end{array}$ \\
\hline 650 & $\begin{array}{l}\text { Juday, C., Fred, E.B., and Wilson, F.C., "The Hydrogen Ion Concentration of Certatn } \\
\text { Wisconsin Lake Waters," Trans. of Amer. Microscopical Society, October } 1924 .\end{array}$ \\
\hline
\end{tabular}
Wisconsin Lake Waters," Trans. of Amer. Microscopical Society, October 1924. 


$\begin{array}{lc}\text { Referenec } & \text { APPENDIX-II (Continued) } \\ \text { Code } & \text { Source Description } \\ \text { ACID } & \end{array}$

700 Deevey, E.8., Limnolngiral Studies in Cümtecticut. Am. Jour. Sci., Vol 2.38, No. 10, October 1940.

701 Wood, L.W., "Limnology of Remote Lakes in the Adirondack Region of New York State whth Emphasis on Acidffication Problems, N.Y. State Department of Health, Environmental Health Report No. 4, April 1978.

703 Fuhs, G.W., "The Chenistry of Streams Tributary to Lake George, New Yuik, N.Y: Statc Dept. of Health, Environmental Health Report No. 1, September 1972.

704 Fuhs, G.W., and Olsen, R.A., "Acid Precipitation Effects on Drinking Water in the Adlrondack Mountains of New York State," State of New York Dept. of Health, Technical Momorandim, May 1979.

800 Monroe Reservoir, Indlana, Techntcal Report No. 87, Indiana Untv. Water Resources Research Center, March 1977.

801 Cowles, R.P., and Schwitalla, A.M., "The Hydrogen Ion Concentratiun uf a Creek, Ito Waterfall, Swamp, and Ponds, Ecology Vol. 4, No. 4, October 1973.

U.S. GOVERNMENT PRINTING OFFICE: 614-090-\$4 